\title{
E SE DEUS FOSSE MULHER? AJURICABA VIROU PÍTON E PÍTON VIROU PETÚNIA QUE VIROU AJURICABA*
}

\author{
Antonio Miguel \\ Elizabeth Gomes Souza \\ Carolina Tamayo
}

\section{Resumo}

O filme Ajuricaba, o rebelde da Amazônia ${ }^{1}$ (CALDEIRA, 1977), produzido pelo diretor brasileiro Oswaldo Caldeira, em 1977, narra a resistência organizada pelo líder indígena Ajuricaba - a quem os portugueses diziam ser dotado de poderes místicos de se metamorfosear em onça, peixes ou aves -, no início do século XVIII, ao empreendimento colonizador de expansão econômico-mercantilista da coroa portuguesa de sujeição e uso de corpos indígenas como mão de obra de trabalho escravo. A nação indígena dos manaós liderada por Ajuricaba habitava a região do Rio Negro bem antes da chegada do colonizador europeu em terras de Abya Yala, hoje conhecidas como América do Sul. Na língua nativa, a palavra manáo - que significa mãe dos deuses - deu origem ao nome atual do município de Manaus, capital do estado do Amazonas. Por sua vez, o filme de 2019 da cineasta macedônia feminista Teona Strugar Mitevska, intitulado "God Exists, Her Name Is Petrunya", traduzido para o português por "Deus é Mulher e Seu Nome é Petúnia" (MITEVSKA, 2019) ${ }^{2}$, tem como foco a prática tradicional cristã do pega-cruø, da qual participam exclusivamente homens, e que é repetida anualmente pela Igreja Ortodoxa Macedônia, no dia 19 de janeiro, feriado religioso nacional em que se comemora a Epifania de Jesus Cristo. Esta prática consiste em se atirar uma cruz de madeira na correnteza do rio Otinja - que divide a cidade de Shtip, situada na Macedônia do Norte, em duas regiões - pelo sacerdote do local, e o prêmio concedido ao homem que conseguir resgatá-la é a suposta promessa divina de que ele teria um ano inteiro de sorte e prosperidade. Porém, Petúnia, uma mulher de 32 anos, professora de história, solteira, desempregada e desencantada com a vida e com o seu futuro incerto, estando às margens do rio no momento do ritual, num ímpeto irrefletido e casual, mergulha no rio e resgata a cruz, passando a sofrer, daí em diante, por ter supostamente transgredido as regras do ritual, todo tipo de agressões, violências e ataques machistas, patriarcais, moralistas etc. por parte dos concorrentes masculinos participantes da prática e das autoridades policiais, jurídicas e eclesiásticas da cidade. O episódio narrado no filme de Mitevska ocorreu, de fato, no ano de 2014, e está baseado em documentação jornalística tornada pública em uma pequena nota incluída na seção "fatos diversos” que, mesmo com inexpressiva repercussão pública,

\footnotetext{
* DOI - 10.29388/978-65-86678-51-2-0-f.463-533

${ }^{1}$ Ficha Técnica do filme (CALDEIRA, 1977) - Direção: Oswaldo Caldeira. Roteiro: Oswaldo Caldeira e Almir Muniz. Elenco: Rinaldo Genes (Ajuricaba), Paulo Villaça (Belchior Mendes de Morais), Sura Berditchevsky, Nildo Parente, Emanuel Cavalcanti, Fregolente, Aurélio Michiles, Carlos Wilson, Amir Haddad, Maria Sílvia. Trilha sonora: Quinteto Villa Lobos. Ano: 1977. Gênero: drama. 105 minutos.

2 Ficha Técnica do filme (MITEVSKA, 2019) - Direção: Teona Strugar Mitevska. Duração: 100 minutos. Distribuidora no Brasil: Pandora Filmes. Ano 2019. Principais integrantes do elenco: Zorica Nusheva (Petúnia), Labina Mitevska (Jornalista Slavica), Stefan Vujisic (jovem policial Darko), Suad Begovski (pároco Kosta), Simeon Moni Damevski (policial-chefe Milan), Violeta Sapkovska (Vaska, mãe de Petúnia), Peter Mircevski (Stoyan, pai de Petúnia), Andrijana Kolevska (Blagica, amiga de Petúnia). Fonte: (https://www.imdb.com/title/tt8054608/?ref_=fn_al_tt_1).
} 
acabou motivando a demissão da única jornalista que o divulgou pela televisão. Segundo Martins (2019), o propósito que motivou Mitevska na realização do filme foi, então, o de denunciar o caráter machista da festa popular da Epifania de Jesus nos países ortodoxos. Tomando-se como ponto de partida esses dois jogos fílmicos de linguagem constituídos na forma de vida do cinema contemporâneo, e dando-se destaque, nesses jogos, às práticas tradicionais das duas comunidades a que esses filmes se referem - a comunidade indígena dos manaós e a comunidade católico-ortodoxa da cidade de Shtip -, o propósito deste capítulo é o de problematizar terapeuticamente modos como tais práticas tradicionais afetam diferentemente corpos que delas participam, quer valorizando-as e promovendoas, quer condenando-as e opondo-lhes resistência. Tal problematização terapêutica se realiza à luz das gramáticas tensionais de estranbamento mútuo que se constituem nas práticas de contato e de confronto que se estabelece entre humanos que integram comunidades constituídas mediante vínculos de pertencimento diversos (pertencimento étnico a formas de vida ameríndias, no caso da comunidade indígena dos manaós, e pertencimento religioso a formas de vida do cristianismo ortodoxo, no caso da comunidade masculina promotora da prática do pegacruz) e humanos vistos como e que se veem como estrangeiros a essas comunidades (os colonizadores portugueses em relação à comunidade dos manaós; e uma mulher, Petúnia, não adepta a religiões, em relação à comunidade masculina católico-ortodoxa promotora da prática do pega-cruz). Tais práticas de contato e de confronto são realizadas intencionalmente, no caso do estrangeiro colonizador português em relação à comunidade indígena dos manaós e, casualmente, no caso da 'estrangeira' Petúnia em relação à comunidade católico-ortodoxa masculina de sua cidade. No primeiro caso, as relações de contato e confronto que se estabeleceram entre estrangeiros portugueses e a comunidade indígena dos manaós são significadas no quadro mais amplo das relações tensionais que se estabeleceram entre colonizadores e povos colonizados, isto é, entre os propósitos econômicos, políticos e religiosos que orientaram o projeto colonizador europeu - e, particularmente, o português - em terras ameríndias da Abya Yala e as práticas de resistência que as nações ameríndias e, particularmente, a nação indígena dos manaós, sob a liderança política de Ajuricaba, opuseram a tal projeto. No segundo caso, as relações de contato e confronto que se estabeleceram entre a 'estrangeira' Petúnia e a comunidade católico-ortodoxa masculina são significadas no quadro das relações conflituosas casualmente produzidas que entre eles se estabeleceram devido à suposta transgressão, por parte de Petúnia, uma mulher, de uma das regras da gramática orientadora da prática tradicional religiosa do pega-cruz, qual seja, a de ser ela uma prática restrita a homens. No primeiro caso, o estrangeiro, ao se apossar ilegitimamente do território alheio orientado por propósitos alheios à comunidade local, é quem transgride as gramáticas das práticas comunitárias locais, hostilizando e produzindo intencionalmente conflitos, violência e guerra, o que leva os manaós a realizarem práticas de resistência. No segundo caso, é a 'estrangeira' quem realiza práticas de resistência, dado que, ainda que não intencionalmente, é ela quem produz o conflito, constituindo-se, por essa razão, no alvo intencional de preconceito, hostilidade e violência por parte da comunidade católico-ortodoxa masculina e das autoridades locais. Nos dois casos, as gramáticas tensionais de estranhamento mútuo que se constituem nas práticas de contato e de confronto adquirem o poder performativo mobilizador de afetos interpessoais $e$ intercomunitários diversos - ódio, amor, preconceito, violência, resignação, rebeldia, resistência, impotência, empoderamento, confiança, desconfiança, suborno, traição, 
empatia, acolhimento, assédio, repulsa, coragem, temor, esperança, cinismo, orgulho, dúvida, fé, hesitação, discriminação, exploração, submissão, revolta, vingança etc. -, bem como o poder performativo de gerar práticas intra e intercomunitárias diversas: práticas de persuasão; práticas de assédio sexual; práticas de conversão religiosa; práticas de controle, exploração e escravização de corpos; práticas de submissão voluntária; práticas de negociação; práticas de aprisionamento de corpos; práticas de resistência; práticas bélicas; práticas de constituição de si e do outro como "primitivo", "selvagem", "atrasado", "bárbaro", “inferior", "não-humano", "não-histórico", "frágil”, "feminino" etc. Em última instância, o poder performativo dessas gramáticas tensionais de estranbamento mútuo que se constituem nas práticas de contato e de confronto entre comunidades identitariamente constituídas e 'estrangeiros' que adentram os seus domínios assenta-se não propriamente no dogma escatológico por todos partilhado do caráter produtivo $e$ ambivalente dos fenômenos casuais e imprevisiveis - isto é, da crença na existência de divindades transcendentes dotadas de poderes proféticos ou divinatórios ambivalentes, delegados ou não a humanos ou a outros seres naturais, de protegerem suas comunidades contra todas as ameaças que possam desestabilizá-las e colocar em risco a preservação de sua unidade interna e identidade, ou então, de puní-las quando elas transgridem as suas recomendações, bem como de prognosticarem os seus destinos afastando-as de infortúnios ou levando-as ao caos e destruição -, mas sim, na diversidade de práticas cosmogônicas, místicas e religiosas, quer de matriz ameríndia, quer de matriz católico-ortodoxa, orientadas por crenças gramaticais distintas, conflitantes e irreconciliáveis. No caso das mitologias ameríndias, em suas aparições sempre imprevistas nas águas frias ou ferventes dos rios, o acaso se corporifica como mulher cujo corpo se transforma em corpos de animais, transformismo este que confunde, assombra e constitui o pesadelo do colonizador. Ainda que o foco de nossa investigação seja a problematização terapêutica dos modos como práticas tradicionais afetam diferentemente corpos que delas participam, é também nosso propósito problematizar, concomitantemente, as próprias gramáticas tensionais de estranbamento mútuo que se constituem nas práticas de contato e de confronto entre comunidades identitariamente constituídas e 'estrangeiros' que adentram os seus domínios, à luz do pensamento antropológico de Ludwig Wittgenstein, sobretudo em suas observações críticas à obra $O$ ramo dourado do antropólogo escocês James Frazer. Em relação à escrita imagético-textual segmentada que se segue, é preciso esclarecer os leitores de que ela não se constitui numa crítica cinematográfica ou numa análise fílmica comparativa que pretendesse esclarecer hermeneuticamente as intenções ou os sentidos que teriam supostamente orientado os diretores dos filmes na produção de suas obras cinematográficas. Nossa escrita segmentada também não poderia ser vista nem como uma narrativa historiográfica e nem como uma narrativa literária, uma vez que na distribuição sequencial numerada dos segmentos imagético-textuais que a compõem $(1,2,3, \ldots)$, não fomos movidos pelo propósito de costurá-los causalmente para se produzir teleologicamente um sentido ou para fechá-los com uma conclusão ou com a defesa de uma tese. Conexões semânticas possíveis se produzem de modo diverso, mediante investigação de semelhanças de família pertinentes entre jogos de linguagem envolvendo seis elementos simbólicos que perpassam simultaneamente as duas narrativas fílmicas aqui focalizadas: acasos; rios; cruzes; ouro/fortuna/abundância; paraísos com seus deuses; infernos com seus demônios e serpentes. Os esclarecimentos que fazemos de tais conexões 
não se manifestam ao longo do texto segmentado e numerado, mas nas notas de fim de texto a que cada um dos segmentos remetem. Tais notas se conectam biunivocamente mediante hiperlinks, de modo que ao clicar sobre qualquer região de um segmento imagético-textual numerado $(1,2,3, \ldots)$, o leitor é remetido à nota de fim de página a ele correspondente $(\mathrm{N} 1, \mathrm{~N} 2, \mathrm{~N} 3, \ldots)$ e, inversamente, ao clicar sobre qualquer região textual de uma nota de fim de página, o leitor é remetido de volta ao segmento imagético-textual que lhe é correspondente. Não se trata, portanto, de uma escrita argumentativa. Dela, melhor seria dizer tratar-se de uma escrita terapêutico-performativa - num sentido próximo, porém não idêntico, àquela praticada por Wittgenstein em seus escritos filosóficos - que forneceria aos leitores um tipo de esclarecimento baseado nos modos como tais obras cinematográficas diversamente nos afetaram e nos mobilizaram a significar - isto é, a ver de outras maneiras, mediante a disciplinada exploração investigativa posterior das remissões, das analogias sensiveis e dos envios imaginários dispersivos que o ato de assistir a um filme incontrolavelmente produz nos esxpectadores, que sempre se comportam numa 'sala de cinema' como esxpectadores com $s$ e com $x$ - os modos doentios de nos envolvermos e de lidarmos com problemas vitais semelhantes no mundo contemporâneo. Assim, a nossa escrita terapêutico-performativa segmentada e numerada, embora proponba aos leitores uma ordem de percurso, não os obriga a seguirem rigidamente tal ordem. Ao contrário, ela os convida também a percorrerem casualmente tais segmentos, produzindo as suas próprias leituras autoterapêuticas.

1 - O pulo de Petúnia nas águas do rio Otinja.

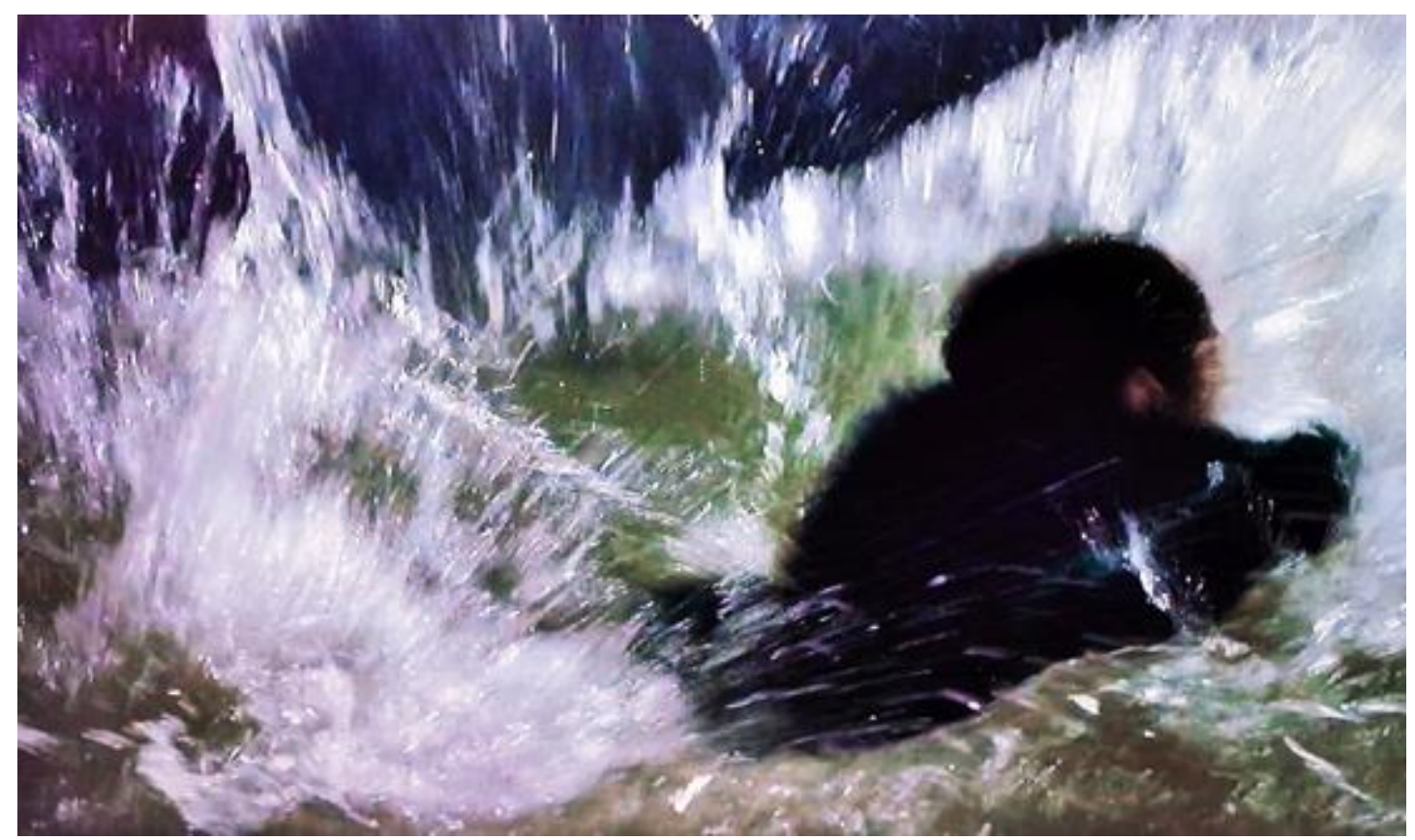


2 - Uma mudança imprevisível de humor da deusa Penitência mudou o destino de Petúnia. Deuses que controlam os modos como a aleatoriedade dos humores dos seres nãohumanos afetam os seres humanos são sempre mulheres.

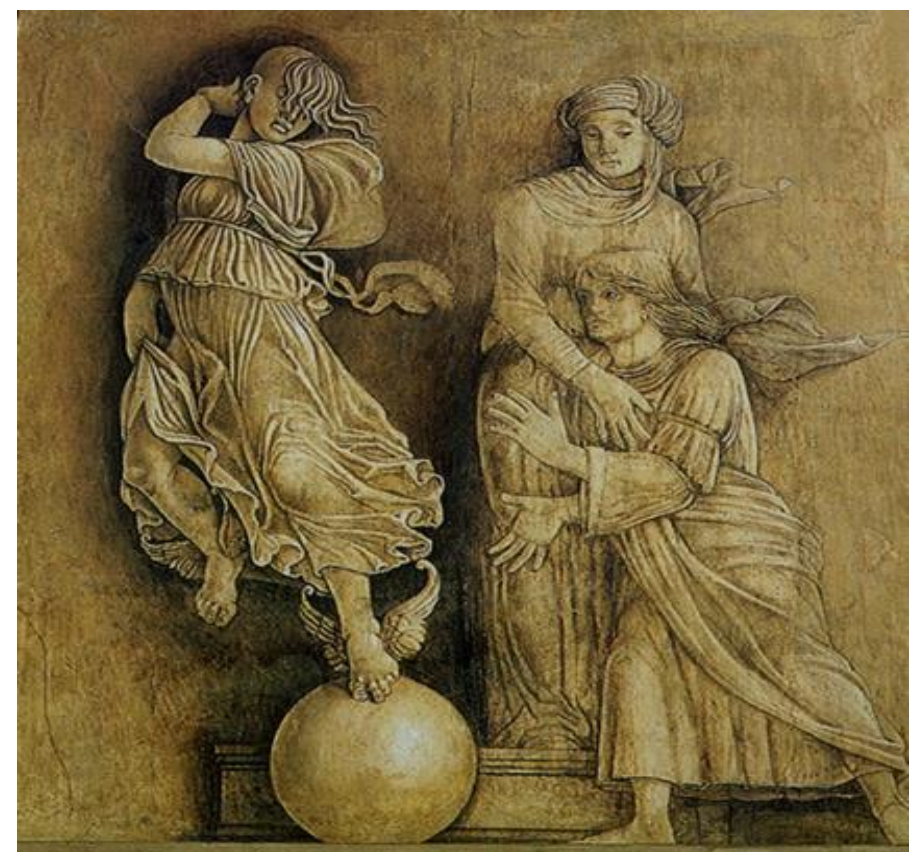

3 - Tique de Antioquia, a deusa grega do acaso, nos rastros de Ops, a deusa grega da abundância e da fertilidade.
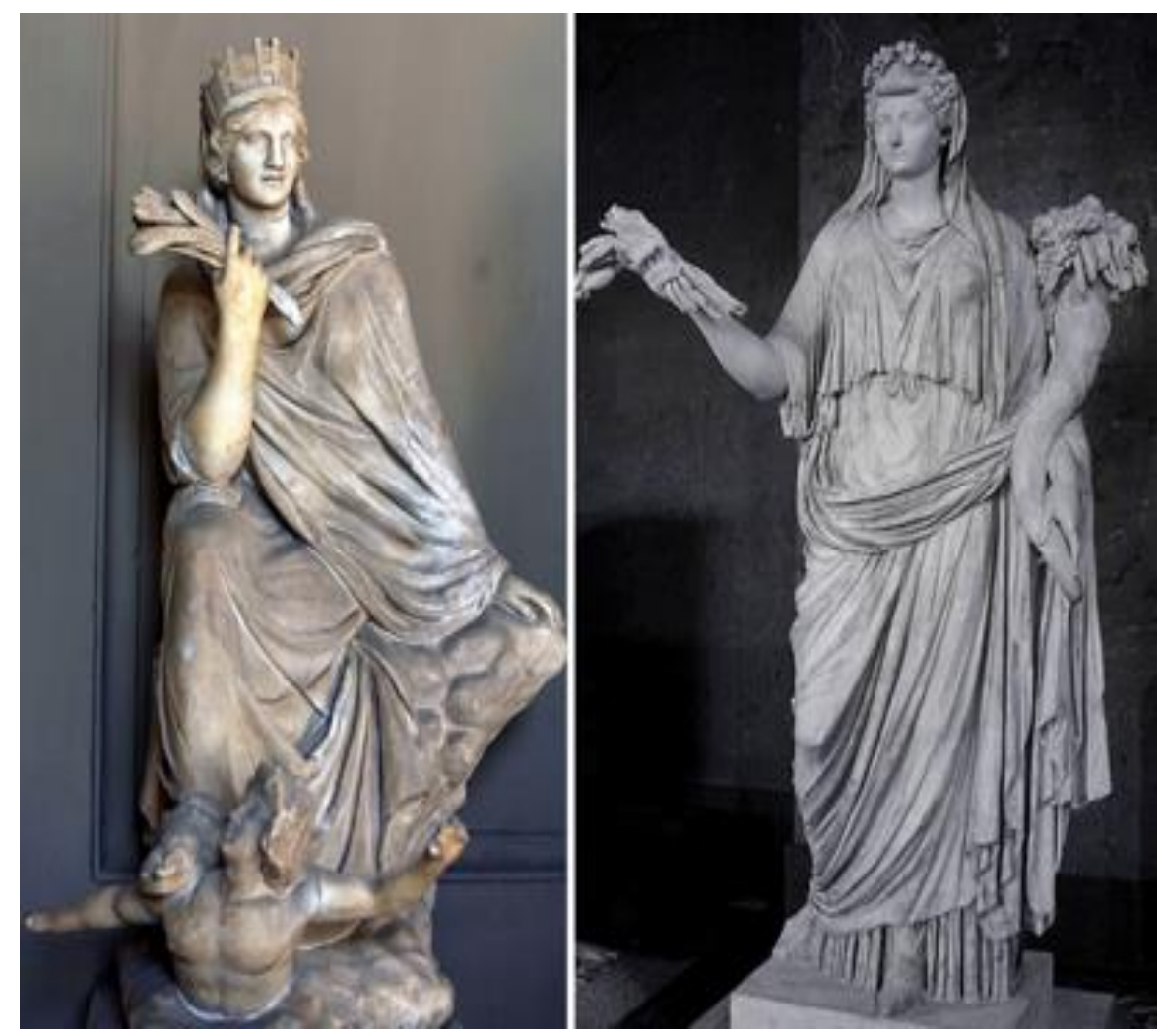
4 - "Então, o peão [garimpeiro] começou a se encontrar de noite com essa dona. Toda noite ia para o rio e ela estava lá. Uma mulher muito bonita, de cabelos louros, compridos, olhos bem azuis. Aí, pegava na mão dele e contava para ele de onde tirar ouro; dava muito ouro para ele, muito mesmo. Só que ele não podia falar nada para ninguém. Pois se dissesse qualquer coisa para o amigo, ela sumia, ia embora".

5 - Cacique foi a palavra inventada pelos colonizadores europeus para se referirem aos líderes das comunidades indígenas ameríndias. Já essas comunidades tinham nomes próprios distintos, em suas línguas nativas, para denominarem os seus líderes políticos. Ajuricaba era um tuxana para os manaós. Petúnias poderiam também ser ajuricabas e ajuricabas, petúnias:

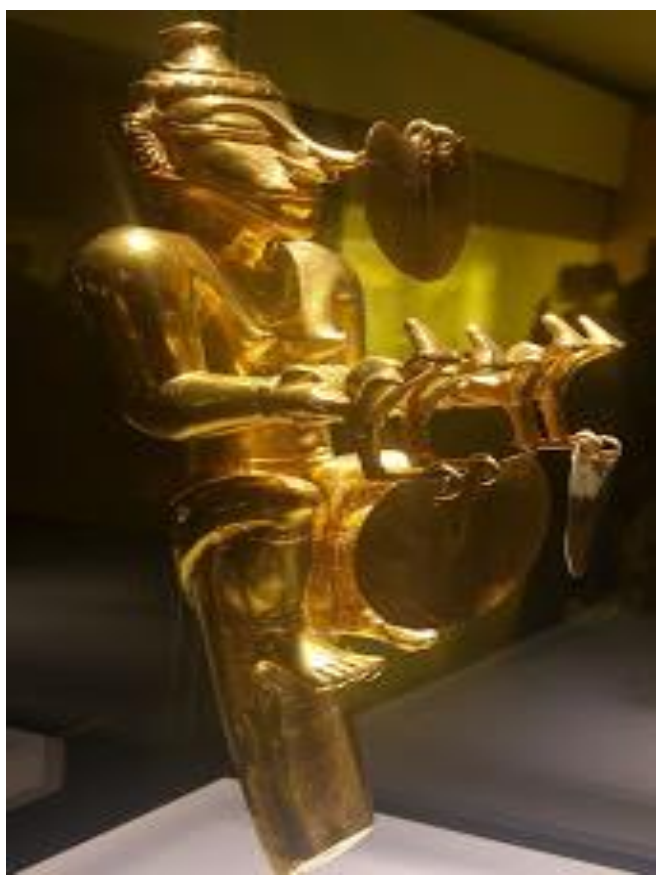

6 - A bandeira (1706 -1750) do reino de Portugal e Algarves, sob o reinado de D. João V, com o colar da Ordem de Cristo.
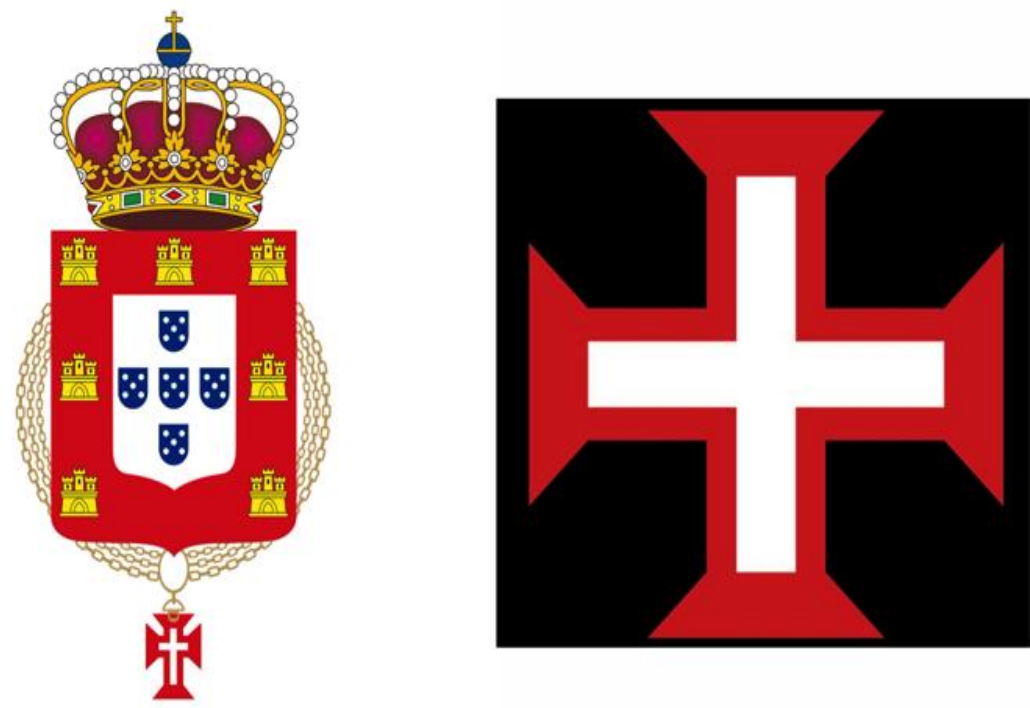
7 - O vermelho-brasa abrasador do pau-brasil, o mesmo tom de vermelho presente na bandeira do reino de Portugal e Algarves e da cruz pingente do colar da Ordem de Cristo.

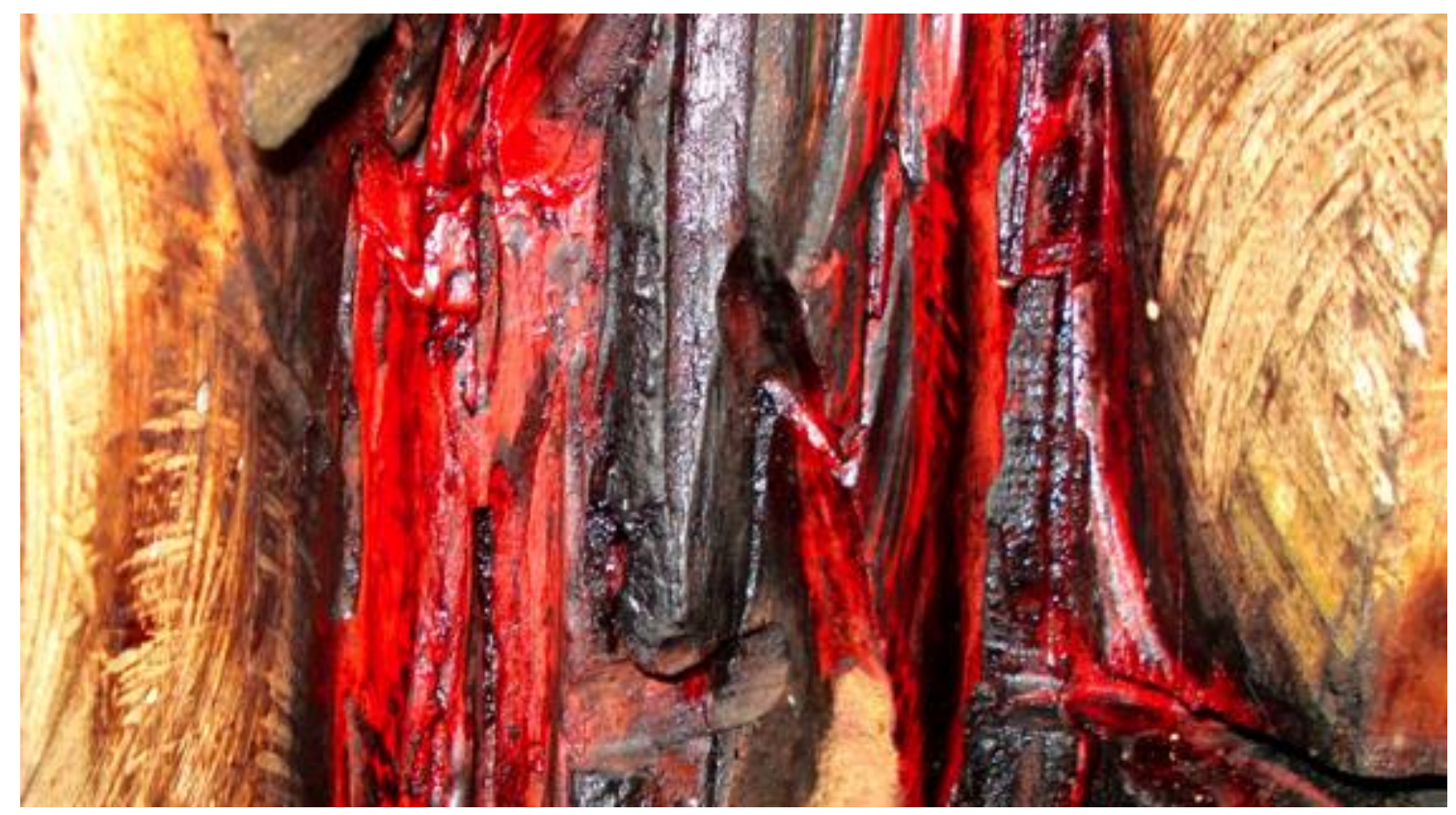

8 - Bandeira que era hasteada nas caravelas de Cristóvão Colombo, o almirante da Coroa dinástico-católica de Castela e Aragão.

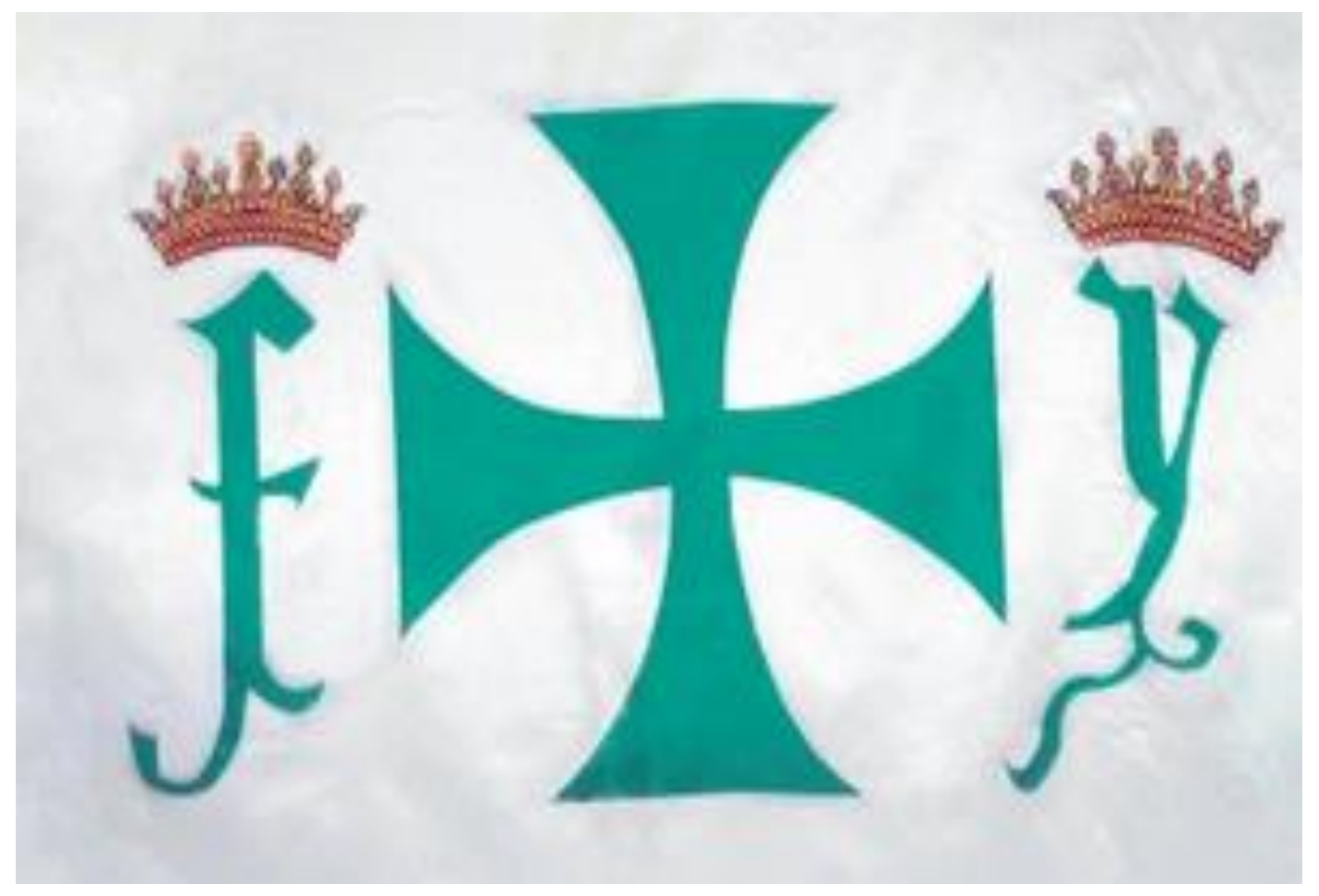


9 - Ele [o padre católico José Nicolino de Sousa] teria morrido porque "ao penetrar na caverna onde jazem, em montão, o ouro, a prata e as pedras preciosas, recebera e aspirara as emanações envenenadas dos metais e (...), poucos momentos depois, tendo disfarçado dos companheiros a pesquisa e a descoberta, voltara para a companhia dos mesmos, falecendo sem nada revelar".

10 - "Durante muito tempo as cruzadas foram consideradas como guerras religiosas provocadas por motivos piedosos e cristãos, para a reconquista dos lugares santos, conquistados pelos turcos. Essa ideia simplista começou a ser combatida no século XVIII, ocasião em que Voltaire, com a sua admirável irreverência, afirmou que as cruzadas não passaram de um tolo empreendimento, dirigido por criminosos irresponsáveis. Hoje, é evidente que não podemos continuar sustentando que as cruzadas tiveram uma causa única, seja ela espírito religioso, interesses econômicos ou ambições políticas; os motivos econômicos e políticos existiram sem dúvida, e até desempenharam um importantíssimo papel nesse movimento, mas também é certo que foram os motivos religiosos que deram às cruzadas a sua característica principal de guerra santa".

11 - A Cruz Rubra da Ordem militar de Cristo nas velas das caravelas portuguesas.

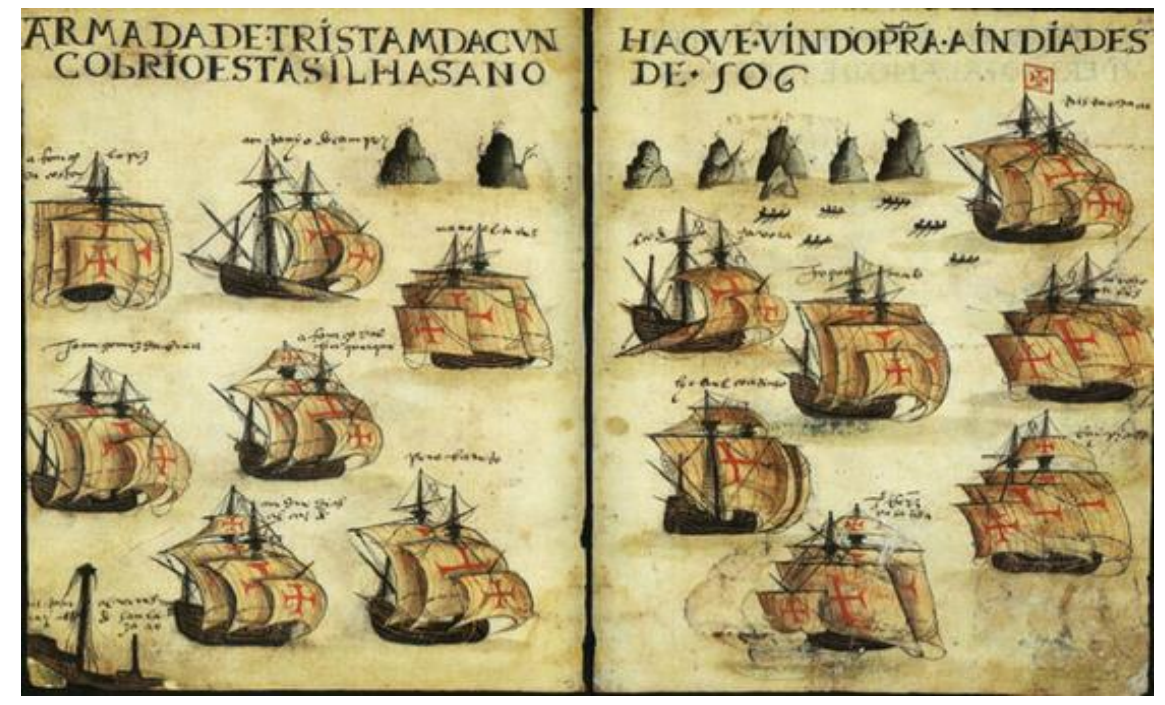

N12 - Cruzes da Igreja Ortodoxa Copta.
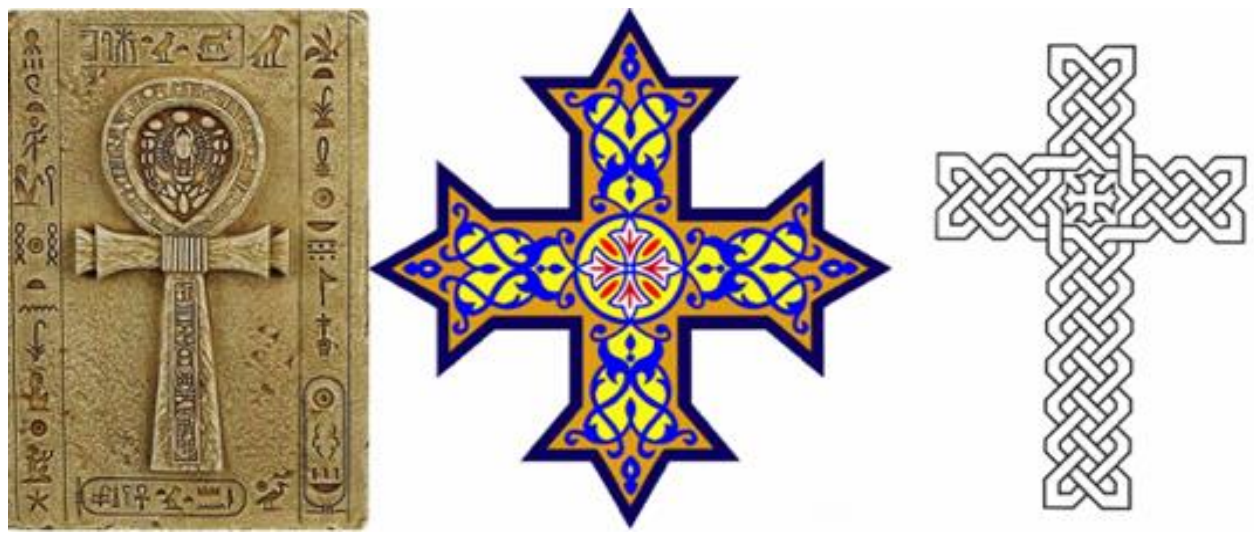
13 - O Batismo de Cristo, no rio Jordão, segundo Perugino e Pinturicchio.

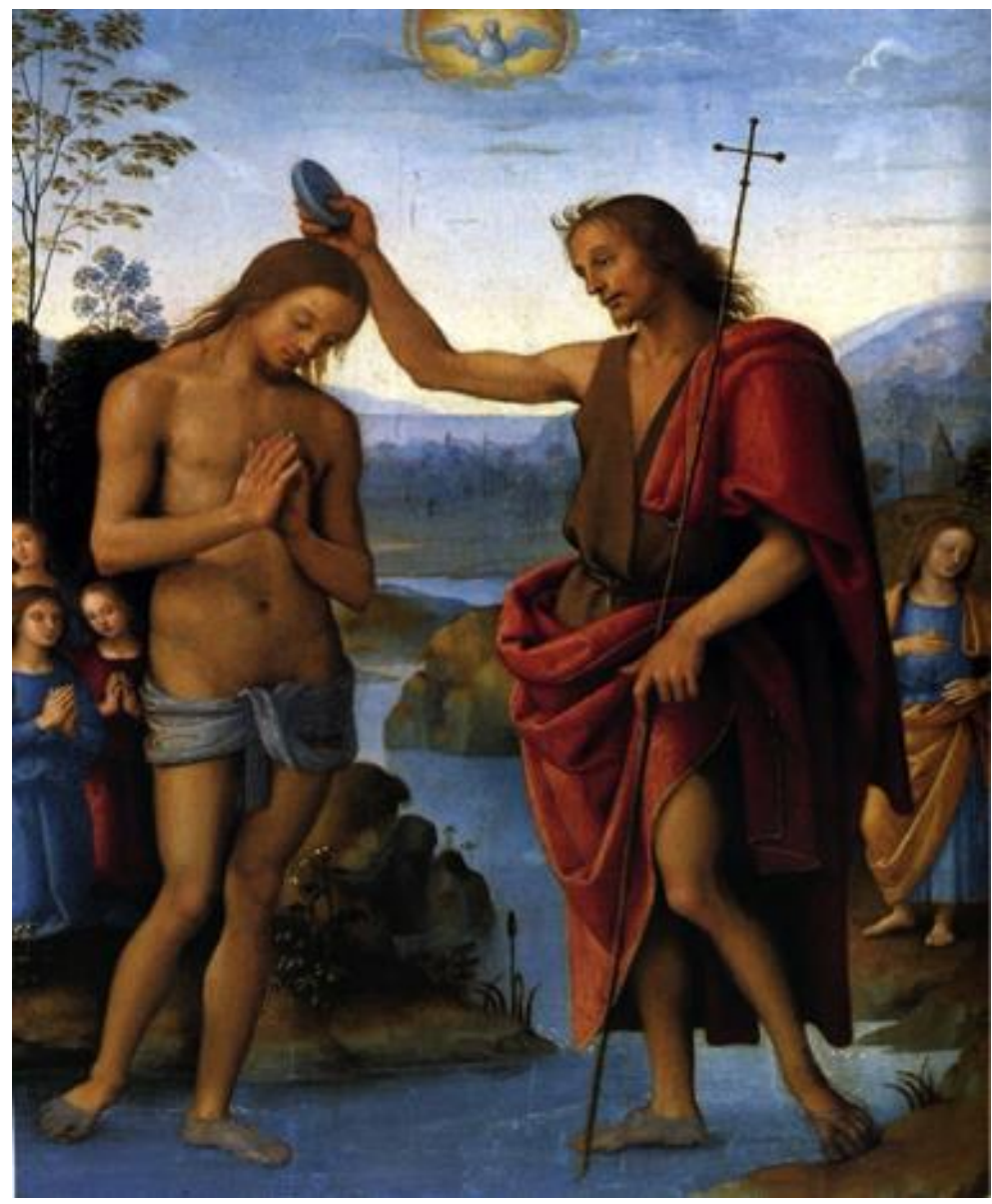

14 - A cruz de ramos de cereais e flores do pároco Kosta.

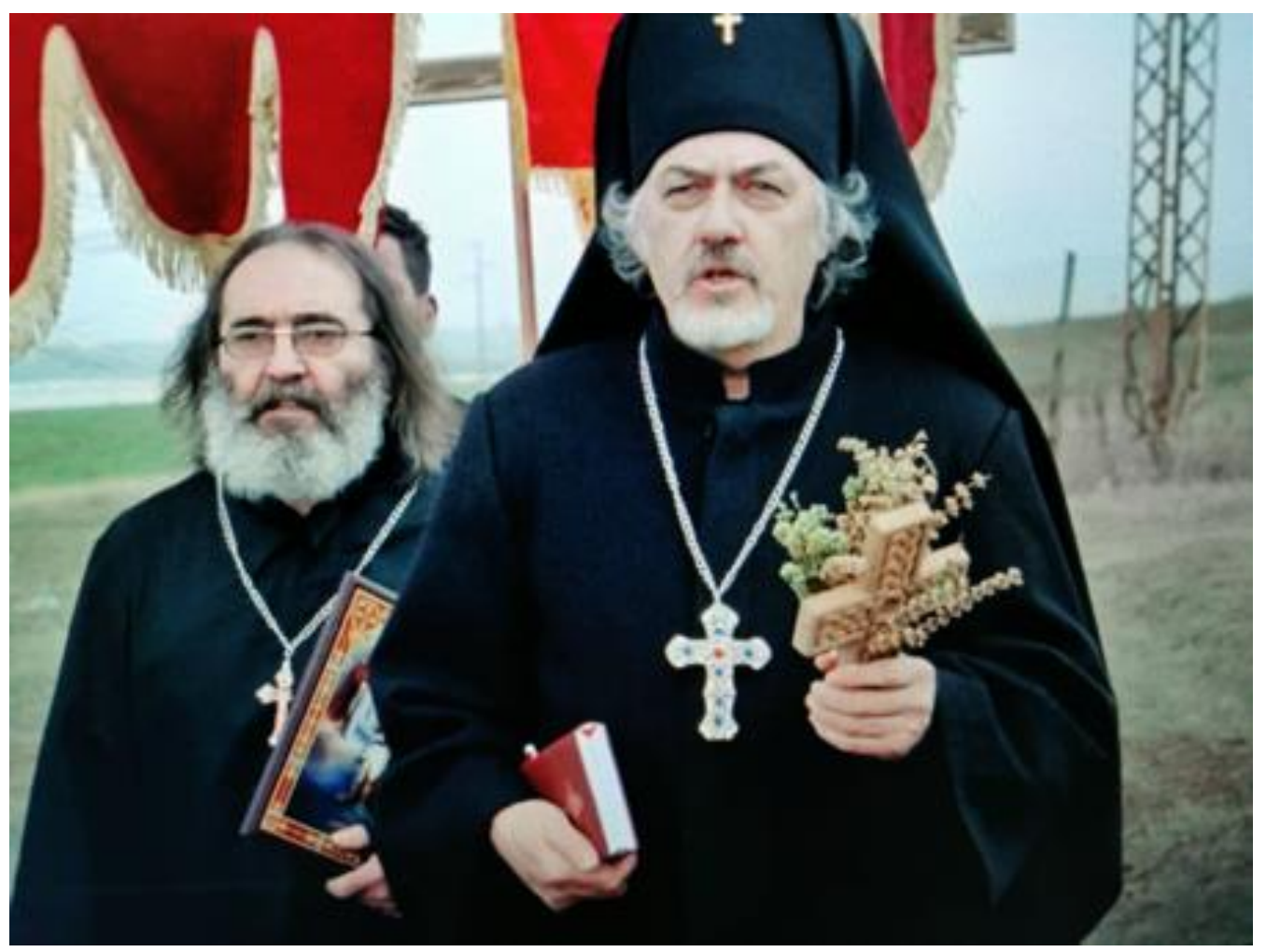




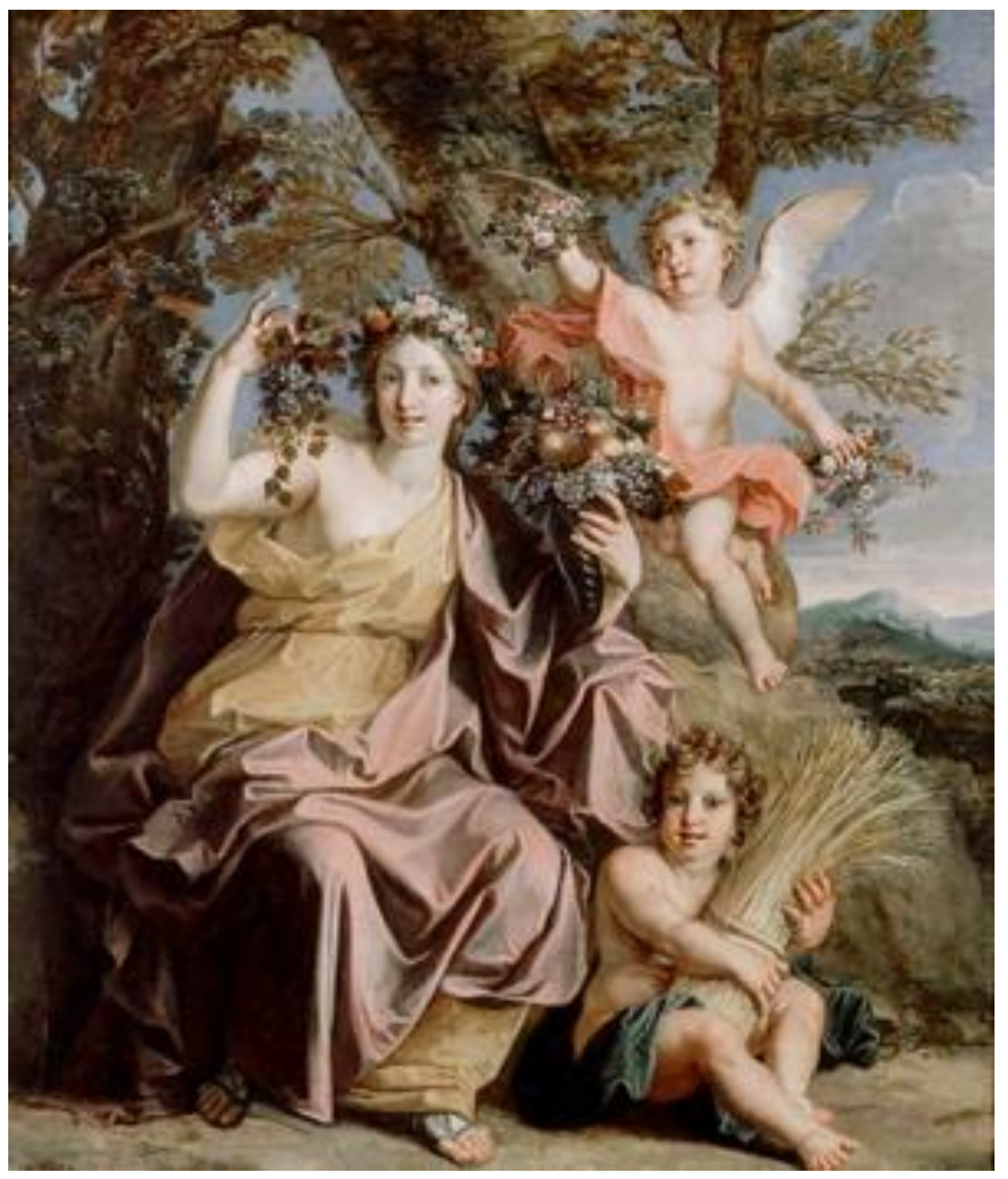

15 - "Já estavam regressando à Espanha as caravelas carregadas de ouro. Um novo deus havia nascido: "O ouro é excelente", dizia Colombo à Rainha Isabel, na linguagem franca da burguesia genovesa. "Com ele se conseguem tesouros, e quem possui tesouros pode fazer o que quiser neste mundo, até levar as almas ao paraíso".

16 - "Não destruam o lugar onde moram os meus genros [os Yanomami] e meus espíritos xamânicos! "É assim que a "natureza" fala aos brancos, mas eles não entendem. São surdos e ignorantes. Seu pensamento é perturbado por vertigens. Olham para suas peles/cascas de imagem (tupë siki) e aí veem outras coisas: o desenho da escrita das coisas que estão debaixo da terra e que eles desejam: o metal e o ouro".

17 - "Wiyu, a sucuri que também é a dona da água, possui o ouro. É uma entidade andrógena que tem o poder de se transformar em ser humano de qualquer sexo e enganar os humanos reais, seduzindo-os. Os Ye'kuana dizem que Wanaadi [o Demiurgo] enterrou o ouro para os Ye'kuana usarem, mas ele deve ser tirado com muito cuidado e parcimônia. Só se pode extrair um pouco de cada vez, quando é preciso comprar alguma coisa, porque 
a ganância enfurece Wiyu. É por isso que só os homens maduros devem conhecer o ouro, porque os jovens não têm autocontrole".

18 - "O ouro, ele exige muita coisa da gente. Você nāo pode pensar em ganância - canoa, casa boa, essas coisas quando vai atrás dele. Pois se ligar para elas, zanga, queima. Nāo! Tem que pensar naquele ouro e mais nada. Pois o ouro é como um fogo - corre, e depois, some feito fumaça. [...] Era para ele ter segurado aquele ouro e ficado rico, mas nāo soube fazer o necessário. Aí, pronto, sumiu tudinho".

19 - "En aquella laguna de Guatavita se hacía una gran balsa de juncos, y aderezábanla lo más vistoso que podían... A este tiempo estaba toda la laguna coronada de indios y encendida por toda la circunferencia, los indios e indias todos coronados de oro, plumas y chagualas... Desnudaban al heredero (...) y lo untaban con una liga pegajosa, y rociaban todo con oro en polvo, de manera que iba todo cubierto de ese metal. Metíanlo en la balsa, en la cual iba parado, y a los pies le ponían un gran montón de oro y esmeraldas para que ofreciese a su dios. Entraban con él en la barca cuatro caciques, los más principales, aderezados de plumería, coronas, brazaletes, chagualas y orejeras de oro, y también desnudos... Hacía el indio dorado su ofrecimiento echando todo el oro y esmeraldas que llevaba a los pies en medio de la laguna, seguíanse luego los demás caciques que le acompañaban. Concluida la ceremonia batían las banderas...Y partiendo la balsa a la tierra comenzaban la grita... Con corros de bailes y danzas a su modo. Con la cual ceremonia quedaba reconocido el nuevo electo por señor y príncipe".

20 - "O ouro e os outros minérios que não conheço Omamë encontrou e depois escondeu embaixo da terra para que ninguém mexesse com eles. São coisas que não se comem. Só deixou de fora aquilo que comemos [...]. Estes minérios ninguém os come, são coisas perigosas. Só provocam doenças que se alastram e matam todo mundo, não somente os Yanomami, mas os brancos também".

21 - "Enquanto for conservado no frio das profundezas da terra o ouro é inofensivo. Mas, não contentes em extraí-lo, os garimpeiros ainda o queimam e o expõem ao sol em latas de metal. Este aquecimento "mata" o ouro e o faz "exalar" uma fumaça pestilenta que se propaga em todas as direções. Esse calor patogênico afeta não só os seres humanos, mas também a floresta, que vê seu "sopro" esvair-se e seu "princípio de fertilidade" fugir, tornando-se inabitável para seus donos, os espíritos xamânicos (que "possuem" a floresta)".

22 - "En julio de 1539, ante el licenciado Santa Cruz en Cartagena, declaraba Belacázar haber salido de Popayán, con doscientos hombres por San Juan del año 1538 'Y que pasó por las sierras Nevadas hacia el Este y caminó ocho meses, y que siempre halló pueblos poblados de jornada en jornada y mantenimientos". Es significativa la declaración de haber iniciado su expedición dirigiéndola al Este y no al Norte, como se supone por haber llegado al Nuevo Reino. La declaración confirma, pues, su intención de buscar el "Dorado" que siempre se situaba al oriente de los Andes. ¿Por qué se preguntará, no se dirigió desde Quito directamente al oriente sino primeramente a Popayán, es decir al Norte? Aunque ningún documento histórico ofrece una explicación, no es difícil descubrir la causa, quiso salirse como efectivamente se salió del territorio concedido a Francisco Pizarro: 270 leguas por la costa del Pacífico y lo que descubriere la tierra adentro, pues si desde Quito, yendo hacia el Oriente, hubiera descubierto el Dorado, este hubiera pertenecido por derecho a la 
gobernación de Francisco Pizarro. Se dirigió al Norte a Popayán, y desde allí, como creía estar ya fuera de los límites de quella gobernación, trató de llegar al dorado atravesando la cordillera Oriental. Sigue declarando Belalcázar que después de ocho meses estaba en el nacimiento del Río Grande Magdalena - es decir en el Macizo Central Andino. Indudablemente ignoraba de encontrarse a pocos días de jornada de Popayán, si hubiera tomado un camino directo. No hay duda que durante aquellos ocho meses Belalcázar había intentado atravesar la Cordillera Oriental para buscar su dorado. Las inexactas y sin dudas contradictorias informaciones sobre ese fantástico paraíso, lo hicieron deambular por valles y serranías de la Cordillera.Tal declaración prueba que la expedición de Belacázar no se inició hacia el Norte en busca de la meseta chibcha, sino al Este o Sureste en busca del dorado, debido a las noticias de "Cundirumarca" que había recibido del indio de Latacunga $[\ldots]$.

23 - "Relacionado originalmente a um chefe indígena coberto de ouro em pó literalmente "El Dorado" (O Dourado) -, o mito logo evolui para uma terra dona de riquezas além de toda a expectativa destinada a atrair levas sucessivas de rapazes aventureiros. Desde o final do século XVI, busca-se uma metrópole fabulosa situada na beira de um misterioso lago de águas salgadas, cidade que ganha lugar nos mapas sob o nome de Manoa ou - conforme preferem alguns - Manoa do Eldorado. Perdido em algum lugar das vastas florestas sul americanas, eldorado sofreria uma mudança decisiva graças à exploração do Orinoco levada a cabo em 1590 por Antonio de Berrio. Responsável pelo relato da expedição, Domingo Vera teria dado ouvido a supostas revelações de um certo Juán Martínez, que dizia ter visitado o Eldorado em suas perambulações. Segundo essa nova versão da fábula, cabia aos servos untar os nobres da cidade com uma resina e nela soprar ouro em pó, com o auxílio de caniços, até que os corpos brilhassem da cabeça aos pés. Situada à beira de um lago chamado Parima, Manoa seria a capital de um reino muito rico em ouro, pois esse metal era usado não só na confecção de ídolos e adornos, mas também na de armaduras, escudos e outros objetos do cotidiano".

24 - Segundo a lenda de Eldorado, em espanhol El dorado ou O (homem) dourado - uma narrativa que se construiu e passou a circular no continente europeu, por volta da primeira metade do século XVI, sobretudo entre os colonizadores espanhóis e portugueses ávidos por ouro que participavam das expedições exploratórias das terras ameríndias de Abya Yala, hoje conhecidas como América do Sul -, havia uma cidade construída toda em ouro, pertencente à comunidade indígena muísca ou chibcha - habitantes originários das terras hoje denominadas Colômbia, em homenagem ao conquistador espanhol Cristóvão Colombo -, cujos artistas produziam seus artefatos em ouro e cujo líder costumava cobrir todo o seu corpo com ouro em pó antes de mergulhar em um lago dos Andes. Embora os colonizadores espanhóis tivessem chegado, de fato, a estabelecer contato com essa comunidade e a constatar que os muísca produziam mesmo artefatos em ouro - muitos dos quais constituem, na atualidade, o acervo do Museu do Ouro, em Bogotá, na Colômbia -, constataram também que a imaginada cidade muísca de ouro era, na realidade, uma cidade imaginária. Porém, eles não se contentaram em saquear o ouro dos muísca e continuaram persistindo na busca da cidade de ouro, de Eldorado. Supuseram, então, que ela se localizava nos Llanos da Venezuela e nada encontrando, projetaram-na em terras hoje constituintes do estado brasileiro de Roraima, e depois, nas Guianas. Nada encontrando 
também nessas terras, supuseram ainda que o Eldorado se localizaria no imenso e imaginário lago Parima, no Perú.

25 - A Eldorado de Poe.

Era uma vez um jovem cavaleiro valente

que sob sombra ou sol de ouro ardente

e por canções de sóis dourados embalado saiu em busca de Eldorado.

Após tantas selvas verde-esmeralda percorridas

o coração rubi-vibrante do cavaleiro ofegante

por uma vida embalado

pela febre amarela da sombra de Eldorado

de repente se viu enlutado

pela sombra ônix-gris de uma imensa terra de giz.

- "Aponta sombra-assombração

à minha alma assombrada a direção

daquela terra dourada

apenas por ouro habitada

jamais por alguém alcançada!".

- "Eldorado? Fica além das Montanhas Douradas de Altai.

Além do Vale da Sombra, digamos... Vamos!"

26 - A Eldorado de Heródoto.

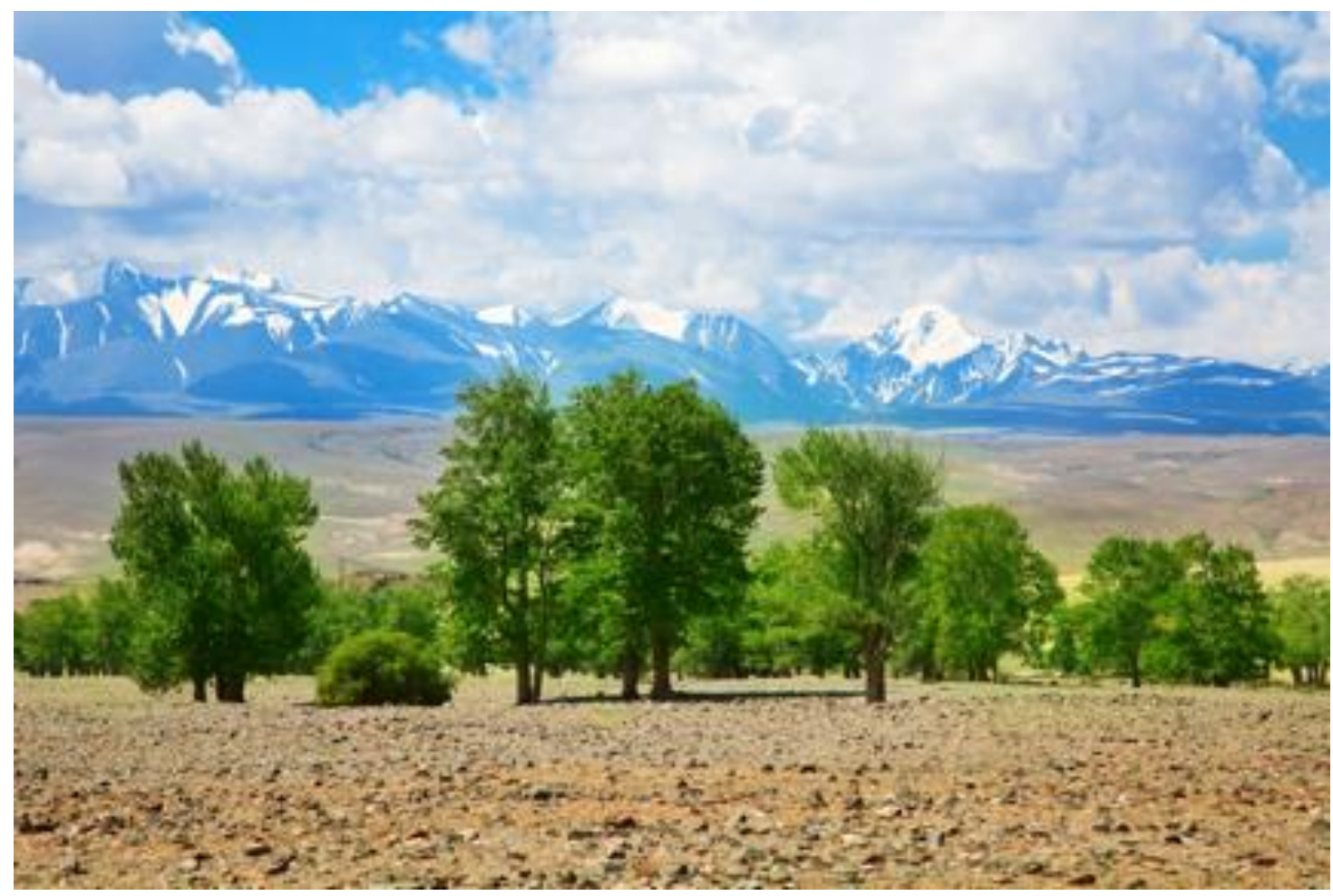


27 - A Manoa ou Eldorado de Theodore de Bry.

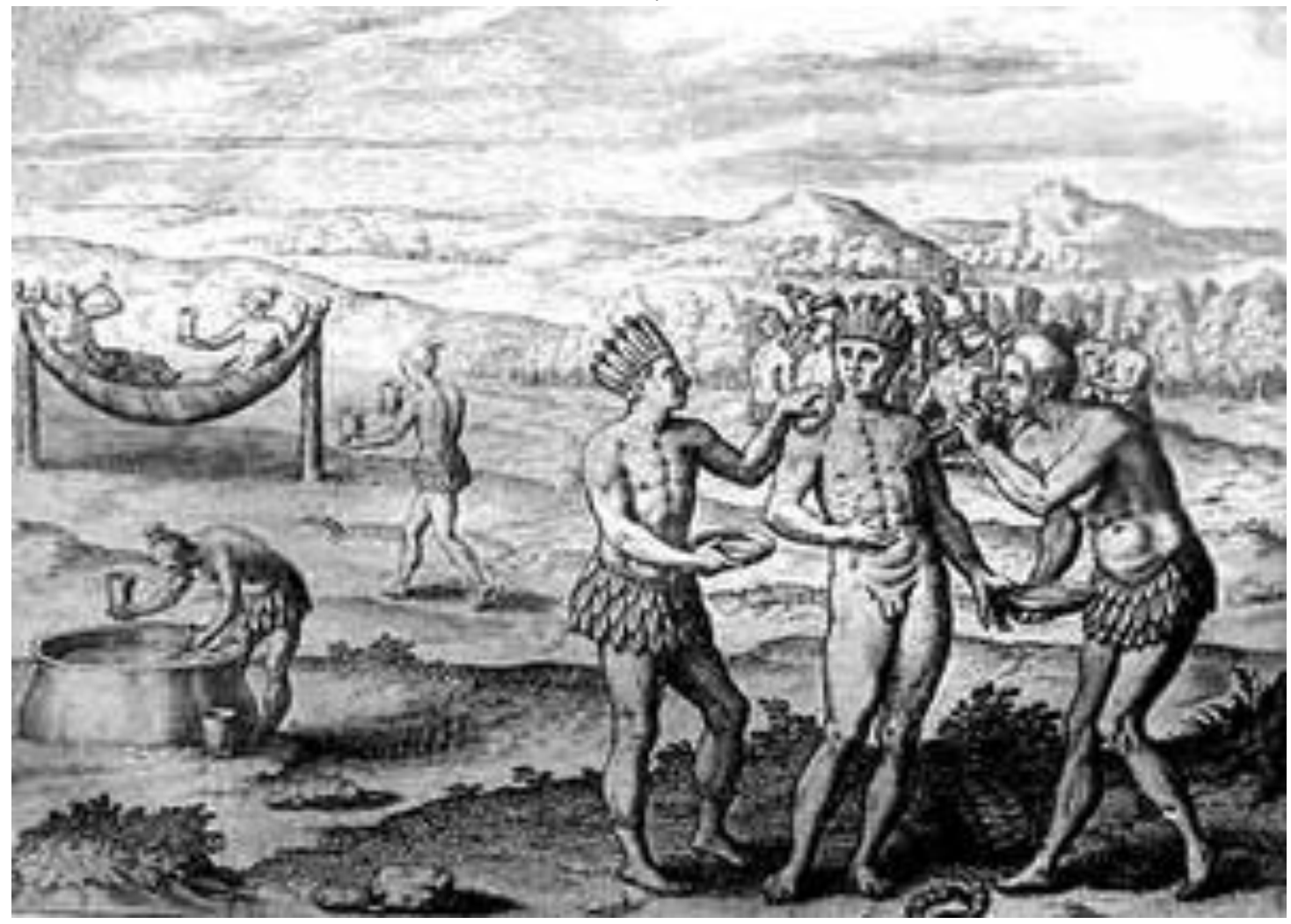

28 - A Manoa cartográfica de Hondius \& Janssonius.

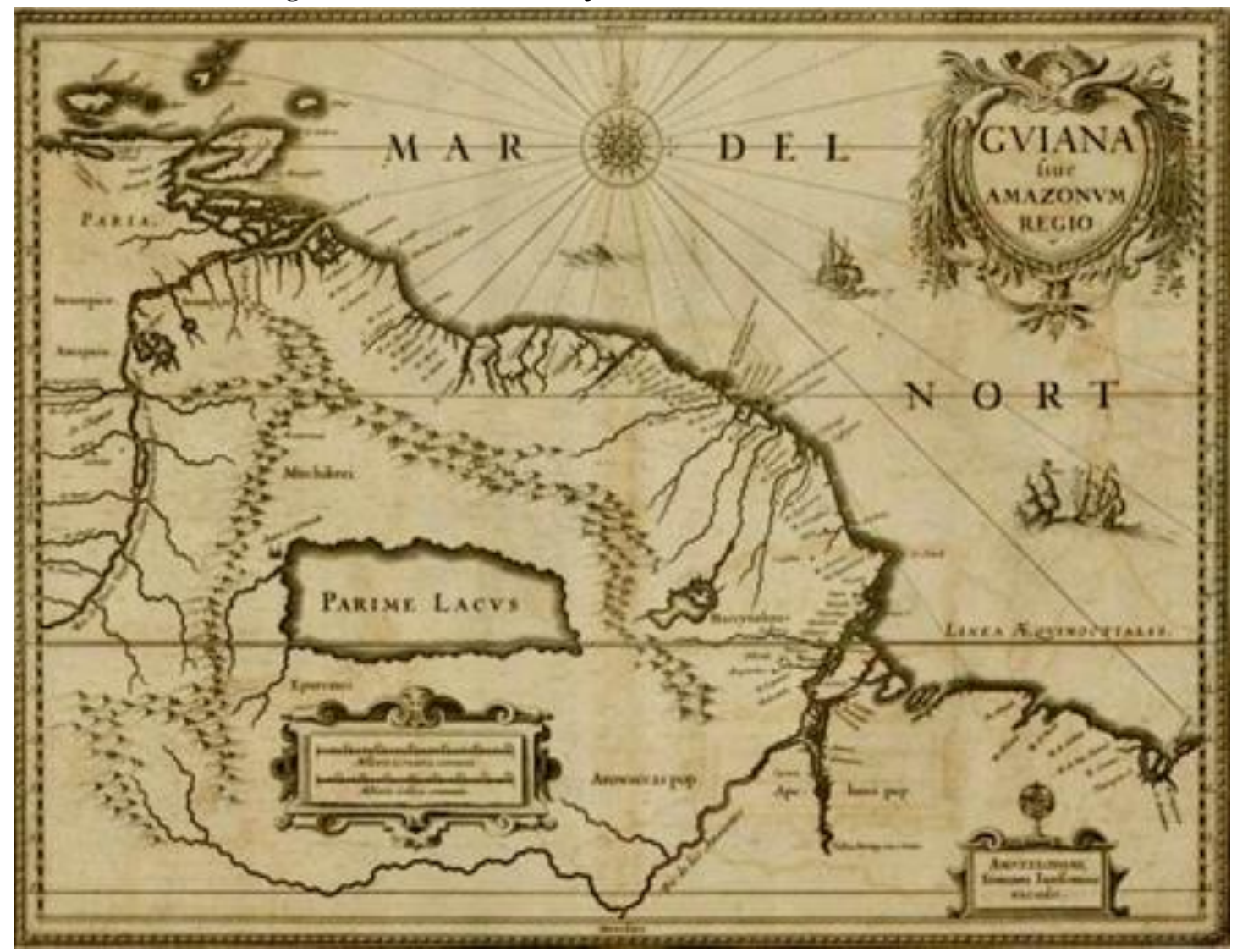

29 - Segundo fabulosos relatos coloniais acerca das terras de Abya Yala, comparada às outras cidades do Império espanhol, a lendária Manoa as deveria superar "por sua amplidão, 
riquezas e excelente localização". A lendária Manoa chegou mesmo a ser eleita a capital de um império que supostamente guardava mais ouro do que todo o Peru. E supostamente teria um número maior de vilas do que o Peru "no apogeu de seu esplendor".

30 - "Esta riqueza aumentará todos os dias se os outros príncipes negligenciarem as ocasiões que lhes são oferecidas e permitirem acrescentar aos seus patrimônios este império que, de longe, ultrapassa todos os outros".

31 - A lendária cidade de Manoa, às margens do Lago Dourado, nos modelos cartográficos europeus do século XVI.

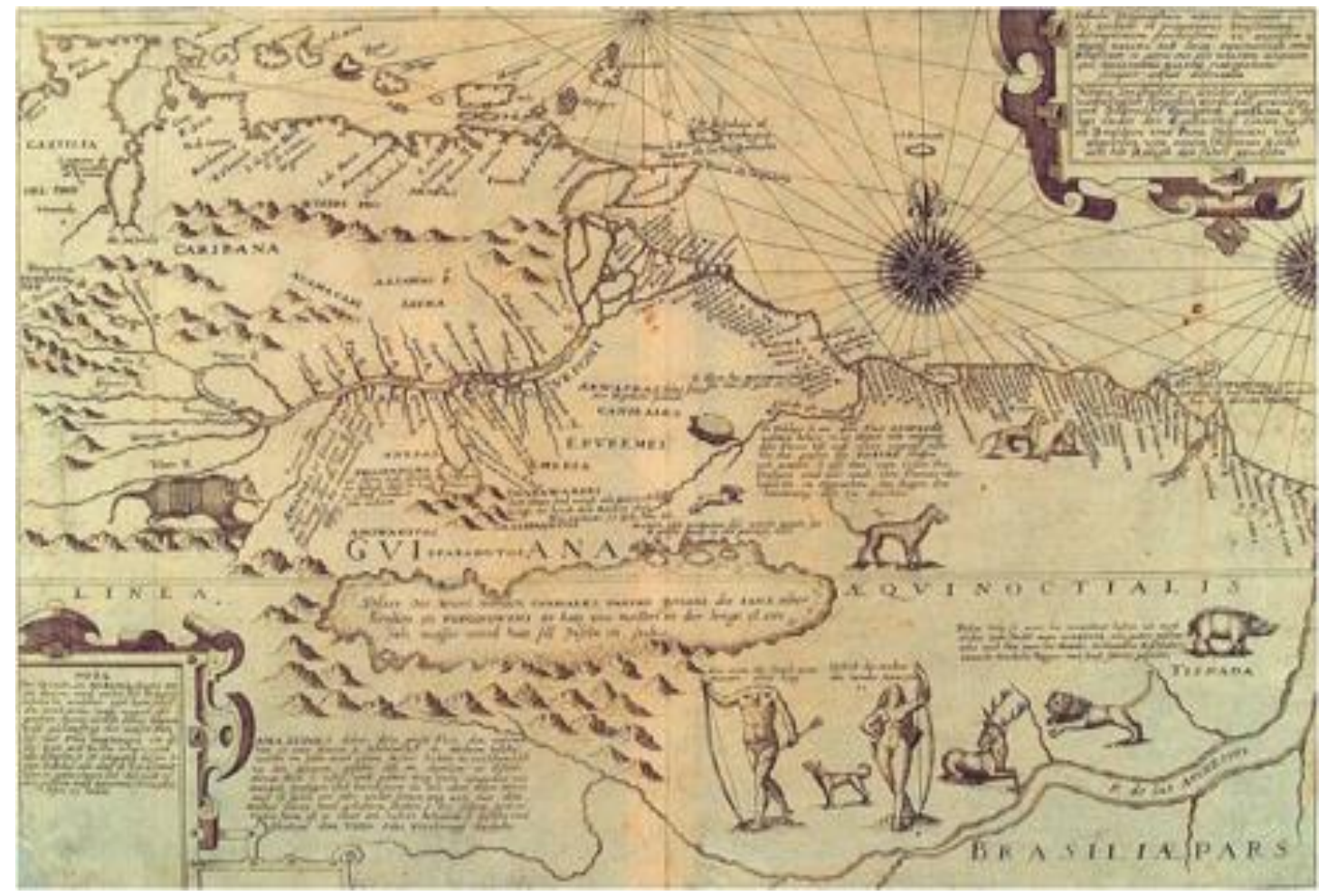

32 - "Meu avô era o guarda da vontade de Manari. Manari falava pela sua boca, dizendo aos manaós para expulsarem os invasores da floresta".

33 - "Parabenizo Belchior pelo trabalho de conquista dos índios de boa índole, sem eles perderíamos muitas vidas. Além de nos servirem de escravos, conhecem os segredos das ervas e das riquezas que nos interessam e podem descobrir caminhos na mata".

34 - "Desembarca Enéias em Cumas, e com um ramo de ouro como passaporte passa para o outro mundo. Desce a um misterioso reino subterrâneo; vê desenrolar-se ante si o passado e o futuro. Visita o mundo dos mortos e o mundo dos que ainda vão nascer. Cruza o rio do Esquecimento; atravessa os campos da Tristeza; vê o inferno e seus castigos. Deposita lá o ramo de ouro e dirige-se ao Elíseo, onde é recebido pelo espírito de seu pai, que lhe expõe a doutrina da imortalidade. Quando volta a subir à terra pela porta do sonho, é um iniciado, consagrado, elevado a uma esfera superior, o instrumento consciente e eleito pela Providência que governa os mundos". 
35 - Enéias e a Sibila de Cumas nos pincéis e tintas de Turner.

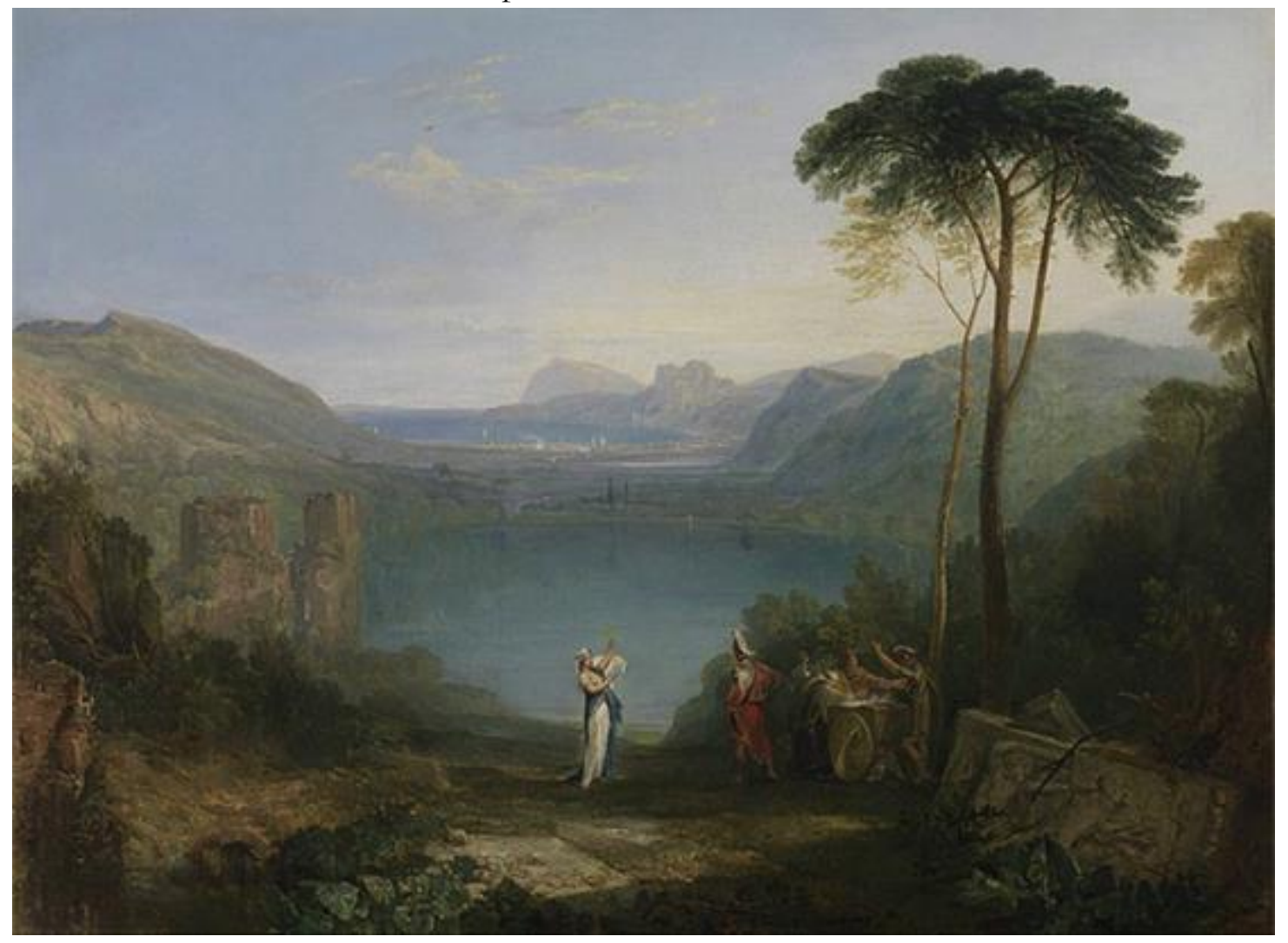

36 - "O lago ainda vítreo dorme

sob as árvores sombrias de Arícia.

Árvores sob cujas sombras

o terrível sacerdote reina.

O sacerdote que matou o matador

por outro matador será morto".

37 - "Isso porque o modo do ouro é assim. Se ele for para ser seu, ele será, mas se não for, não há nada que você pode fazer. O ouro decide, e somente ele sabe quando, e mesmo se ele irá aparecer".

38 - Já vi tantas vezes isso, em que um peāo trabalha um barranco e nāo acha nada, acha bem pouquinho, depois de todo aquele trabalho. [..] Aí, vem outro e encontra ouro, muito ouro, naquele mesmo lugar. Pois é, aquele rapaz, o Lulāo, trabalhou num lugar por muito tempo. Cavou, cavou, cavou, mas achou pouca coisa. Aí, por fim, deixou, foi embora. E logo depois, veio aquele cara do Paraná, começou a trabalhar no mesmo lugar. "Escuta, rapaz, ali você nāo acha nada", disseram para ele, para "o Lulāo, que passou tanto tempo sem achar coisíssima nenhuma". Mas o cara nem ligou. Cavou, cavou, cavou e, no terceiro dia, bamburrou que era toda uma beleza. Ele tirou bem setenta quilos de ouro, só na māo. 39 - "O ouro transforma os homens livres em servos, mas também abre as portas do inferno".

40 - Em 2011, quando o governo de Hugo Chávez baixou um decreto-lei estatizando a extração de ouro e atividades correlatas, anunciou-se uma série de planos para organizar e 
controlar a mineração no país. A ideia, mais uma vez, era obter uma nova fonte de receita, para além do petróleo. O mais famoso desses projetos foi o Arco Mineiro do Orinoco (AMO), que só deslanchou em 2016, no governo de Nicolás Maduro, num território de $111843,7 \mathrm{~km}^{2}$ (equivalente a $12 \%$ da área total da Venezuela). O AMO inclui Ciudad Guayana, além de zonas de preservação ambiental e terras indígenas, e é dividido em quatro setores onde há reservas de ouro, diamante, ferro, cobre, bauxita, terras raras, caulim, dolomita e coltan (columbita e tantalita). Com o projeto, Maduro ressuscitou o mito do Eldorado em pleno século XXI. Um Eldorado feito de tragédias, grandes e pequenas, como pude constatar em El Callao, Tumeremo e El Dorado - as cidades da região que visitei.

41 - "Na cultura ocidental, exerce-se propriedade sobre as terras para explorá-las economicamente, o ordenamento territorial que propõe o Estado tem uma visão limitada ao contemplar somente o aspecto material do elemento geográfico".

42 - A nova febre do ouro na Amazônia colombiana coloca comunidades indígenas tradicionais na luta contra uma mineradora pelo seu território ancestral.

43 - "Todos os indígenas que se envolveram com ouro estão hoje extintos. O ouro é o reflexo da luz na terra; é tão sagradi que é melhor deixá-lo quieto. [...] Do modo como as coisas estão agora, já começamos a morrer. [...] Seja parque, seja resguardo, seja o que seja, este território é nosso". Para os xamãs ou conhecedores, o ouro também tem como função permitir a visualização dos problemas e enfermidades existentes no mundo, bem como as que podem atingir o seu território. Se as restrições dadas para o manejo do ouro não são seguidas, chegam as enfermidades, e os xamãs ficam impossibilitados de combatê-las a partir de seus conhecimentos tradicionais. Assim, esta situação acaba por tornar-se uma ameaça para a sobrevivência dos povos do Apaporis".

44 - "Retirar o ouro da Terra é como apagar o sol".

45 - A empresa canadense Belo Sun Mineração objetiva explorar cerca de 3,8 milhões de onças em reservas provadas e prováveis de ouro na região amazônica de Volta Grande do Xingu, estado do Pará. Isso representa o maior depósito ainda não explorado do metal no Brasil, segundo o site da companhia. Ela é uma subsidiária brasileira da Belo Sun Mining Corporation pertencente ao grupo Forbes \& Manhattan Inc., um banco mercantil de capital privado que desenvolve projetos de mineração em todo o mundo.

46 - "Quais são os objetivos e justificativas para a realização do Projeto Volta Grande? A Belo Sun tem como objetivo explorar os recursos minerais resultantes da pesquisa geológica realizada, utilizando tecnologia de ponta e investimento em logística, trazendo benefícios para a população local sob a forma de geração de empregos e renda, geração de impostos para o município, dentre outros. O empreendimento irá gerar empregos diretos e indiretos na região, tanto na fase de implantação quanto na fase de operação, bem como irá gerar impostos que serão recolhidos no município, no estado e também na esfera federal [...]. Além disso, é previsto também uma melhoria significativa na qualidade de vida, em âmbito local, com a geração de empregos, impostos e melhorias de vias e acessos, dentre outras". 47 - "A mesma lógica etnocêntrica de colonização autoritária da Amazônia destinada a fomentar a criação de empresas rurais e incentivar a abertura de novas frentes de expansão da fronteira agrícola se repete na atualidade, sob novas roupagens, na forma de 
planejamento de megaempreendimentos econômicos coetâneos para fornecer interesses do agronegócio e da mineração, com vistas à exportação de commodities".

48 - "O Canadá tá crescendo, a Inglaterra tá crescendo, o Japão tá crescendo, tudo levando nossas riquezas naturais, e na hora da gente desfrutar, quem tá disfrutando é os estrangeiros, os imigrantes estão chegando no nosso país mandando, o qual, hoje aqui, o índio tá perdendo direito, o trabalhador tá perdendo direito, o garimpeiro".

49 - Réplica de uma jangada muisca na qual se realizava a Cerimônia do Eldorado.

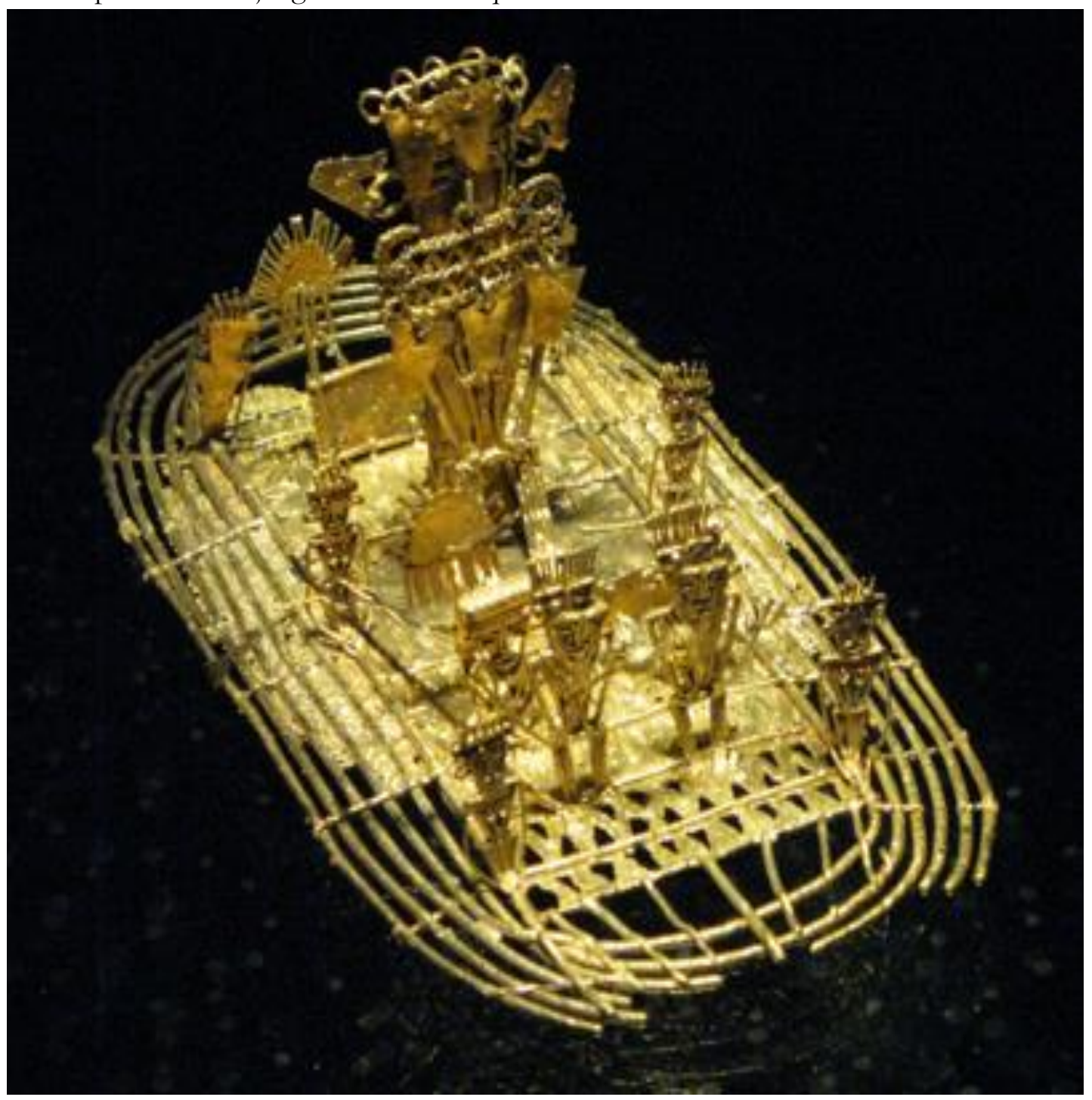

50 - "Não vos enganeis: as más conversações corrompem os bons costumes".

51 - "Até agora, segundo os relatórios, os selvagens se transformam em animais e conversam com feiticeiros com quem se encontram nos mais secretos esconderijos da floresta".

52 - "Tinha por essas bandas, um rapaz que matou uma cobra. Olha, eu mesmo não gosto muito de cobra, acho um bicho nojento, muito traiçoeiro. Mas não era para ele ter matado ela, pois traz muito azar. Acontece que os companheiros quase mataram ele. Pois ele teve que fugir daquele lugar. E olha, não acredito muito nessas coisas, mas dizem que nunca 
mais encontraram ouro naquele garimpo. Não sei explicar, mas acontece, é uma verdade. O ouro tem muito mistério".

\section{3 - Dafne e Apolo}

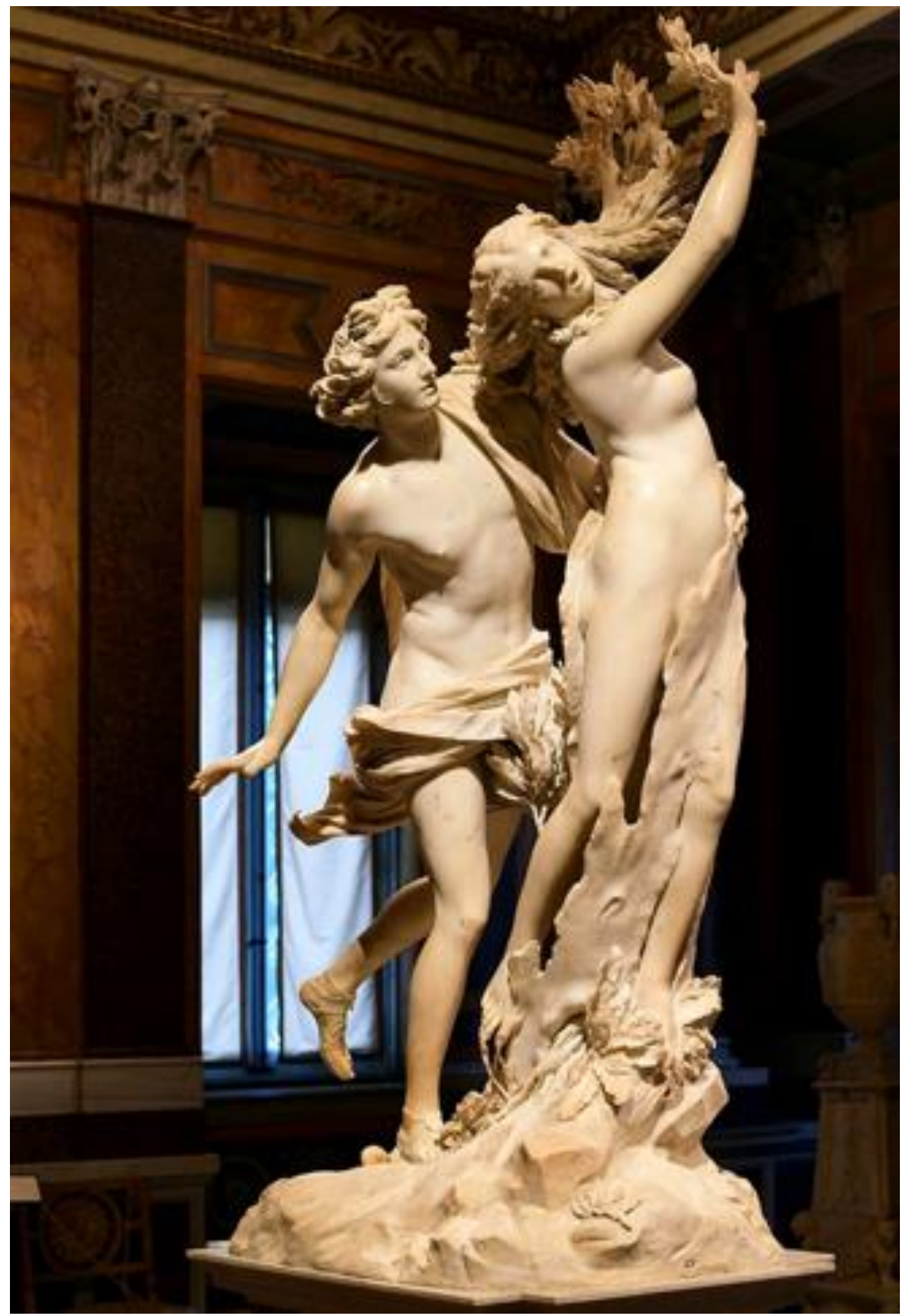

"E aquela flecha grossa, a que leva embora todo o amor, Cupido usou em Dafne, mas apontou a outra, a afiada, de ponta dourada, para Apolo, E no mesmo instante Dafne fugiu do apaixonado, Refugiando-se nos lugares mais secretos da floresta. Assim corriam o deus e a garota, um veloz, esperançoso, 
A outra aterrorizada, mas ele é mais rápido,

Levado pelas asas do amor, não dá descanso a ela,

Sua sombra encobrindo seus ombros, respirando nos seus cabelos revoltos.

As forças dela desaparecem, esgotadas pelo longo esforço do longo vôo;

Mortalmente pálida, olha para o rio de seu pai Peneo e grita:

"Ajuda-me! Se existe algum poder nos rios,

que ele transmute e destrua o corpo que despertou tanta adoração!"

E mal ela havia terminado a frase,

Seus braços ficaram entorpecidos e pesados;

Seus seios macios fecharam-se num delicado tronco,

seus cabelos viraram folhas,

Seus braços, ramos, e seus pés velozes criaram raízes,

E sua cabeça transformou-se na copa de uma árvore.

Tudo se transfigurou, exceto sua graça, seu brilho.

Mas Apolo a amou mesmo assim".

54 - “Todo manaó é um guerreiro. Todo manaó é dono do rio. Todo manaó é senhor de sua terra. É senhor de sua terra e de sua floresta. Eu sou Ajuricaba, chefe guerreiro, e o mais valente entre os manaós. [...] Onde se esconderam os irmãos de Ajuricaba? Agora, nem toda floresta, nem toda a escuridão da noite será suficiente para ocultar a vergonha de sua traição e de seu medo. Nem toda a água do rio será suficiente para escoar o pranto dos pais cujos filhos deram as costas à verdadeira coragem. Só a vingança descansará a alma dos que lutaram até o fim. Só a vingança aplacará a dor de tantos filhos mortos".

55 - O destino de Ajuricaba acorrentado à deriva na correnteza das águas imprevisiveis do Rio Negro.

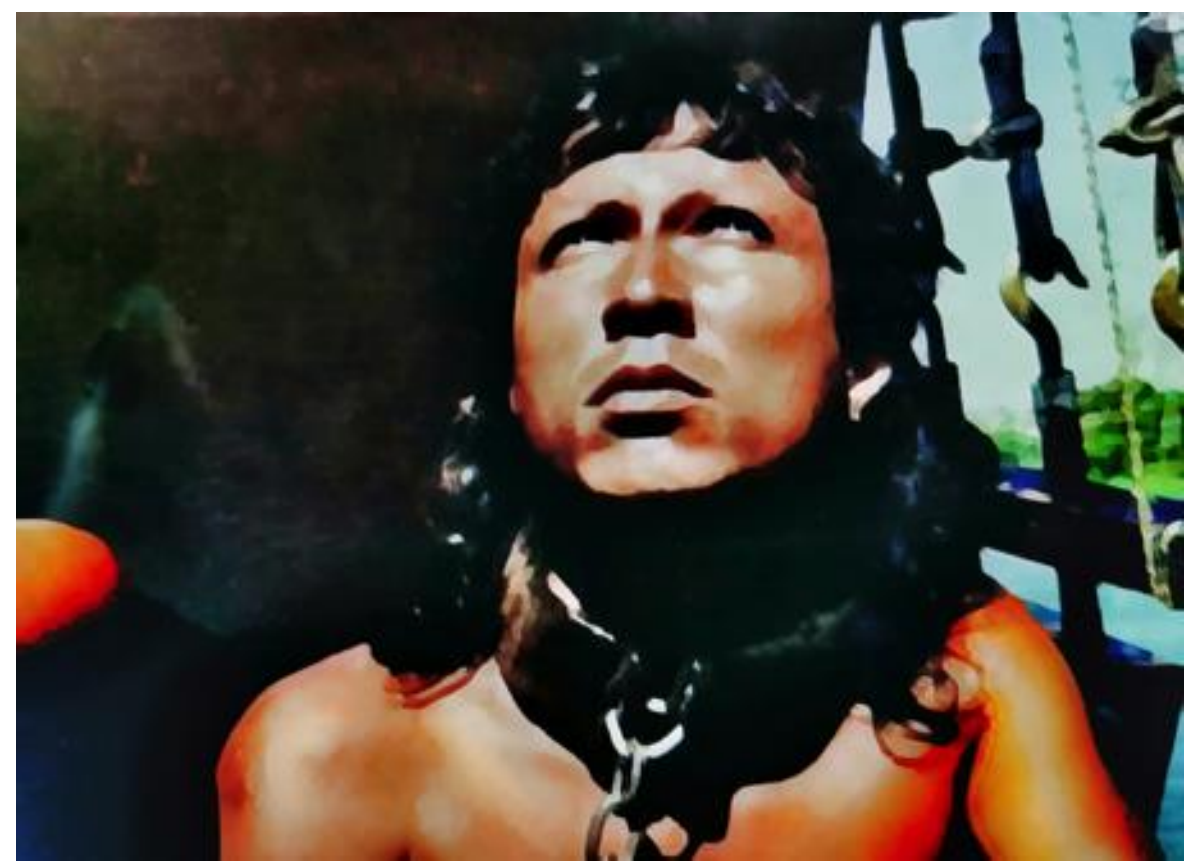


56 - O mergulho premeditado de Ajuricaba nas águas do Rio Negro.

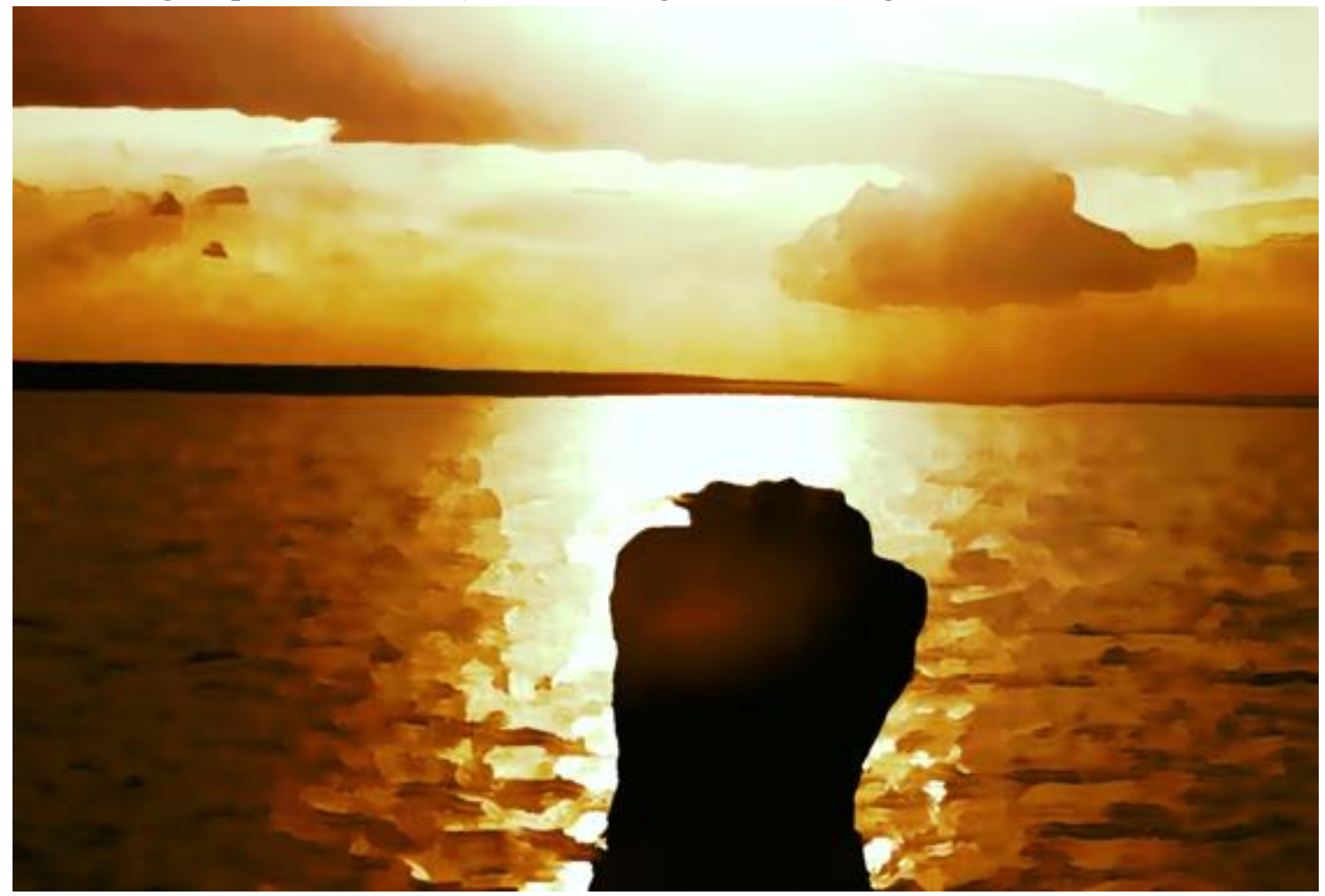

57 - "Eu te mato índio, eu te mato! Nem que tenha que beber toda a água deste rio, beber todas as nuvens deste céu, queimar todas as árvores desta mata. Não há de sobrar um peixe, um pássaro, um animal sequer para contar a sua história".

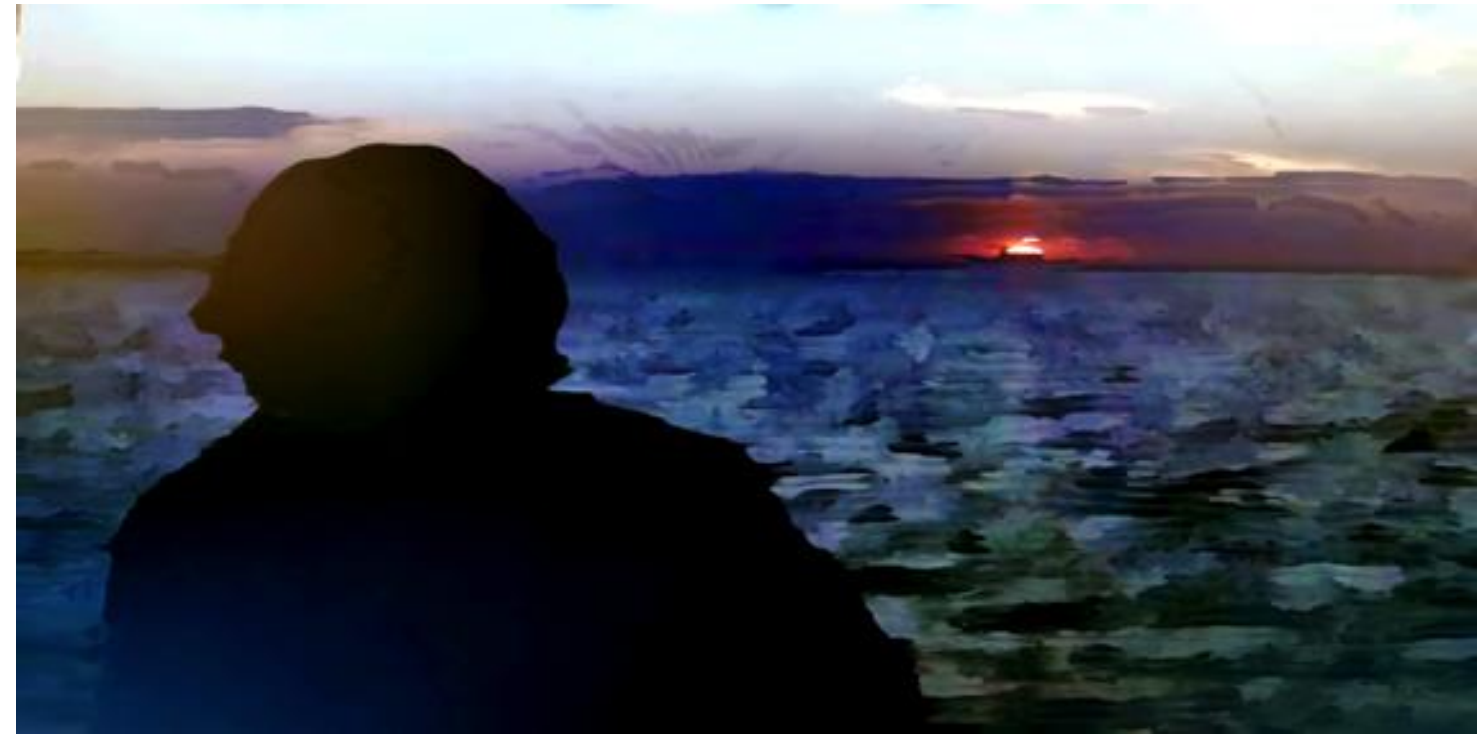

58 - "Eu tenho que mergulhar repetidamente na água da dúvida".

59 - "Hypotheses non fingo".

60 - "Não há nada de hipotético no que liga a proposição ao fato".

61 - "O essencial de uma hipótese é que ela suscita uma expectativa, ao admitir uma confirmação futura. Ou seja, é da natureza de uma hipótese que sua confirmação nunca termine. Quando digo que uma hipótese não é definitivamente verificável, isso não 
significa que haja uma verificação dela da qual possamos nos aproximar sempre mais sem nunca alcançar. Isso é um contrassenso. Não! Uma hipótese estabelece com a realidade uma relação formal diferente da verificação. (É claro que as palavras verdadeiro e falso também não são aplicáveis aqui ou então têm outro significado. A natureza da crença na uniformidade dos acontecimentos talvez fique mais clara quando tememos aquilo que esperamos que aconteça. Nada poderia persuadir-me a colocar a minha mão no fogo, embora seja somente no passado que me queimei. [...] Uma hipótese é uma regra para formar expectativas".

62 - "Toda explicação já é uma hipótese. E a explicação não é aqui, de nenhum modo, o que satisfaz. Quando Frazer começa a nos relatar a história do rei do bosque de Nemi, ele o faz num tom que mostra que ele sente, e nos quer fazer sentir, que aqui ocorre algo de estranho e temível. Mas a pergunta 'por que isso ocorre?' só pode ser respondida, na verdade, assim: porque isso é temível, grandioso, horripilante, trágico etc.; não menos do que trivial e insignificante, isso gerou esse acontecimento".

63 - "O batismo como lavagem. - Um erro se produz, antes de tudo, quando a magia é interpretada cientificamente. Se a adoção de uma criança ocorre de modo que a mãe a retira do seu vestido, então, é insano acreditar que existe aqui um erro e que ela acredita ter dado a luz à criança". 64 - "Que estreiteza da vida mental da parte de Frazer! E que impossibilidade de conceber uma outra vida diferente da inglesa do seu tempo! Frazer não consegue pensar em nenhum sacerdote que não seja, fundamentalmente, um pároco inglês do nosso tempo, com toda a sua estupidez e debilidade. [...] A apresentação que faz Frazer das concepções mágicas e religiosas dos seres humanos é insatisfatória: ela faz com que essas concepções apareçam como erros. Estava, então, Agostinho errado quando invocava a Deus em cada página da Confissões? E se ele não estava errado, então, quem estava, poder-se-ia dizer, era o santo budista - ou outro qualquer - cuja religião expressa concepções completamente diferentes. Mas nenhum deles estava errado. Exceto quando afirmava uma teoria".

65 - "Pensei que eles iam dar graças a Deus quando fossem ver a civilização chegar. Ora, eles são atrasados e nós somos modernos. Só sairiam lucrando aprendendo conosco. Mas não. Eles nos hostilizam sempre".

66 - "E daí, a cultura mais primitiva é sempre uma cultura adulta e, por isso mesmo, incompatível com as manifestações infantis que se podem observar na mais evoluída civilização".

67 - “- Traga uma toalha para o capitão! - Então o filho da puta me traiu? - Traga um vinho para todos! - Mandei juntar todas as queixas, as devassas, os textos jurídicos contra Ajuricaba. E de acordo com a lei régia, pedi que a guerra fosse declarada justa, para desencargo de consciência e diminuição de responsabilidade. Convoquei uma junta de missões religiosas. Todos não só consideraram justa, mas de obrigação a guerra contra os maiapenas e manaós de Ajuricaba. O próprio bispo que votou posteriormente recomendou a luta. Apenas o reitor do colégio dos jesuítas aqui presente votou contra. Por uma questão de consciência, senhor governador. O governador bem sabe que uma cobiça desmedida marcha sempre à frente dessas missões ditas civilizatórias. Aliás, uma cobiça de tal modo desmedida, que o próprio monarca de Lisboa solicitou ao governador Costa Freire que tomasse cuidado e procurasse evitar maiores contratempos que pudessem comprometer o bom nome do Estado e da religião. - Mas o senhor também não ignora que mal chegava de volta o nosso Belchior com a palavra desse infiel, insolente e rebelde 
Ajuricaba de que haveria paz no Rio Negro, e ele volta a conduzir centenas de selvagens contra as posições portuguesas, castigando os nativos, nossos aliados. Finalmente viram que esse nativo, que nos infligiu derrotas, durante tantos anos, não passava de um traidor. - E a quem ele traiu? O senhor sabe, por acaso, o que significam para ele países como Inglaterra, Espanha, Portugal, Holanda? Nada! Absolutamente nada! As suas nações são outras: barés, manaós, maiapenas. [...] A sua nação ele não traiu! Muito pelo contrário. Foi para evitar a fúria homicida que se estendia sobre os seus irmãos que ele entrou na guerra". 68 - “- Você não é religioso? - Sou, mas isso é diferente. - Diferente como? - Não sou fanático como você. - Eu também não sou. - Então, por que pulou para pegar a cruz? Não sei. - Mas... foi uma forma de... provocação? - Isso! Foi uma provocação. - Sério? Eu não entendo. Você acha que a polícia não tem mais nada a fazer, além de perder tempo com o seu salto pela cruz? - Primeiro, eu peguei a cruz. Segundo, eu concordo com você. Há muito mais coisas com que se preocupar".

69 - A cruz de pão e de vinho resgatada por Petúnia.

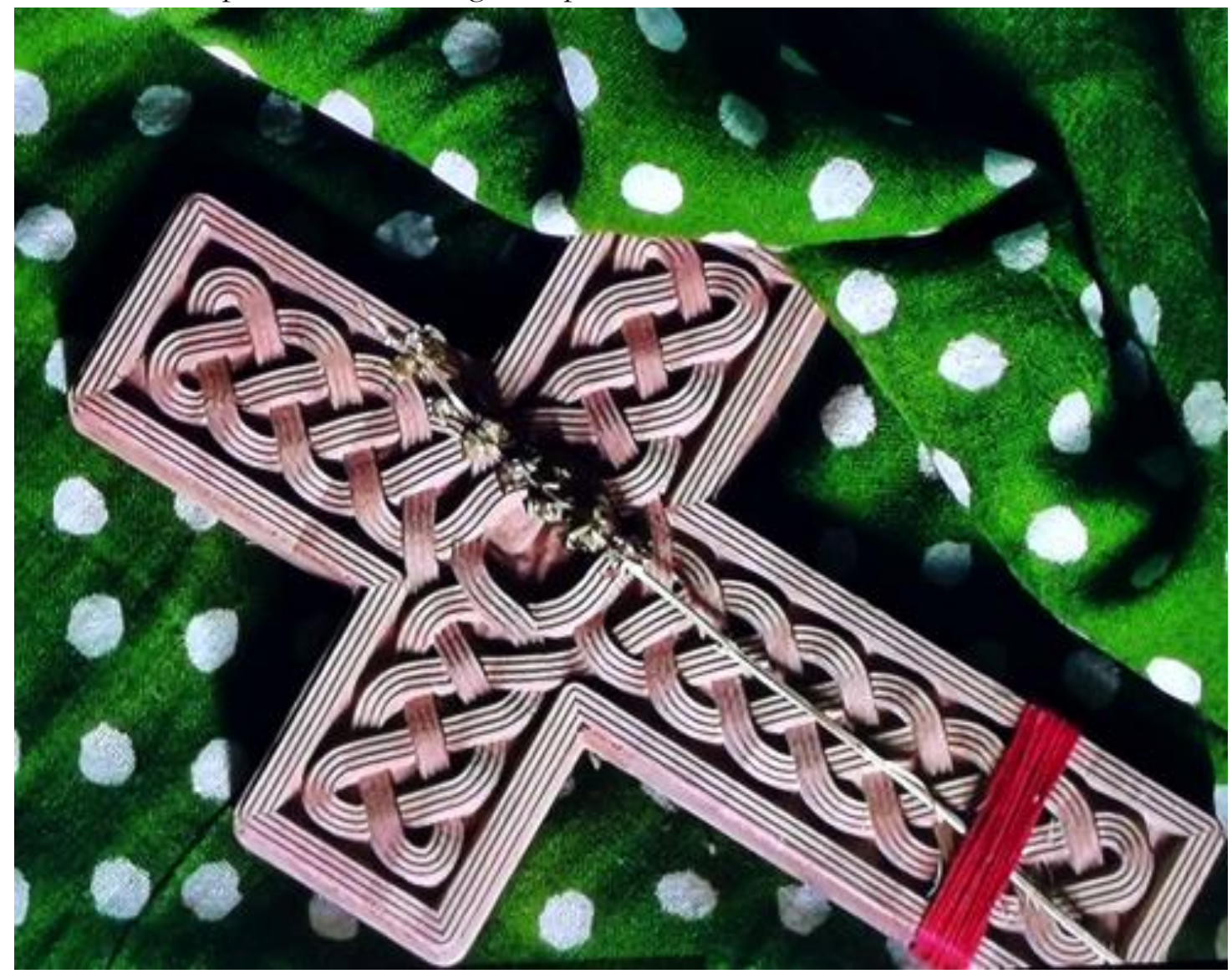


70 - Petúnia com a cruz sobre o peito nu.

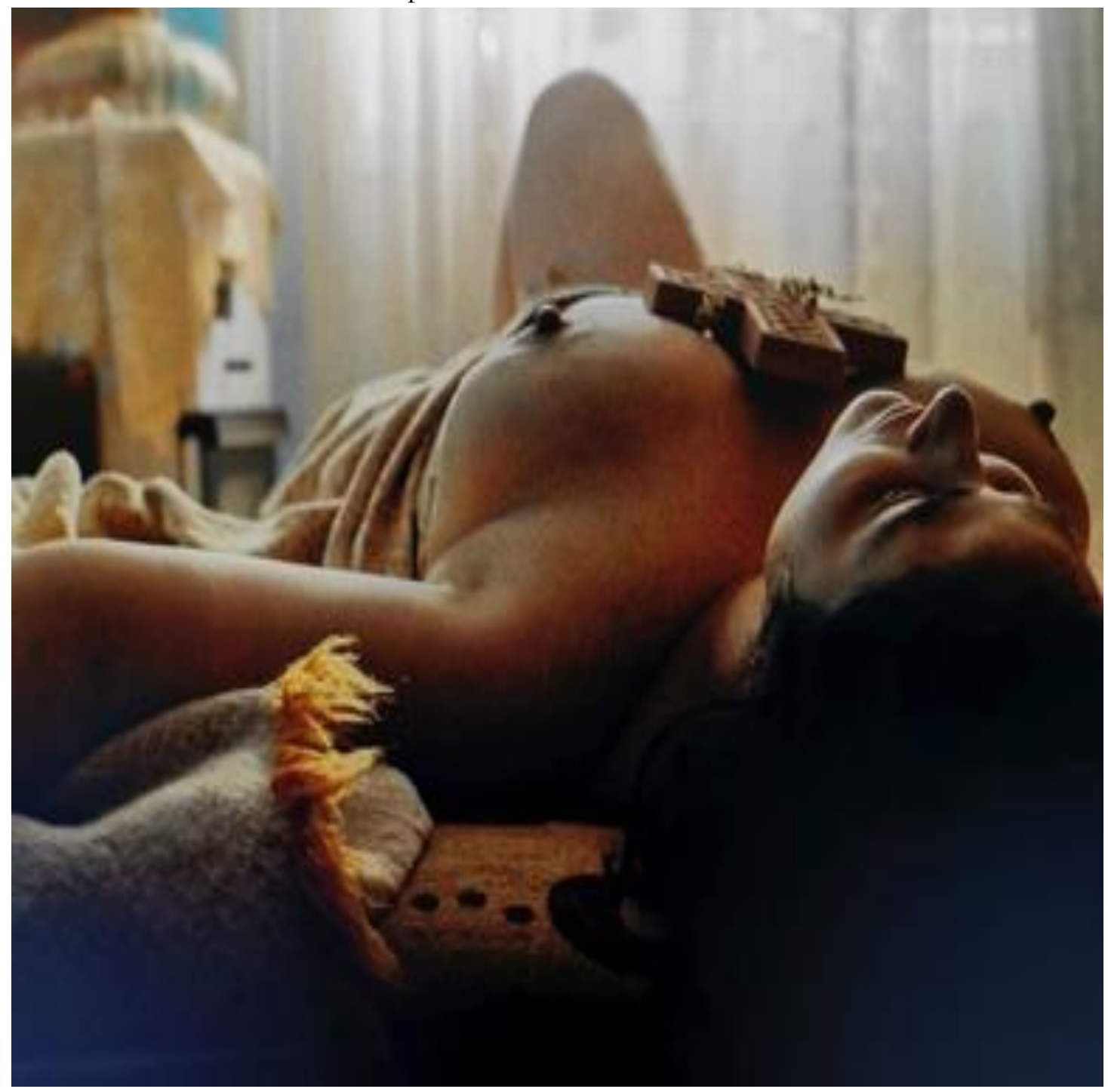

71 - “- Aquela mulher é Lúcifer! Ela roubou a cruz! - Deixe-me explicar. Deus disse que roubar é pecado, certo? Ladrões eram apedrejados. - E massacrados. - Isso! - Não sairemos daqui até que ela devolva a cruz. - Ela roubou, queremos de volta! [...] Era uma vez, em um reino distante, uma princesa. Ela era esnobe e mimada, uma solteirona arrogante e frustrada. Vaca! Vagabunda! Você roubou a cruz. Vai apodrecer no inferno!”. 
72 - Maria Madalena e seu xale da cor de vinho, cor e bebida estas que, na liturgia católicocristã, simbolizam o sangue de Cristo.

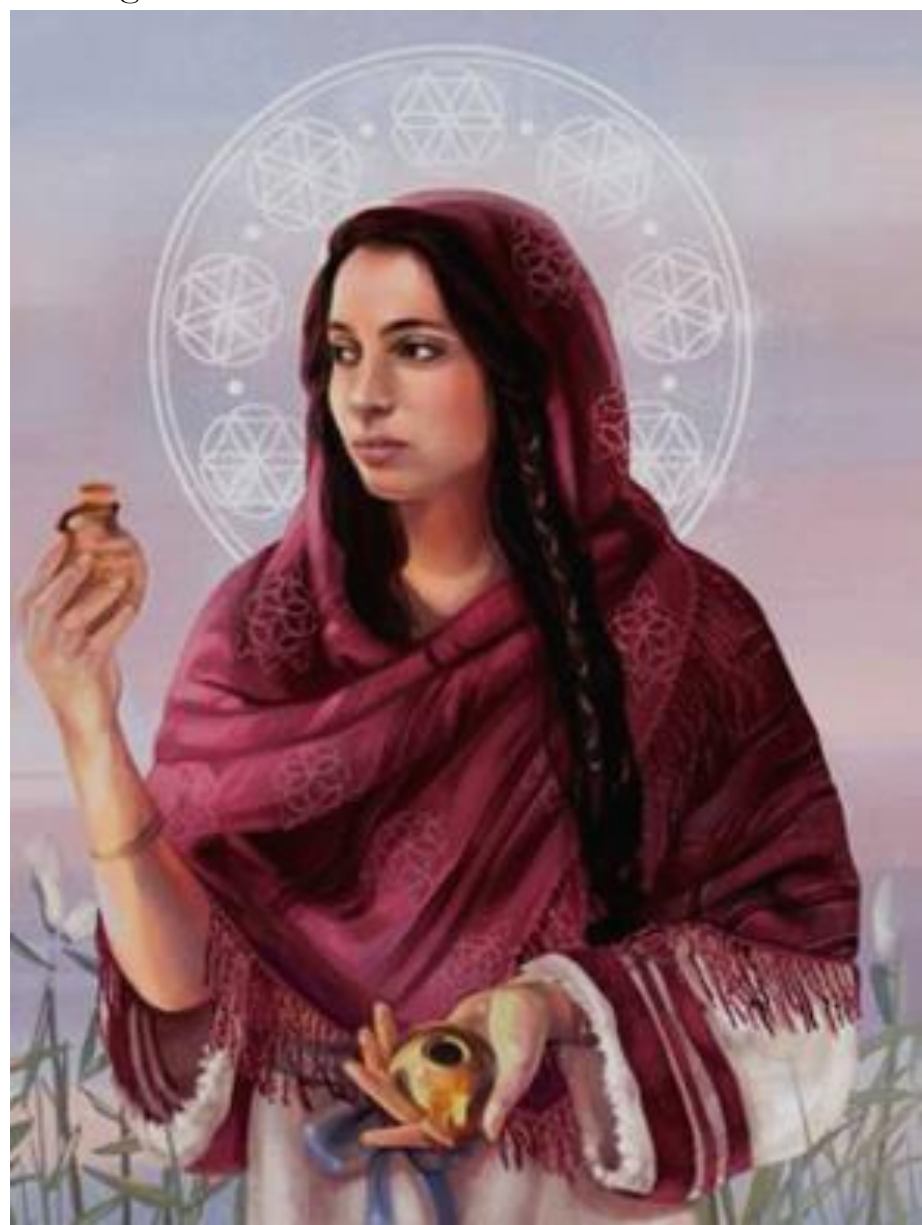

73 - O apedrejamento de Santo Estêvão.

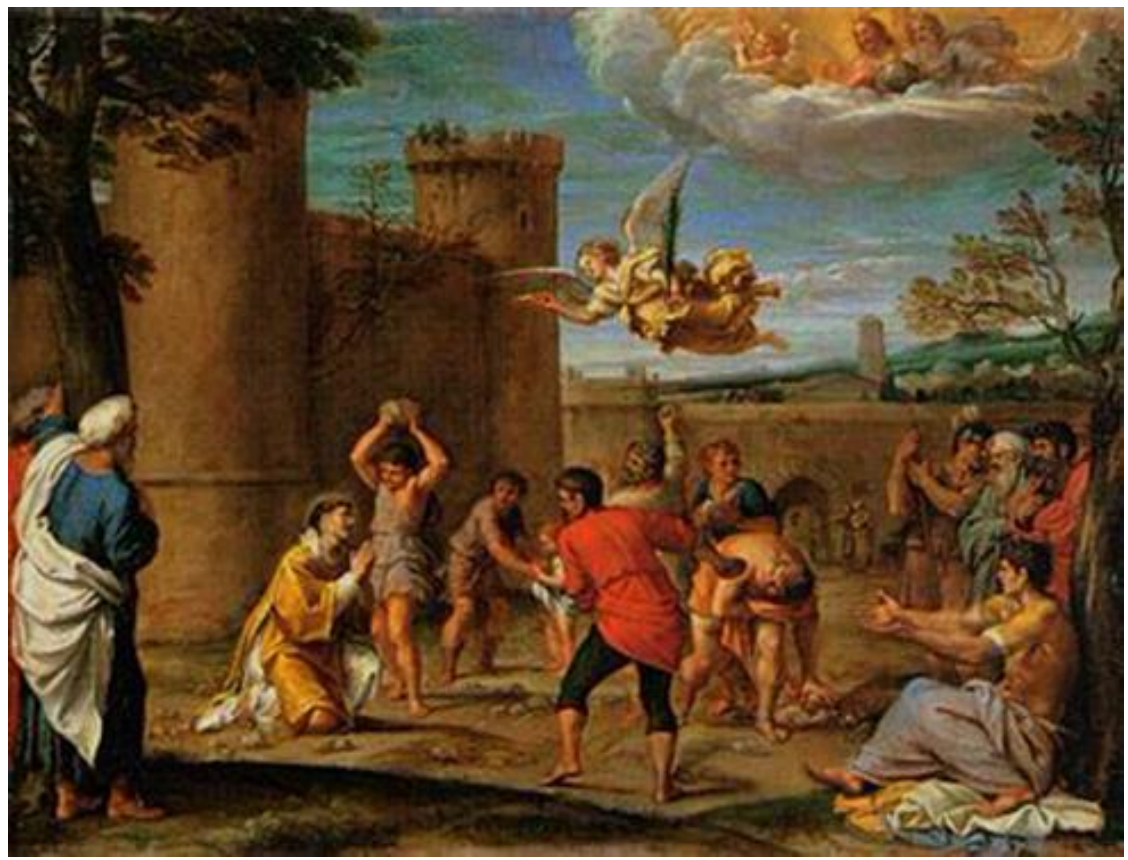


74 - E se Deus fosse mulher? É 2018, mas ainda parece a Idade das Trevas na Macedônia. Talvez por isso chamam o nosso país de "eterno". Eternamente presos na sombria Idade das Trevas.

75 - (Re)conhece-te a ti mesmo? Ajuricaba virou Píton e Píton virou Petúnia que, por sua vez, virou Ajuricaba: cantos de musas, vapores alucinógenos e predições do futuro.

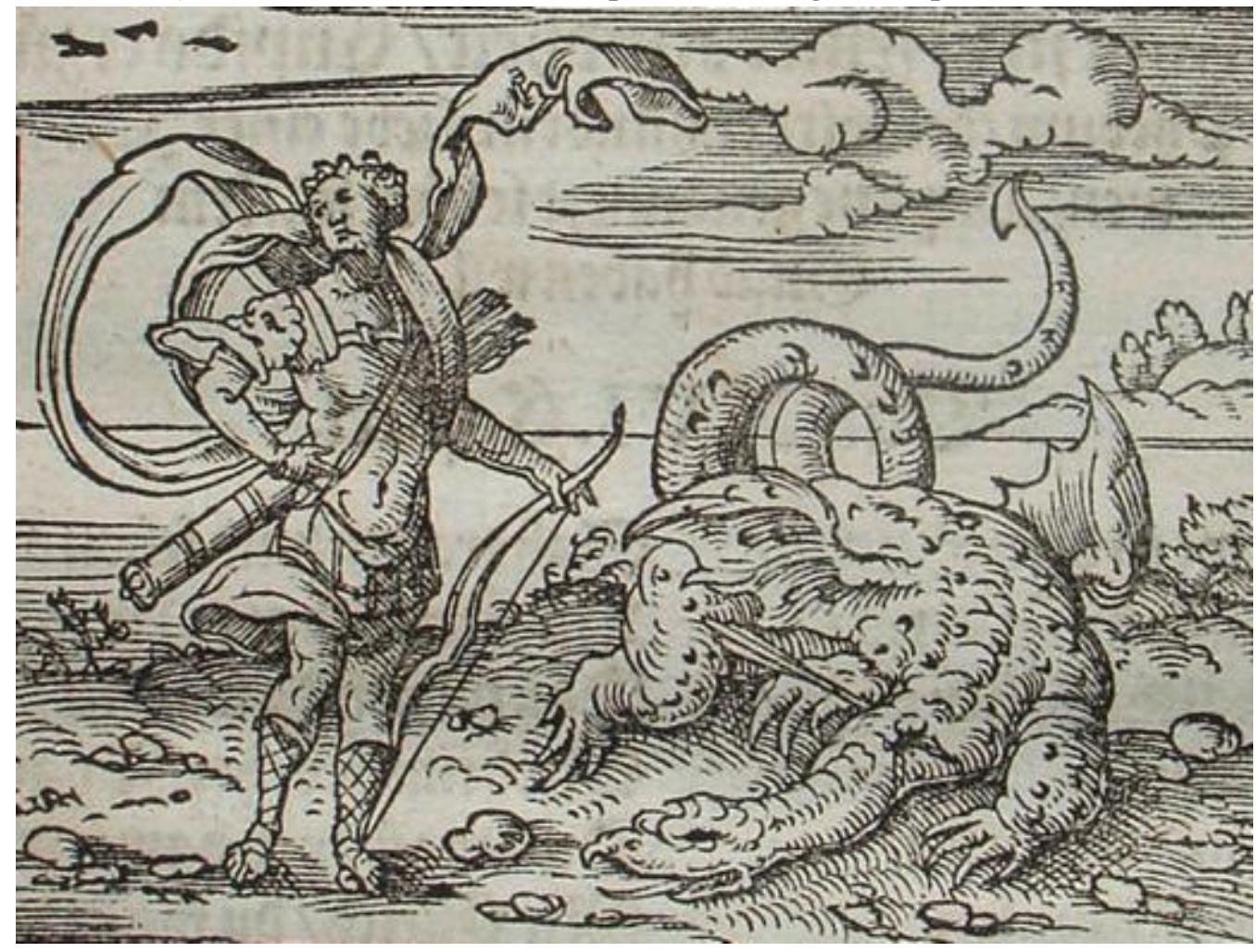

76 - Deméter, sementes e serpentes.

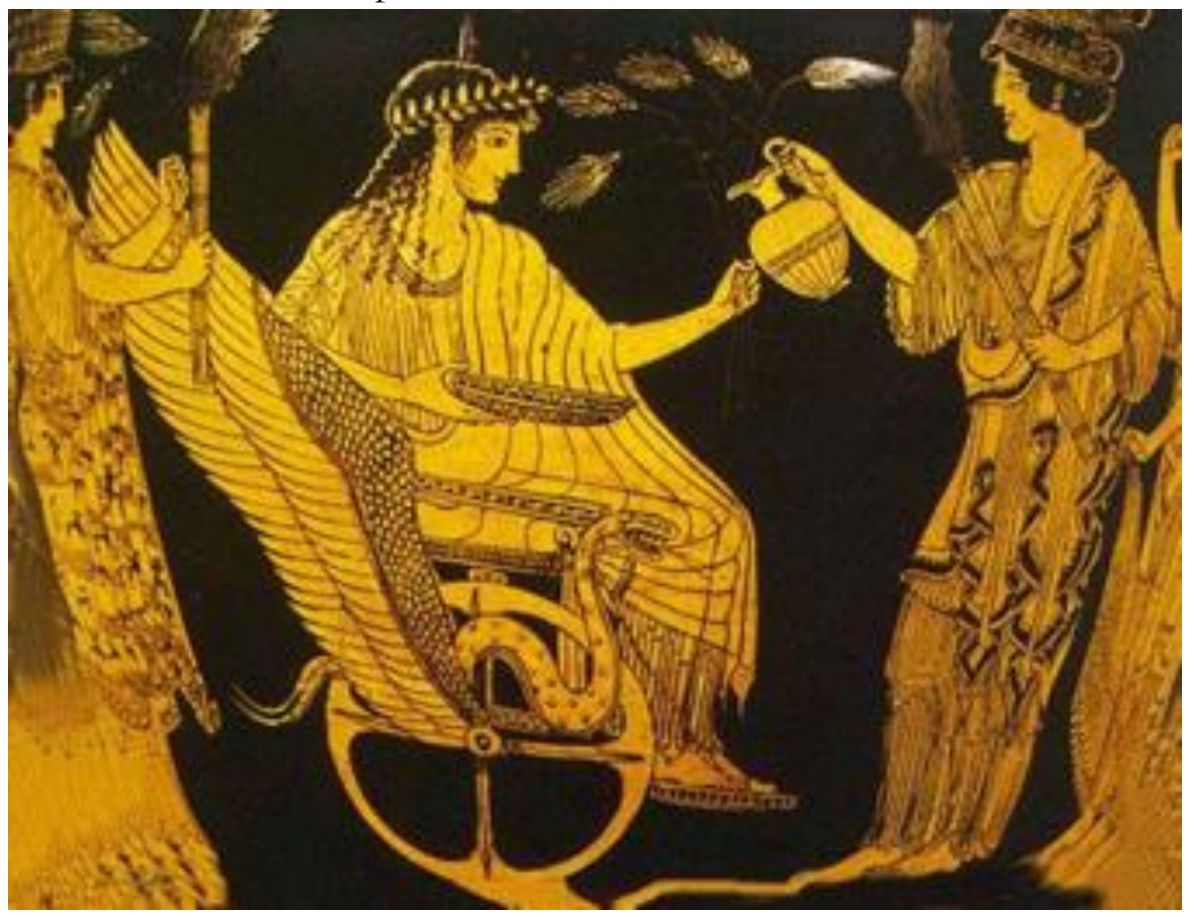


77 - "Então Deus disse à serpente: és maldita entre todos os animais domésticos e todas as feras selvagens. Caminharás sobre teu ventre e comerás poeira todos os dias de tua vida".
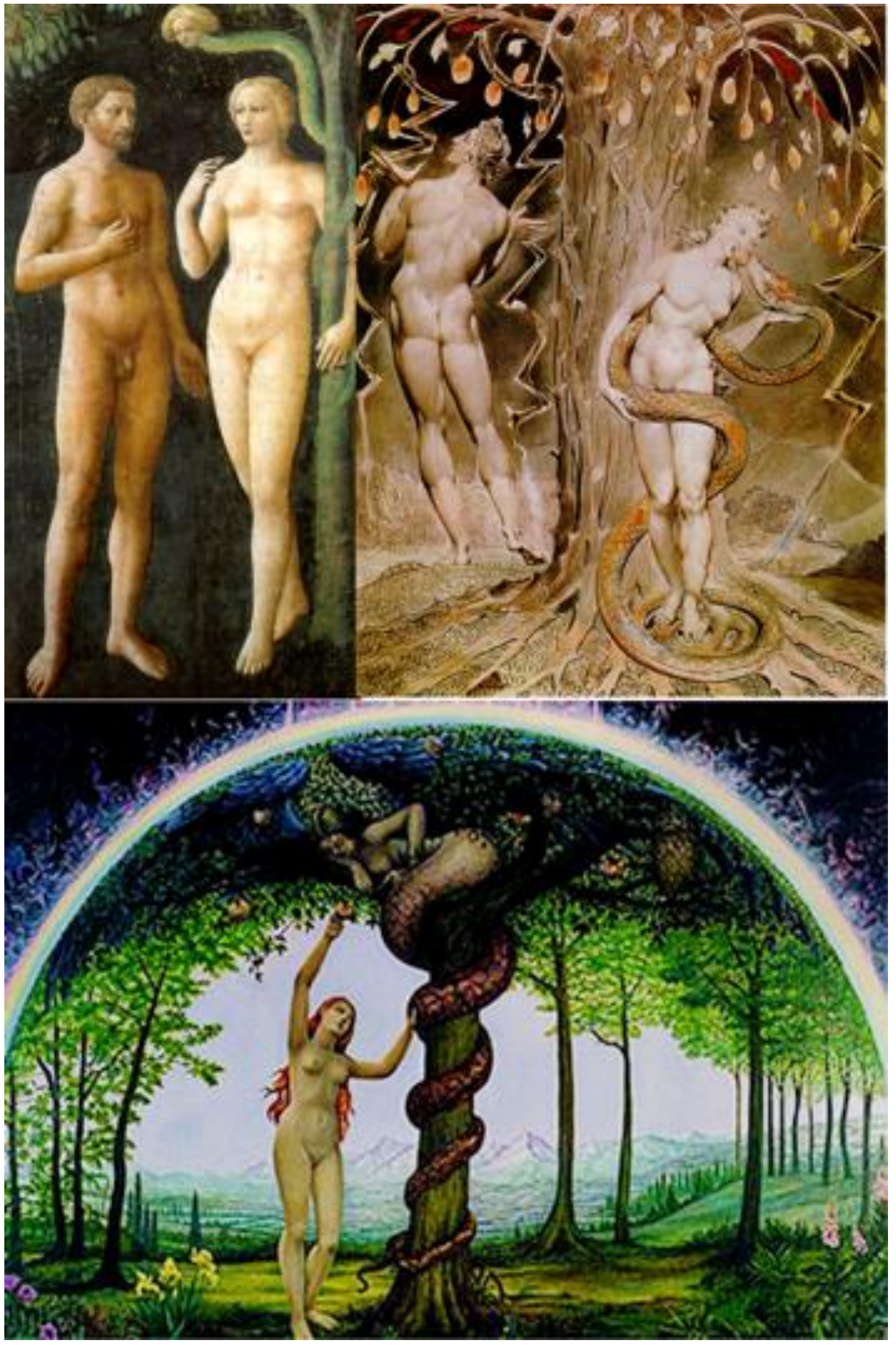
78 - Mulheres, inferno, demônios e serpentes na arte sacra copta.

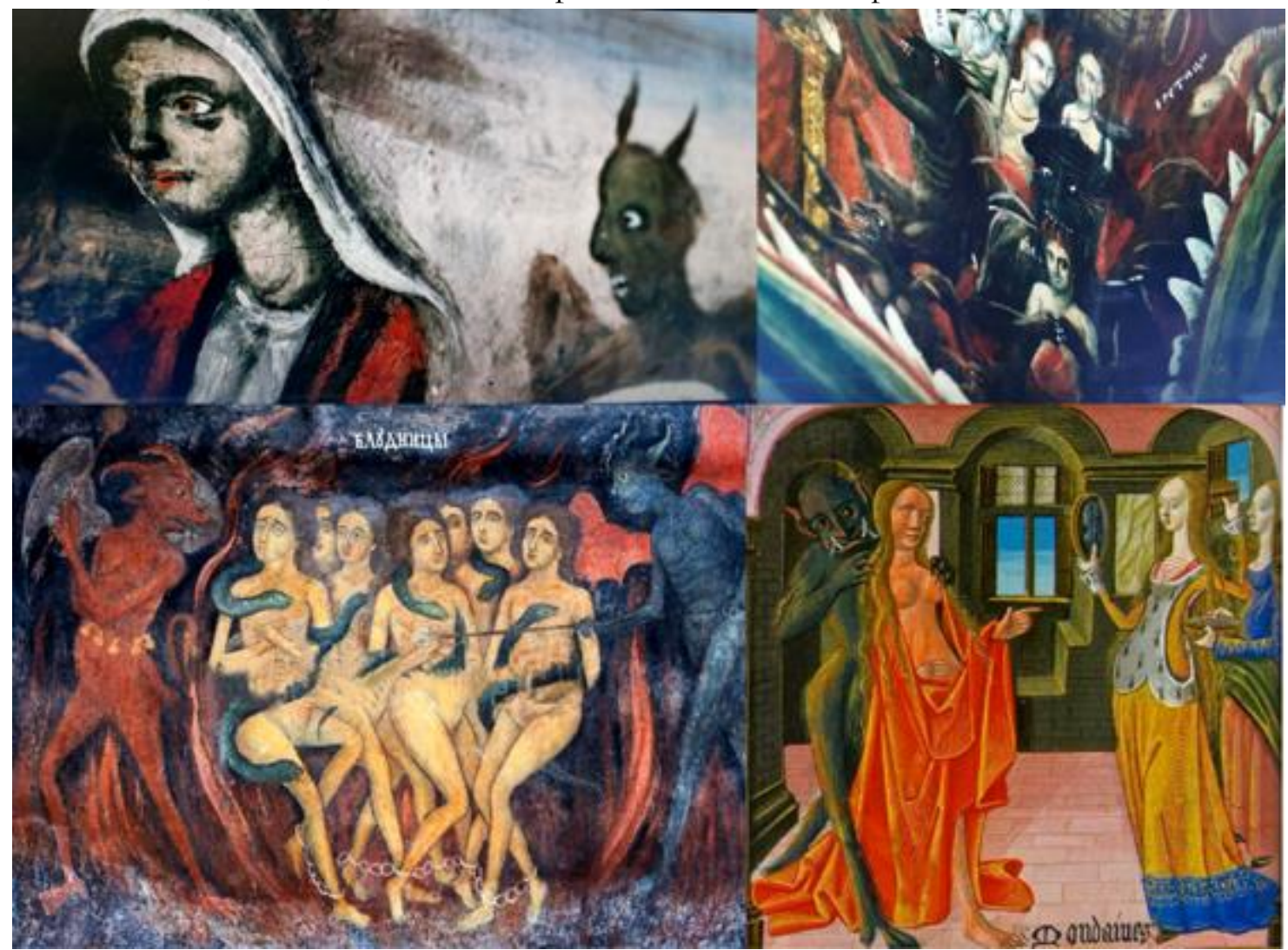

79 - “- Senhores! Já não há mais ameaças. O rio Negro está aberto outra vez. Impusemos um sério castigo aos rebeldes. E logo os demais cederam às nossas exigências. Os temíveis manaós que ostentavam antigamente a bandeira holandesa em seus barcos carregam agora a bandeira de nossa pátria. São dos selvagens estas pequenas lembranças. - Eles se pintam com urucum, afiam os dentes, deformam as orelhas e os beiços? - São nossos patrícios, senhora. - Mas o capitão não acha verdadeiramente que povos civilizados possam ser patrícios dos que vivem em choças imundas, nús, todos misturados, falando aquelas línguas ridículas. - Não se deve levar a sério tudo o que o capitão fala. Não são civilizados como não são civilizáveis. Nem nossos serviçais, os caboclos, consideram os índios seus patrícios". - É verdade que os animais também são criaturas de Deus. Mas existem os coiotes que ameaçam as ovelhas e a obrigação do bom pastor é proteger seu rebanho. - Mas agora os lobos estão à solta e serão dominados a pulso de ferro, senão nenhuma família poderá construir em paz uma vida cristã naquelas matas".

80 - "Vira cobra que eu quero ver! Vira peixe, vira! Vira pássaro! Quero ver você voar!".

81 - “- Pegue isto! [O policial Darko oferece uma jaqueta a Petúnia para protegê-la do frio]. - Você acha que eu deveria falar com ela? - Com ela quem? - A jornalista. - Não sei. Todos gostam de ver TV. Pode ser de grande ajuda. - Você acha que preciso de ajuda? - Sinceramente eu não sei. - Nunca quis causar problemas. - Isso não importa. Não é da minha conta. - Você é sortudo. Tem um emprego e tudo. - Sortudo? Já viu com quem trabalho? Eu queria... ter a sua coragem... [Pausa prolongada] - Não foi coragem... Eu pulei sem pensar. Como um animal. - Como o quê? - Eu me sinto... Eu me sinto um animal... - Vista isto [O policial Darko oferece uma jaqueta a Petúnia], para não morrer de frio". 
82 - "O elo com o passado era de vidro e se quebrou". O brasão da cidade de Manaus não é manaó.

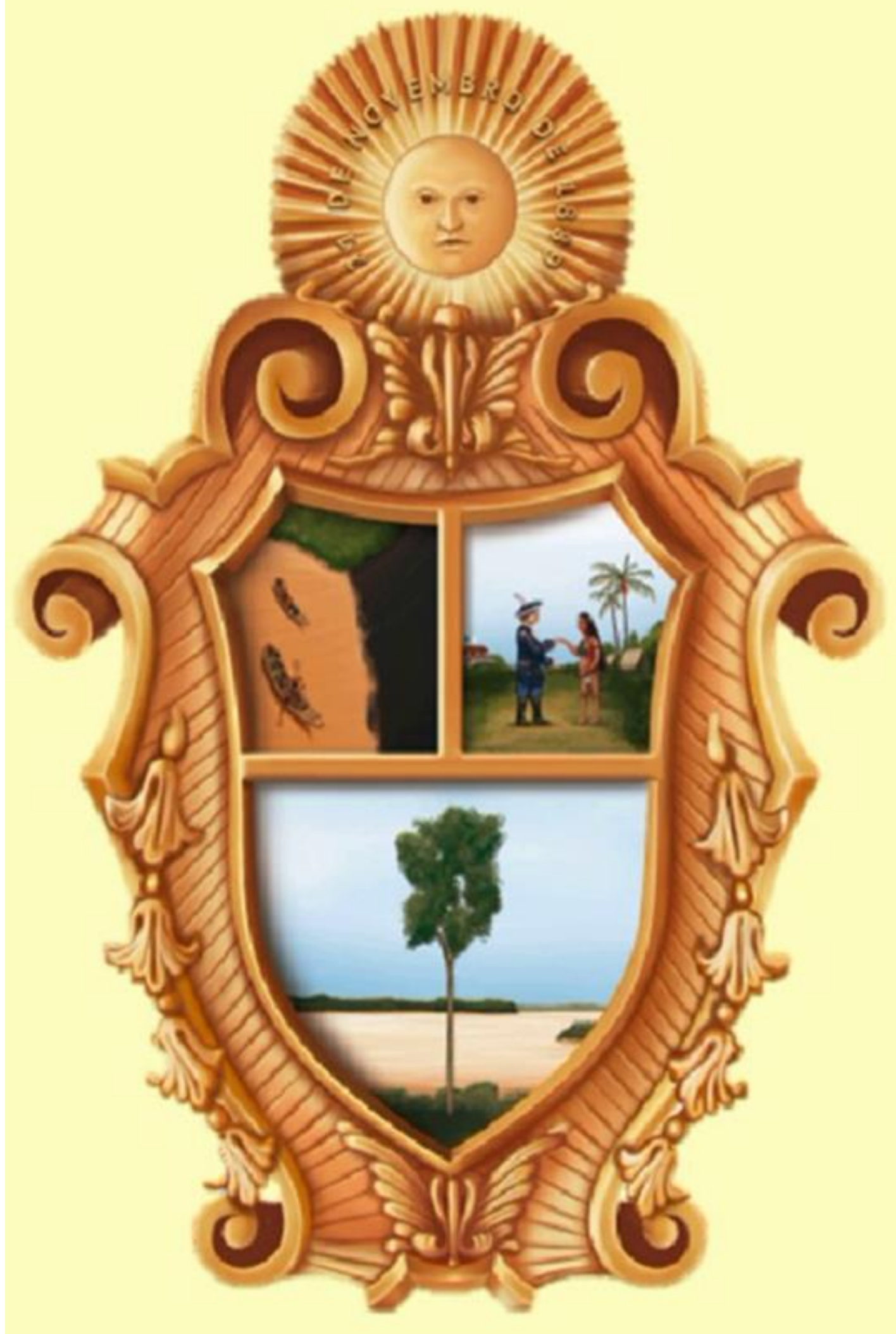


83 - Um brasão para os manaós: uma desconstrução terapêutico-antropofágico-decolonial dos jogos heráldico-imperialistas de linguagem dos colonizadores das terras de Abya Yala.

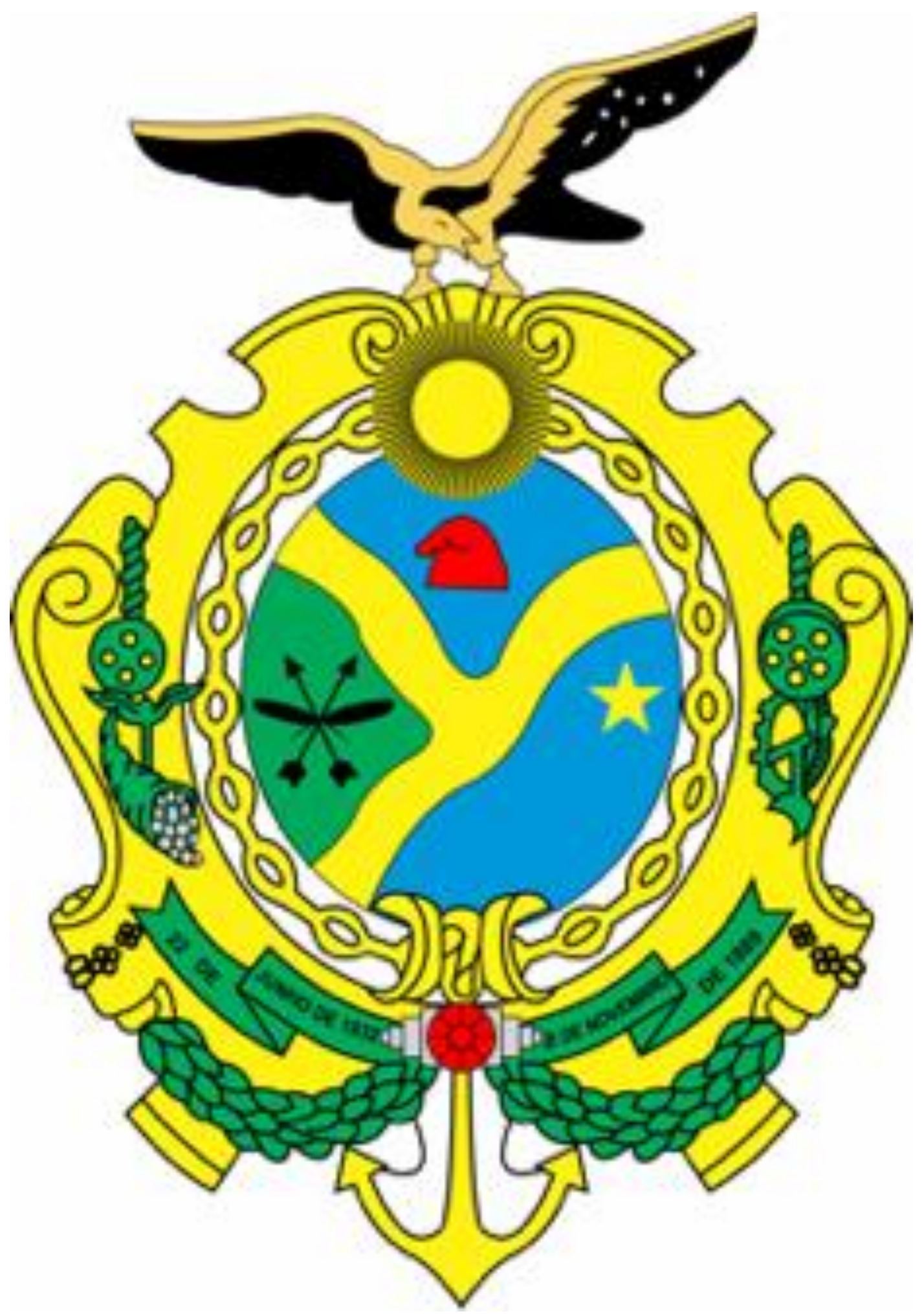




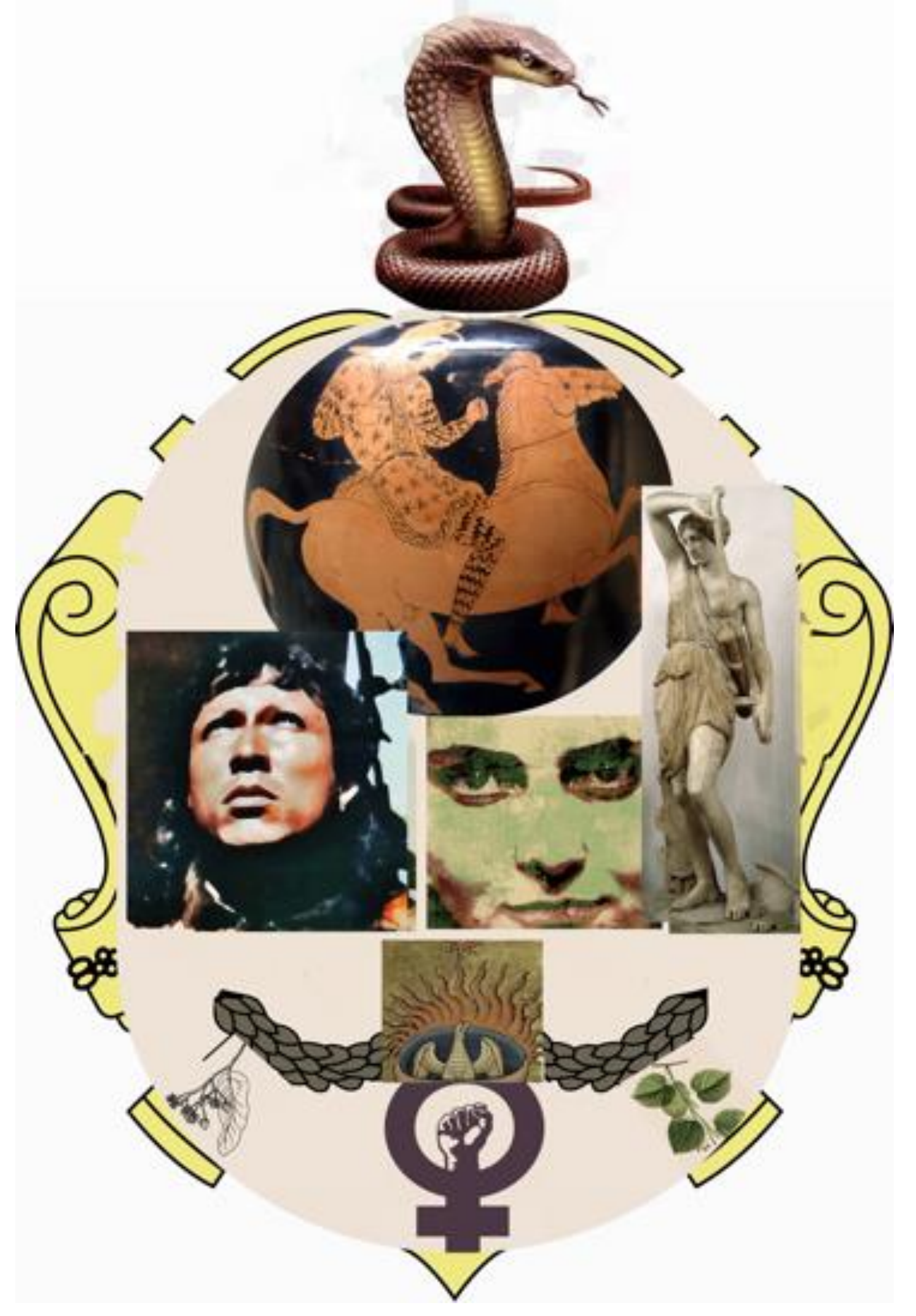


84 - "Indígenas tumbaron la estatua del conquistador español Sebastián de Belalcázar en el suroeste de Colombia".

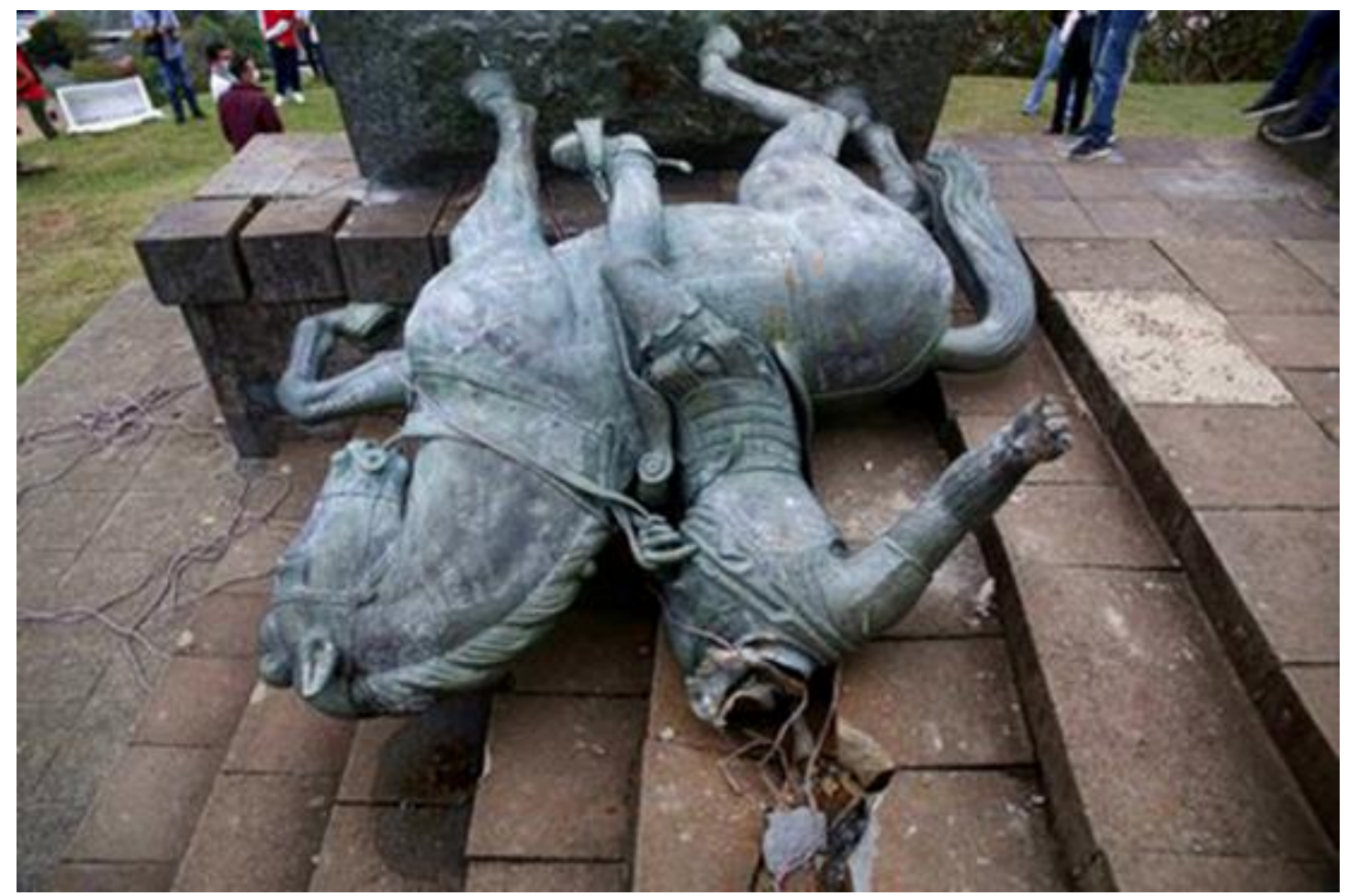

85 - "Manifestantes derribaron otra estatua de Cristóbal Colón en Baltimore".

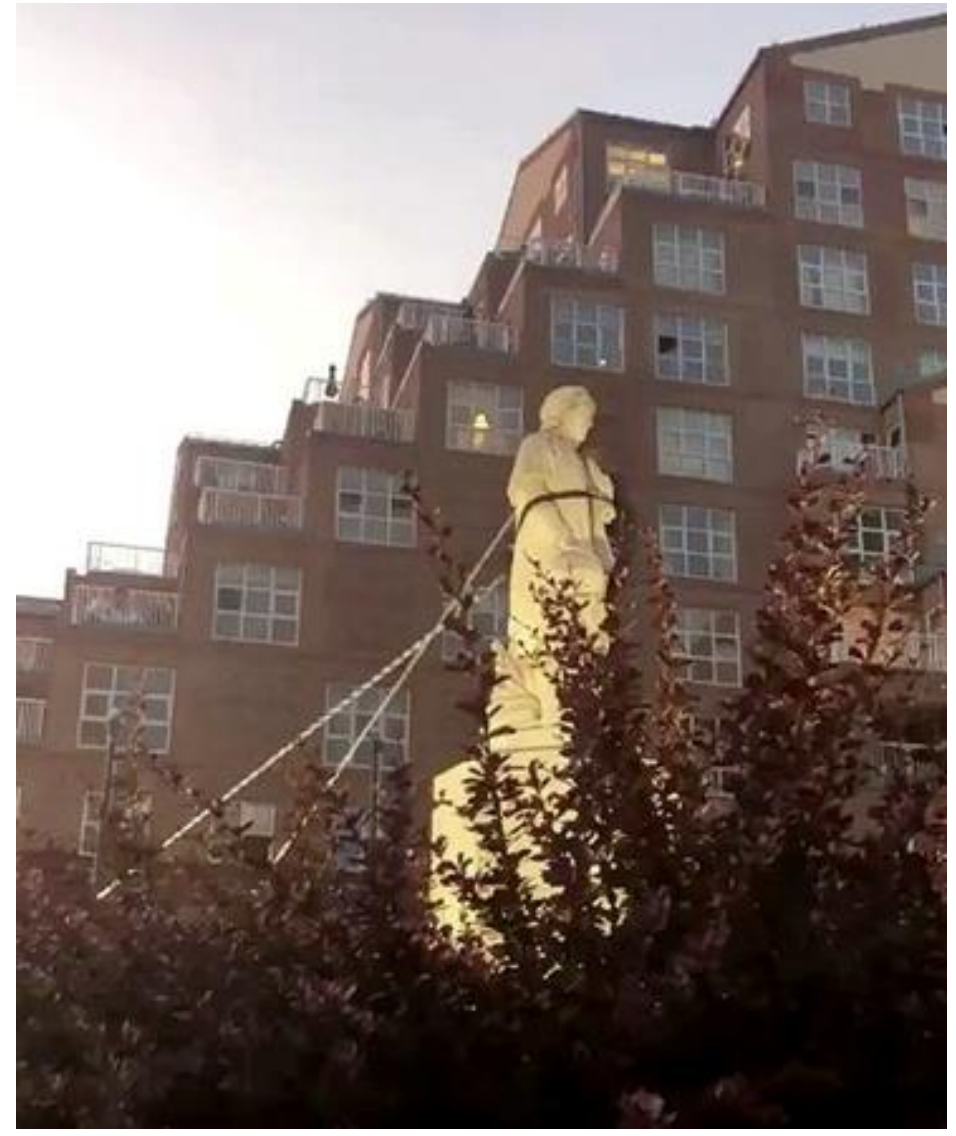




\section{NOTAS}

N1 - Foto por Antonio Miguel de cena do filme Deus é mulher e seu nome é Petúnia (MITEVSKA, 2019).

N2 - Este afresco monocromático, intitulado Occasio e Poenitentia (1500), do pintor e gravador italiano Andrea Mantegna (1431-1506) está conservado no Museu da Cidade São Sebastião em Mantova, Itália. Ele encena versos de um poema intitulado In simulacrum Occasionis et Peonitentia do poeta e professor de retórica latino Decimus Magnus Ausonius (310 d.C. - 395 d.C.): um homem se movimenta na direção de uma mulher - Occasio (Chance), a deusa do momento oportuno - como se desejasse pegá-la. Os olhos da deusa estão ocultos por uma longa mecha de cabelos que lhe cai da cabeça careca sobre o rosto, simbolizando o desconhecimento, por parte das pessoas, do momento oportuno de agir para se atingir metas desejadas. Nota-se também que Occasio possui asas no calcanhar do seu pé esquerdo que pisa sobre uma esfera, simbolizando a rapidez e a fugacidade do momento oportuno, daquele momento do pegar ou largar aquela mecha única de cabelos de uma mulher que se equilibra instavelmente, com um único pé, sobre a superfície da Terra de onde está prestes a cair e desaparecer para sempre. Embora o homem não queira deixar escapar aquele momento oportuno único e singular, ele está sendo impedido de avançar por uma outra mulher de nome Poenitentia, isto é, Penitência - que simboliza a virtude, a prudência e a moderação. Ela tem os seus os pés firmemente apoiados sobre um tablado quadrado, que simboliza a estabilidade, e o ato de dificultar o movimento do homem em direção à deusa Occasio simboliza a sua recomendação para que ele não se deixe seduzir pelas tentações fugazes dos prognósticos da sorte, do bom acaso.

Fontes: (https://it.wikipedia.org/wiki/Occasio_e_Poenitentia);

(https://it.wikipedia.org/wiki/Occasio_e_Poenitentia);

(http://dictionnaire.sensagent.leparisien.fr/Occasio $\% 20 \mathrm{e} \% 20$ poenitentia/it-it/);

(https://it.wikipedia.org/wiki/Andrea_Mantegna).

N3 - A imagem à esquerda é uma réplica da estátua da deusa grega Tique (ou Tyche) produzida pelo escultor Eutiquides (final do século IV a.C., discípulo de Lísipo, que se encontra na Galleria dei Candelabri 49 no Vaticano em Roma. No catálogo do Museu de Arqueologia Clássica da Universidade de Cambridge, encontra-se a seguinte descrição desta escultura: "A divindade protetora da cidade. Cópia romana reduzida de um original em bronze. Esta escultura é repleta de símbolos e metáforas. A figura feminina da deusa grega Tique representa a sorte ou a boa sorte para os habitantes da cidade de Antioquia, na Turquia moderna. Ela está sentada sobre uma rocha, empurrando, com o seu pé direito, uma figura masculina nadadora, que personifica o rio Orontes, para dentro das águas desse rio. Rocha e rio são símbolos da topografia da cidade de Antioquia. Com a sua mão direita, a deusa segura um ramo de trigo, representando prosperidade, e carrega em sua cabeça uma coroa dourada com a forma de uma torre que, na cultura helenística, simbolizava a segurança, a proteção, o poder e a riqueza de uma cidade, razão pela qual Tique era conhecida, entre os romanos, como a deusa Fortuna. Esta coroa mural (corona muralis) passou, posteriormente, a ser usada como um símbolo de poder imperial e imperialista do Império Romano, uma 
vez que passou a ser usada como uma condecoração militar dada ao primeiro soldado que, após a invasão de uma cidade pelo exército romano, conseguisse escalar a muralha que cercava a cidade e lá colocasse o estandarte representativo do Império. Nos primeiros tempos da civilização helenística, quando essa cópia foi feita (cerca de 300 a.C.), Antioquia (atual Antáquia, na Turquia) tornou-se a segunda maior cidade do leste do Mediterrâneo, sendo a primeira, a cidade de Alexandria. Naquela época, muitas outras cidades adotaram Tique como seu símbolo".

Fonte: (https://museum.classics.cam.ac.uk/collections/casts/tyche-antioch).

Já a imagem à direita é uma estátua em mármore - esculpida por um artista romano anônimo, no século I d. C. - de Livia Drusila ou Julia Augusta (59/58 a.C - 29 d.C.) - a terceira esposa do imperador romano Augusto (63 a.C. - 14 d.C.) - retratada como Ops, a deusa grega da abundância e da fertilidade, segurando um ramo de trigo em uma das mãos e uma cornucópia na outra. A comunidade católico-ortodoxa do filme de Mitevska (2019) prega um tipo particular de cristianismo católico que se instituiu, em 1918 - juntamente com a criação do Reino da Iugoslávia, instituído para se cuidar da pequena comunidade de cristãos macedônios convertidos ao catolicismo -, sob a denominação Igreja Greco-Católica da Macedônia, ou então, Igreja Católico-Bizantina da Macedônia, uma igreja católica sui iuris ou sui juris, isto é, uma igreja relativamente autônoma da católico-romana, dado que embora esteja sob a autoridade suprema do pontífice romano, ela goza de autonomia tanto no que diz respeito à manutenção de seus ritos litúrgicos orientais tradicionais, quanto de gestão e controle de seu patrimônio material e religioso. Essa autonomia está garantida pelo Codex Canonum Ecclesiarum Orientalium (Código de Cânones das Igrejas Orientais - CCEO 27) promulgado, em 1990, pelo Papa João Paulo II (1978-2005), Karol Józef Wojtyła (19202005), e que se aplica às 23 igrejas católicas orientais da igreja católica. O seu rito litúrgico é de tradição bizantina e, portanto, proximamente conectado com os primitivos ritos litúrgicos cristãos da cidade cosmopolita de Constantinopla - que foi capital do Império Romano do Ocidente (330 d.C. - 395 d.C.) e capital do Império Bizantino ou Império Romano do Oriente (395 d.C. - 1204 d.C.; 1261 d.C. - 1453 d.C.) -, e remotamente conectado com os rituais religiosos politeístas da Grécia Antiga, dado que a cidade de Bizâncio, atual Istambul, na Turquia - renomeada Constantinopla quando, no ano de 330 d.C., se tornou a capital do Império Romano por ato do Imperador Constantino -, foi fundada, por volta de 657 a.C., por colonos gregos da cidade-estado de Mégara.

Fontes: (https://es.wikipedia.org/wiki/Ops);

(https://pt.wikipedia.org/wiki/Coroa_mural);

(https://pt.wikipedia.org/wiki/Igreja_Greco-Católica_Macedónica); (https://pt.wikipedia.org/wiki/Sui_iuris);(https://pt.wikipedia.org/wiki/Rito_bizantino) (https://pt.wikipedia.org/wiki/Código_dos_Cânones_das_Igrejas_Orientais).

N4 - Citação extraída de SLATER (1994 p. 773). Observe-se que, nesta fala de um garimpeiro da região amazônica denominada Paramarimbo, pertence ao Suriname - local de grande extração de ouro na década de 90 -, a mulher está relacionada à fartura, à prosperidade e ao acaso, o que faz com que a ela seja confiado o papel de guia para encontrar ouro nas terras amazônicas. Uma mulher com traços de deusa guia e conduz o homem ao encontro do ouro amazônico, apontando para ele o caminho da sorte, da fartura 
e da prosperidade. Mas o segredo para este caminho deve ser mantido no sigilo, e apenas ser compartilhado entre eles.

N5 - A imagem é a de uma cacique-mulher-de-ouro esculpida por indígenas da época préhispânica. Ela se encontra no museu do ouro em Bogotá (Colômbia). Sobre esta escultura o museu não registra informações mais detalhadas.

Fonte: (http://karolynechamiel.blogspot.com/2019/06/museo-del-oro-de-bogota.html).

N6 - A imagem à esquerda é a da bandeira do Reino de Portugal e Algarves sob o reinado de D. João V (1689-1750), que reinou de 1706 até o ano de sua morte, em 1750, sendo, portanto, o rei ainda entronado no ano de 1723, quando se dá o acirramento e confronto bélico final entre a coroa portuguesa e a comunidade indígena dos manaós, sob a liderança política de Ajuricaba. Como se vê, a bandeira é composta pela imagem de uma coroa dourada que coroa a cabeça do rei, simbolizada por um retângulo rubro ao longo de cujo perímetro se distribuem as imagens simbólicas de sete castelos dourados. Um chapéu em tecido púrpura se acopla à coroa, cujo aro é decorado com incrustações alternadas de pedras preciosas em verde-esmeralda e vermelho-rubi. Inscrito no retângulo rubro, há um retângulo branco com as imagens simbólicas de cinco escudos azul-marinho. Há, finalmente, volteando a cabeça e o pescoço do rei, simbolizados pelos retângulos, o colar dourado da Ordem de Cristo, do qual pende um pingente rubro em forma de cruz, à qual a imagem à esquerda dá destaque. A cor dourada, que predomina em relação às demais, expressa simbolicamente o propósito orientador da política colonialista-expansionista do império português, qual seja, o desejo do ouro que tanto extraiu e subtraiu de sua colônia ultramarina, mais gentil do que hostil, por eles nomeada Brasil, devido ao vermelho-brasa abrasador - a outra cor predominante da bandeira - das fibras internas do caule dessa árvore transformada em mercadoria pelos colonizadores. Esse expansionismo colonizador dourado foi premiado pelo papa com a concessão da dignidade de Patriarcado - uma circunscrição eclesiástica da Igreja Católica em Portugal - à cidade de Lisboa.

Fonte: Fonte: (https://pt.wikipedia.org/wiki/Evolução_da_bandeira_de_Portugal).

N7 - Fonte: (https://super.abril.com.br/blog/oraculo/por-que-o-pau-brasil-se-chamapau-brasil/).

N8 - Essa bandeira foi uma das duas primeiras que adentraram o solo americano no ano de 1492. Nela, em castelhano medieval, estão inscritas as letras iniciais dos monarcas católicos: F para Fernando, príncipe herdeiro da Coroa de Aragão, e Y para Ysabel, rainha da Coroa de Castela. Coroas douradas com nove cruzes douradas coroam tais letras iniciais dos nomes dos reis. Invasão da América. Expansionismo católico de caráter colonizador dourado. Tais letras em verde, uma de cada lado da cruz também em verde da ordem de Cristo, se inscreviam no pano branco da bandeira. A cor verde simbolizava a pertença de Colombo à Ordem de Avis.

Fontes:(https://www.outono.net/elentir/2015/03/14/bandera-capitana-de-cristobalcolon/); (https://pt.wikipedia.org/wiki/Coroa_de_Castela\#Os_Católicos:_União_com_ a_coroa_de_Aragão). 
N9 - Fala de um garimpeiro de Paramarimbo (Suriname), extraída de (THEJE, 2008, p. 77), em referência à passagem bíblica (Ageu 2:8-23): "Minha é a prata e meu é o ouro, diz o Senhor dos Exércitos". Ageu foi um profeta judeu, cujas profecias deram origem a um dos doze últimos livros proféticos do Velho Testamento protestante da Bíblia hebraica, que não inclui os livros deuterocanônicos das Bíblias católica e ortodoxa. Por ser chamado "O Profeta do Templo", Ageu provavelmente viveu na Babilônia, no tempo da reconstrução do templo de Jerusalém, isto é, por volta da primeira metade do século VI a.C.

(https://pt.wikipedia.org/wiki/Ageu); (https://pt.wikipedia.org/wiki/B\%C3\%ADblia_hebraica).

N10 - Passagem de (PONCE, 1983, p. 99-100), que esclarece as cruzadas do seguinte modo: "As cruzadas - apenas um episódio [...] da continuada luta entre o Ocidente e o Oriente - podem ser melhor compreendidas se atentarmos para as condições vigentes na Europa ocidental, no século XI. Predominava entre as populações cristãs incultas um verdadeiro espírito de ascetismo, uma verdadeira psicose religiosa que forçava os homens e as mulheres a buscar a salvação das suas almas por meio de uma estrita disciplina, de jejuns, de torturas, de mutilações e de arriscadas peregrinações. Destas, a visita aos lugares santos era a mais valiosa, capaz, por si só, de resgatar qualquer pecado cometido pelo peregrino, por mais hediondo que tivesse sido, e garantir à sua alma um lugar no céu. Se aliamos a isso o sistema de vida que imperava na aristocracia feudal daqueles tempos, composta por verdadeiros guerreiros profissionais, acostumados a ver em qualquer guerra um excelente meio de conquistar riquezas e fama, podemos compreender de que modo foi possível o movimento das cruzadas. Podemos compreender, então, que, quando os turcos se apoderaram da Palestina [...] e o Imperador de Bizâncio pediu socorro ao Papa para a defesa de seus territórios e Urbano II, no Concílio de Clermont, percebendo a oportunidade que se lhe oferecia de superar o Cisma Ortodoxo e restabelecer o prestígio papal, grandemente ameaçado, levantou a bandeira da guerra santa - acenando com a possibilidade de grandes pilhagens e com a salvação eterna das almas dos que atendessem ao seu apelo -, de toda a Europa ocorressem milhares de pessoas [...] para a luta contra o Islã” (PONCE, 1983, p. 99-100).

N11 - Tal imagem foi extraída do Livro de Lizuarte de Abreu (1558/1565) sobre Histórias das Armadas Portuguesas, em que são visíveis as cruzes da Ordem de Cristo nas velas dos navios. Pierpont Morgan Library. Manuscript. M.525. As bulas do Papa Nicolau V (1454) e do Papa Calisto III (1456) concederam à Ordem Militar de Cristo - instituída pelo Rei D. Dinis, em 1318, e confirmada pela Bula Ad ea ex quibus (1319), dada pelo Papa João XXII - o direito de exploração espiritual das comunidades ameríndias de todas as terras colonizadas através do empreendimento das grandes navegações marítimas. Essas bulas haviam decretado que as colônias europeias ultramarinas deveriam ser consideradas territórios nullius diocesis, isto é, sem dioceses, e também determinavam que a Igreja de Santa Maria do Olival - construída no século XII, na cidade portuguesa de Tomar -, e que já havia sido anteriormente o templo-sede da Ordem dos Templários (extinta em 1311 pelo Papa Clemente V), passaria a ser a sede diocesana comum dos novos territórios espirituais sem diocese. Quando o Infante D. Henrique foi nomeado administrador dos bens e dos recursos concedidos à 
Ordem, ele passou a utilizá-los para o financiamento do empreendimento das grandes navegações portuguesas. Foi assim que o emblema simbólico da ordem - a cruz rubra começou a aparecer estampado nas velas içadas das caravelas portuguesas em suas viagens exploratórias dos novos territórios colonizados, bem como nas bandeiras do reino de Portugal. Num dicionário de símbolos acessível em (https://www.dicionariodesimbolos.com.br/cruz-portugal/), lê-se o seguinte, a respeito da "cruz de Portugal": "A Cruz de Portugal é também chamada de Cruz da Ordem de Cristo. A Cruz tem os braços verticais e horizontais proporcionais, formando um quadrado. É vermelha e foi bastante utilizada durante as cruzadas. Ela simboliza a religiosidade, a vontade dos membros da Ordem de Cristo de espalhar o cristianismo em suas expedições. [...] Ela é usada em vários monumentos arquitetônicos, por exemplo, na Torre de Belém. O símbolo figurava também nas bandeiras dos navios, na época das expedições marítimas, para sinalizar para os povos pagãos que aquele navio era de povos cristãos. Deste modo, ela também ficou conhecida como Cruz dos Descobrimentos. Usá-la nas viagens marítimas era uma forma de honrar a Ordem de Cristo, instituição religiosa que contribuía financeiramente com as grandes navegações". Este mesmo dicionário distingue a cruz da Ordem de Cristo de duas outras que com ela poderiam ser confundidas, as denominadas Cruz de Malta e Cruz Templária: "A Cruz de Malta é também conhecida como Cruz de Amalfi ou Cruz de São João. Ela é o símbolo da Ordem dos Cavaleiros Hospitalários ou Ordem de Malta (daí o nome), uma ordem militar cristã. Baseada no símbolo das Cruzadas, a Cruz de Malta é representada por uma cruz de oito pontas. Suas pontas formam quatro braços simétricos que partem do centro e se juntam em suas bases. Seu significado advém de suas pontas, as quais representam os oito deveres dos cavaleiros: amor, arrependimento, fé, humildade, misericórdia, resistência, sinceridade e verdade. Essa cruz é um símbolo guerreiro dos cristãos, da coragem e das virtudes cristãs". Por sua vez, a Cruz Templária era "uma cruz vermelha utilizada pelos templários sobre as suas vestes brancas, simbolizando fé e proteção. Templários eram os membros de uma ordem militar religiosa de cavalaria medieval. Eram monges que tinham feito votos de pobreza e cujo espaço ocupado em Jerusalém teria sido parte do Templo de Salomão. Por esse motivo, essa ordem é conhecida pelo nome [...] Ordem do Templo ou simplesmente Ordem dos Templários. A Ordem foi criada para proteger os primeiros cristãos, na época das Cruzadas, expedições especialmente de caráter religioso que se formaram na Europa e que tinham como objetivo a conquista da Terra Santa. [...] O simbolo da Ordem dos Templários não era a cruz templária, mas sim um cavalo com dois cavaleiros no seu dorso. Por vezes é chamada de cru乏.pátea, [...] porque pertencia a uma categoria de cruzes que se caracterizam por serem côncavas, isto é, que tinham as pontas mais largas e que iam se alargando a partir do seu centro, como se fossem patas".

Fontes: (https://www.dicionariodesimbolos.com.br/cruz-templaria/). (file:///Users/antoniomiguel/Downloads/www.ordens.presidencia.pt.html); (http://www.ordens.presidencia.pt/archive/img/Livro_de_Lisuarte_de_Abreu_1_0_0.j pg);(https://pt.wikipedia.org/wiki/Patriarcado_de_Lisboa); (https://pt.wikipedia.org/wiki/Ordem_de_Cristo;(http://www.ordens.presidencia.pt/?i $\underline{\mathrm{dc}=120) ;}$ (https://www.dicionariodesimbolos.com.br/cruz-malta/).

N12 - Embora pareçam ser ainda mais antigas, cružes coptas semelhantes às duas últimas imagens do segmento N11 deste texto parecem ter sido usadas, no século I d.C., como emblemas 
por parte da comunidade - denominada copta pelos árabes do século VII d.C. - de egípcios convertidos ao cristianismo, para distingui-la da comunidade de egípcios convertidos ao islamismo, após esse século. Assim, embora uma versão semelhante a estas duas versões de cruzes coptas tenha sido adotada como símbolo da identidade religiosa dessa comunidade de cristãos egípcios constituída pelo apóstolo evangelista Marcos, por volta do ano 42 d.C., esta comunidade, ao longo do tempo, foi se ampliando e ganhando adeptos para além do continente africano, passando a constituir o que atualmente se denomina Igreja Ortodoxa Copta. Mas, a unidade que a matriz cristã copta aparentava sustentar vem fragmentando-se, cada vez mais, dando origem a uma diversidade de religiões cristãs ortodoxas, partindo-se da divisão inicial entre as Igrejas Católicas Coptas e as Igrejas Protestantes Coptas. Posteriormente, entre os séculos XI e XIII, partindo da Europa Ocidental em direção à Terra Santa, a Palestina - e, particularmente à cidade de Jerusalém -, orientados pelo propósito bélico de ocupá-la e mantê-la sob o domínio cristão, os cruzados hospitalários e os cruzados templários também adotaram distintas versões da cruz copta como emblemas de suas Ordens e das bandeiras que empunhavam em suas guerras santas travadas com diferentes propósitos, desde os econômicos, comerciais e territorialmente expansionistas, até os de cunho propriamente místico-peregrinatório visando a solicitações de graças divinas, a pagamentos de graças ou promessas conquistadas, ou ainda, à realização de práticas penitentes (orar, jejuar, fazer vigílias etc.) oferecidas a Deus como prova de arrependimento de seus pecados. Por outro lado, os palestinos viam essas guerras santas dos cristãos ocidentais como invasões francas, isto é, como invasões imperialistas de seus territórios por parte dos francos provenientes do Império Carolíngeo (800 d.C. - 888 d.C.). Tendo-se em vista estes dois modos opostamente distintos de se significar essas práticas bélico-cristãs ocidentais travadas na Idade Média e, posteriormente, denominadas cruzadas, é preciso destacar o fato de que eram os francos constituídos em Ordens deflagradoras de guerras santas que, vendo-se a si mesmos como soldados de Cristo, se autodenominavam cruzados, dado que se identificavam e se distinguiam entre si por diferentes versões emblemáticas da cruz copta bordadas em suas vestes e em suas bandeiras. Segundo Vilar (2012), “[...] embora carregue o nome ortodoxo, a Igreja Copta não está em comunhão com as Igrejas Católicas Ortodoxas ou Protestantes, sendo uma Igreja independente, apenas compartilhando a doutrina cristã entre si”. Quanto à versão de cruz copta que teria sido adotada como emblema por parte dessa comunidade primitiva de cristãos egípcios, mesmo que ela não tivesse sido uma criação original da própria Igreja Ortodoxa egípcia fundada pelo evangelista Marcos, mas tão somente uma apropriação adaptada por parte dessa Igreja de uma cruz emblemática de outra comunidade cristã primitiva, ela não poderia, é claro, ter funcionado como um emblema cristão antes da cruxificação do próprio Cristo, ainda que a forma geométrica cru₹ pudesse, anteriormente, ter participado de outros jogos simbólicos de linguagem entretecidos a outras formas de vida, como sugere o estudo realizado por Pereira (2002, p. 33): "Muito antes de ser conhecida no Ocidente, o aspecto estrutural da cruz já era usado por muitos povos. J. de Fraine afirma que desde os tempos pré-cristãos a cruz era conhecida, na Babilônia, como sinal, simbolo ou ornamento. Na fórmula da cruz gamada ou suástica ela já se encontra no Oriente antigo, mais tarde também entre os germânicos e na arte cristã. Na Ásia Menor encontra-se outra forma, a chamada cruz da roda do sol, no Egito a cruz de cabos, que se acha também entre os coptas. [...] Quanto à cruz de Jesus, Fraine diz que a mesma só pode ter sido a chamada cruz de santo Antônio, "crux commissa", sem a parte superior ou a "crux immisa" on "capitata", que podia ser de traves iguais (cruz grega) on desiguais (cruz latina). Alguns 
afirmam ser mais a segunda sugestão (crux immisa), conhecida como a Cruz da Paixão, pois na parte superior é que foi colocada a inscrição em hebraico, grego e latim: Jesus Naz̧areno, Rei dos Judeus" (PEREIRA, 2002, p. 33). Este estudo de Pereira também nos permite identificar jogos de linguagem dos quais o cristianismo primitivo - antes da queda do Império Romano do Ocidente e, portanto, antes da constituição do Império Bizantino teria feito participar o objeto material cruz e a palavra que a nomeia: "Paulo apóstolo, por ser de origem grega, explorou e consolidou o termo "staurós" para designar a cruz ou fazer referência à mesma. [...] J. Daniélou, no dicionário de teologia bíblica, afirma que dentre as interpretações simbólicas da cruz, deve-se frisar de modo especial a da epístola aos Efésios (2,16): pela cruz. duas partes contrárias são reconciliadas, o que equivale a dizer que não se trata de duas eras diversas on de duas orientações de fé diversas, mas também do céu e da terra. As quatro dimensões da cruz indicam a universalidade da salvação. Portanto, a morte de Cristo na cruz significou, para os cristãos, que todos são chamados à salvação, independentemente de raça, cor, classe social ou religião, basta seguir os preceitos evangélicos que é a prática da justiça. [...] Referentes aos três primeiros séculos da era cristã, B. M. Aherns pontua-nos que os escritos destes períodos desenvolvem o significado da cruz como instrumento da obra salvífica divina, e para isso recorrem principalmente a uma interpretação tipológica alegórica do Antigo Testamento, à imitação do próprio Novo Testamento. Assim, comparam a arca de Noé, com a lenha do sacrifício que Isaac levou ao monte Moriá, com a escada de Jacó, com a vara de Moisés e com a serpente de bronze. Estes motivos foram amplamente desenvolvidos na catequese da época e passaram a ser parte da liturgia do batismo e da Eucaristia. [...] também neste periodo primitivo, uns poucos escritores, como Santo Inácio de Antioquia e São Policarpo, lembram os sofrimentos de Cristo para reforçar seu convite a serem fiéis a Deus, à imitação Mestre que, por sua vez, foi submetido à perseguição. Esta referência tinha a finalidade de lembrar o compromisso assumido e não perder de vista a essência do ser cristão, [...] a conversão do imperador Constantino e o fato de ter sido encontrada a Cruz de Cristo deram impulso notável às manifestações públicas de veneração da Cru₹: Com a adoção do cristianismo como religião do império, a cruz surgiu como simbolo oficial. Transformou-se em estimulo para as pessoas se dedicarem com generosidade e se sacrificarem neste mundo, numa garantia de triunfo na vida futura (PEREIRA, 2002, p. 34-37). Por sua vez, Vilar apresenta um argumento iconográfico bastante convincente em favor da conjectura de que as diferentes versões da cruz copta usadas como emblema pela Igreja Ortodoxa copta teriam sido meras adaptações gráficas ou gráfico-artísticas do hieróglifo egípcio ankh, que é a primeira imagem à esquerda das três que reproduzimos neste parágrafo de nosso texto: "Quanto ao [hieróglifo] ankh (fala-se anak ou anrr), este passou a ser chamado pelos coptas de cruz ansata ou cruz copta. O ankh de fato lembra uma cruz, e simbolizava, na escrita hieroglífica egípcia, a vida após a morte, ressurreição, vida, imortalidade da alma etc. Logo, se a cruz cristã personificava a morte de Cristo, seu flagelo para salvar a humanidade, a esperança de salvação nele etc., foi fácil adaptar esse símbolo à nova religião" (VILAR, 2012). Como se nota, o que a própria a história do cristianismo evidencia é a multiplicidade de significados de que a cruz se revestiu ao longo dessa história, de modo que ela poderia até mesmo ser contada tomando-se como eixo orientador os inúmeros jogos de linguagem dos quais a cruz participou e continua participando como objeto simbólico significativo. De fato, de acordo com matéria publicada no site abaixo referido acerca do significado da cruz para comunidades cristãs no mundo muçulmano, lê-se: "No Ocidente, mulheres usam, frequentemente, um crucifixo simplesmente como uma joia moderna, mas, para os cristãos no Oriente Médio, que resistiram a catorze séculos de opressão islâmica, a cruz 
tem uma simbologia profunda de identificação com sua fé, sua igreja e sua comunidade. Enquanto que, para os muçulmanos, a cruz é um símbolo odiado de uma religião "falsa" que foi alvo dos exércitos muçulmanos, religião esta que, mais tarde, respondeu militarmente, sob esse símbolo, através das Cruzadas, para os cristãos de igrejas antigas no Oriente Médio, que já sofreram muito, a cruz significa a sua identidade como uma comunidade cristã. Para esses cristãos, a cruz simboliza os longos séculos de perseguição e martírio, e a lealdade à sua igreja perante a perseguição muçulmana. O ódio muçulmano pela cruz é evidente na hadith (tradições) que profetiza a fé muçulmana de que, no fim dos tempos, Jesus irá reaparecer como um muçulmano e quebrará todas as cruzes. Na história, por exemplo, o califa al-Mansur (754-775) proibiu que a cruz fosse exibida em público e destruiu algumas cruzes que ficavam no topo de algumas igrejas. O califa al-Hakim (9961021) obrigou cristãos a usarem uma cruz de cinco pontas em seus pescoços como um sinal de humilhação. A proibição de exibir a cruz em público continua em vigor, atualmente, na Arábia Saudita”. Fonte:

(https://www.portasabertas.org.br/noticias/cristaos-perseguidos/200611 noticia3119). Nos primeiros séculos da era cristã, o Egito pertencia ao Império Romano do Oriente, isto é, ao Império Bizantino. Após os persistentes conflitos armados travados entre este Império e os califados árabes, entre os séculos VII e XII, o Império Bizantino sofreu uma perda territorial considerável, e uma parte desse território foi ocupada pelos árabes que professavam a fé islâmica e denominavam os povos bizantinos, dentre eles, os egípcios, de rumes, isto é, romanos. Assim, a partir desta ocupação, o cristianismo copta praticado no Egito tendeu a radicalizar a sua fé, em razão da forte opressão religiosa a que ficou submetido. Essa perseguição religiosa aos cristãos egípcios coptas persiste até os dias de hoje, como atesta esta outra passagem da matéria acima referida publicada no site Portas abertas: servindo cristãos perseguidos: "Cristãos coptas no Egito veem sua cruz como a maior vitória de sua igreja e como um símbolo de seu longo martírio. Eles tatuam a cruz no pulso direito, como forma de orgulho e oposição, como uma marca indestrutível de sua identificação com sua comunidade e igreja, apesar de saberem que essa marca visível pode trazer desprezo e discriminação na sociedade em que vivem, onde a maioria é muçulmana: Muitos de nós temos essas cruzes no pulso. Temos certeza que uma perseguição grave atingirá o Egito e não temos certeza se poderemos enfrentá-la. Escolhemos ter marcas indestrutiveis como seguidores de Cristo para que nunca possamos renegá-lo, nem mesmo em nossos momentos de fraqueza. Às vezes, os ataques físicos a cristãos no Egito são focados na tatuagem da cruz em seus pulsos. Por exemplo, em abril de 2005, uma garota copta de 17 anos foi sequestrada por um grupo extremista islâmico (o sequestro e a conversão forçada de jovens coptas é um problema grave no Egito). Durante 23 horas, ela foi drogada, estuprada e tentaram remover a tatuagem dela com uma tesoura. Enquanto que para os cristãos protestantes o símbolo físico da cruz não é uma questão essencial de fé, para muitos cristãos no mundo oriental, isso ainda continua sendo um símbolo forte da morte e ressurreição de Cristo, a alma de sua fé. Ao usá-la, eles se identificam com Cristo e com sua humilhação e sofrimento". Fontes:

(http://seguindopassoshistoria.blogspot.com/2012/05/);

(https://st-takla.org/Gallery/Christian-Symbols-and-Church-Tools/Cross/Coptic-

Cross-02.html);

(https://st-takla.org/Gallery/Kids/Coloring/Christian/Cross/Coptic-Cross-11.html); (https://st-takla.org/Gallery/search.html?q=coptic+icon); 
(https://pt.wikipedia.org/wiki/Coptas);

(https://pt.wikipedia.org/wiki/Cruzada);

(http://seguindopassoshistoria.blogspot.com/2012/05/);

(https://pt.wikipedia.org/wiki/Igreja_Ortodoxa_Copta);

(https://pt.wikipedia.org/wiki/Cruz_da_Ordem_de_Cristo);

(https://pt.wikipedia.org/wiki/Guerras_bizantino-árabes).

N13 - Afresco intitulado Batismo de Cristo (1498/1500) dos pintores renascentistas italianos Pietro Perugino (c. 1448 - 1523) e Bernardino di Betti (1454-1513), chamado Pinturicchio, que faz parte de uma obra maior de ornamentação da Capela Sistina, em Roma/Itália, cujo objetivo era fazer um paralelo entre a vida do profeta Moisés, descrita no Antigo Testamento, e a de Jesus Cristo, descrita no Novo Testamento. Dado que, para a comunidade católico-ortodoxa de Shtip, o dia 19 de janeiro em que se realiza a prática do pega-cruz é um feriado religioso nacional em que se comemora a Epifania de Jesus Cristo, isto é, simultaneamente o batismo de Cristo e as bodas de Caná - a aldeia árabe de Kafr Kanna na Baixa Galiléia -, é razoável supor que a prática do pega-cruz poderia estar tradicionalmente fazendo referência a essas duas passagens da vida de Cristo, quais sejam, a do seu batismo, nas águas do Rio Jordão, pelo profeta João Batista, e à sua participação, juntamente com os seus discípulos, de um casamento na cidade de Caná, em que ele realiza o seu primeiro milagre, qual seja, o da transformação da água em vinho, após o vinho da festa ter-se acabado. Ambos os acontecimentos estão relacionados com a água, o que, de certo modo, explica que a prática do pega-cruz seja uma prova que se realize nas águas de um rio, no caso o rio Otinja, um afluente de um outro rio - o Bregalnica - que também cruza a cidade de Shtip e que, na língua dos dois povos antigos - os derrones e os laeaeanos que habitaram, por volta dos séculos V e IV a. C., a região da bacia hídrica que incluía esta cidade, era denominado rio Astibo. Mesmo após terem sido submetidos, no ano de 480 a. C., pelos iranianos (denominados persas pelos europeus, por influência dos historiadores gregos antigos) liderados pelo rei Xerxes I, esses povos peônicos - que viveram na região atualmente denominada Macedônia do Norte, ex-Iugoslávia - conservaram um inquebrável poder de organização interna, mesmo após sucessivas invasões do seu território: primeiro pelos romanos, a partir do século II a.C.; depois, da Antiguidade tardia até o final da Idade Média, pelos bizantinos, isto é, pela parte oriental do Império Romano que falava o idioma grego e tinha a sede na cidade de Constantinopla, a antiga Bizâncio e a atual Istambul, na Turquia; após séculos de disputa entre os impérios bizantino, búlgaro e sérvio, a região caiu sob domínio dos turcos otomanos do século XIV até o início do século XX, quando, após as guerras dos Balcãs de 1912 e 1913, o território moderno da Macedônia do Norte ficou sob domínio sérvio e, após a Primeira Guerra Mundial, foi incorporado ao Reino da Iugoslávia. Já a promessa de prosperidade e felicidade que orienta a competição pela cruz na prática do pega-cruz poderia estar associada à prática cerimonial do casamento na tradição judaicocristã. Mas, tal promessa, poderia também estar associada à prática cerimonial do batismo, nessa mesma tradição, não tanto por esta última prática estar associada, regressivamente, à promessa da "lavagem da alma" maculada pelo pecado original em razão da transgressão, por parte de Adão e Eva, da ordem divina de não se comer o fruto da árvore do conhecimento, mas, sobretudo, por estar teleologicamente associada à promessa de perdão dos pecados, no dia do Juízo Final e, portanto, ao prêmio ou recompensa futura de uma vida eterna feliz, 
no reino paradisíaco de Deus, reino que se opõe ao fogo eterno do inferno, ao qual estariam condenados todos aqueles que não resistissem, tal como Adão e Eva, às tentações do discurso das serpentes. É por essa razão que o batismo de Cristo foi realizado nas águas de um rio, por um profeta, cuja profecia prediz simultaneamente a vinda do Messias redentor dos pecados do mundo e o prêmio ou a recompensa teleológica de uma vida eterna feliz para todos os que praticarem, na vida terrena, o seu discurso de amor ao próximo e de perdão.

Fontes: (https://www.bhfieldschool.org/countries/macedonia/shtip); (https://pt.wikipedia.org/wiki/Bodas_de_Caná);(https://pt.wikipedia.org/wiki/Štip); (https://en.wikipedia.org/wiki/Otinja);(https://en.wikipedia.org/wiki/Bregalnica); (https://pt.wikipedia.org/wiki/Macedónia_do_Norte). (https://virusdaarte.net/perugino-batismo-de-cristo/).

N14 - Na Nota 13, estabelecemos uma possível conexão semântica entre a prática do pegacruz e dois episódios bíblicos relativos à vida de Jesus Cristo: o seu batismo pelo profeta João Batista, nas águas do Rio Jordão, e à sua participação, juntamente com os seus discípulos, em um casamento na cidade de Caná - a aldeia árabe de Kafr Kanna, na Baixa Galiléia -, no qual Jesus, a pedido de sua mãe, Maria, teria feito o seu primeiro milagre, qual seja, o de transformar água em vinho. Nesse sentido, a prática do pega-cruz poderia ser vista como uma prática estritamente religiosa, dado que estaria simbolizando, isto é, remetendo a ou citando esses dois episódios bíblicos constituídos e narrados no interior da forma de vida de religiões judaico-cristãs. Pensamos ser legítima tal conexão semântica, uma vez que para a comunidade católico-ortodoxa da cidade macedônia de Shtip, o dia 19 de janeiro, em que se realiza a prática do pega-cruz encenada no filme de Mitevska (2019), é um feriado religioso nacional em que se comemora a Epifania de Jesus Cristo, isto é, simultaneamente o batismo de Cristo e as bodas de Caná. É interessante observar, porém, na imagem superior do segmento textual a que esta nota se refere - a fotografia por Antonio Miguel de uma cena do filme de Mitevska (2019) -, que a cruz que o pároco ortodoxo Kosta leva às mãos na procissão que a conduz ao rio no qual ela deverá ser lançada para se realizar a prova anual do pega-cruz, é envolta por ramos de flores e de cereais. Podemos, então, perguntar: que significados poderiam ser legitimamente atribuídos particularmente a esta cruz de flores e cereais? O ato de se jogar a cruz na correnteza do rio Otinja - e apenas homens se porem à sua busca, crentes na promessa de que aquele que primeiro a pegar terá um ano de prosperidade, abundância, fartura e felicidade - cita ou remete inúmeros jogos artísticovisuais de linguagem dos quais artistas de diferentes épocas fizeram uma das versões da deusa romana da Fortuna participar, qual seja, aquela em que esta deusa aparece empunhando, em uma das mãos, uma cornucópia, isto é, um vaso em forma de chifre repleto de frutas e flores e, na outra mão, ramos de cereais, quase sempre ramos dourados de trigo, simbolizando a fertilidade, a riqueza e a abundância, tanto na vida pessoal quanto nas formas de vida do comércio e da agricultura. Por sua vez, esta versão da deusa romana da Fortuna cita ou remete à deusa grega Ops, uma vez que os vários jogos artístico-visuais de linguagem - escultóricos ou plásticos - dos quais esta deusa participa remetem, direta ou metaforicamente, ao campo de atividade da agricultura. Esses jogos geralmente a encenam como uma mulher de rosto sereno, frequentemente com os olhos fechados, com cabelos longos e esvoaçantes, em um cenário campestre repleto de flores e vegetação que simboliza a oportunidade, a abundância, a fartura, a prosperidade e a riqueza resultantes das colheitas 
agrícolas exitosas. Às vezes, a deusa Ops é também artisticamente retratada amamentando um bebê ou contracenando com crianças, o que simboliza a fertilidade e a maternidade humanas como uma extensão metafórica do solo fértil e bem preparado para a semeadura. Foi deste último modo que o pintor francês Noël Coypel (1628 -1707) retratou a deusa Ops em sua pintura a óleo sobre tela intitulada Abundância (1700), na imagem inferior que apresentamos no segmento de texto que remete a esta nota, em que é a criança sentada no chão - e não Ops - que abraça um feixe de ramos dourados de trigo. O culto à deusa Ops parece ter sido instituído no oitavo século a.C. pelo rei sabino Tito Tacio e, mais tarde, Ops e outras versões romanas dessa deusa grega ou de sua filha Ceres - posteriormente cultuada entre os gregos antigos como a deusa da agricultura, do cultivo de grãos, da maternidade e da fertilidade -, bem como as deusas romanas Deméter e Fortuna com cornucópia, foram veneradas pelos cristãos como santas padroeiras da prosperidade, da riqueza e da abundância de pessoas e de comunidades. Assim, os ramos de flores e cereais amarrados à cruz lançada ao rio pelo pároco Kosta mostra-se em consonância simbólicosignificativa com a promessa de prosperidade e abundância que constitui o propósito da prática lúdico-religiosa do pega-cruz.

Fontes: (https://en.gallerix.ru/album/Versailles/pic/glrx-1600611044);

(https://mitologia.guru/dioses-mitologicos/ops/);

(https://pt.wikipedia.org/wiki/Noël_Coypel);

(https://fr.wikipedia.org/wiki/Fichier:Noël_Coypel___L\%27Abondance_(1700).jpg).

N15 - (PONCE, 1983, p. 112). Fonte: (https://www.apuntesdeviajes.com/2011/03/enbusca-de-el-dorado.html).

N16 - (ALBERT, 1995, p. 20). Fala de Davi, índio Yanomani sobre a extração de ouro por garimpeiros em suas terras.

N17 - (RAMOS, 2012, p. 8). Esta fala sobre ouro e ética na extração do outro entre os indígenas Ye'kuana - os vizinhos caribenhos dos Sanumá, que vivem numa região do município de Auaris, situado ao norte do Estado de Roraima - é da indígena Karenina Andrade.

N18 - (SLATER, 1994, p.79). Fala de um garimpeiro sobre mitologia da extração do ouro.

N19 - Juan Rodríguez Freyle, na sua crônica intitulada 'El Carnero' (1636-1638, p. 13-14), narra como o cacique-sacerdote dos muiscas era ritualmente transformado em polvo de ouro no festival religioso de Guatavita (Colômbia), perto do local onde hoje está Bogotá. Esta fala é registrada num conjunto de publicações do Museu do Ouro da Colômbia. Fonte:

(https://m.facebook.com/MuseoDelOroBanRep/photos/a.497665802470/1015689354 $7452471 /$ ?type $=3 \&$ source $=57 \&$ \& $t$ _ $=E H-R)$.

N20 - (ALBERT, 1995, p. 11). Fala de Davi Kopenawa, xamã cuja trajetória interétnica, associada ao universo das ONGs indigenistas e ambientalistas, tomou forma durante os 
anos 1980, na luta pela demarcação das terras Yanomami invadidas por uma feroz corrida do ouro.

N21 - (ALBERT, 1995, p. 13). Fala de Davi Kopenawa sobre a extração de ouro em suas terras realizada por garimpeiros.

N22 - Passagem extraída do livro de Juan Friede, intitulado Los Chibchas bajo la dominación (1974), acerca de O Dourado na Colômbia do conquistador espanhol Sebastián de Belalcázar (1480 - 1551). O nome Belalcázar é formado a partir das palavras árabes ben e alcázar, equivalentes a "filho do castelo" ou "filho da fortaleza". Fontes: (https://www.eldoradocolombia.com/belalcazar.html);

(https://pt.wikipedia.org/wiki/Sebastián_de_Belalcázar).

N23 - (CASA FIAT DE CULTURA, 2008, p. 96). Esclarecimentos sobre "El Dorado" e como o mito evoluiu para uma suposta terra dona de riquezas além de toda a expectativa, o que despertou o imaginário de sucessivas levas de rapazes aventureiros que se puseram à sua busca.

N24 - Fonte: (https://pt.m.wikipedia.org/wiki/Eldorado).

N25 - Com licença poética, fizemos a tradução do poema Eldorado do escritor e poeta norteamericano Edgar Allan Poe (1809-1849). O poema, escrito originalmente em inglês, é de domínio público e pode ser acessado no site: (pt.m.wikipedia.org/wiki/Eldorado); (http://www.dominiopublico.gov.br/download/texto/ln000029.pdf).

N26 - Região denominada Montanhas Douradas do Altai, no sul da Rússia, hoje considerada Patrimônio Mundial pela UNESCO. Na Idade do Bronze, ela foi habitada por muitos povos nômades, dentre eles, o povo Pazyryk, que habitou essa região entre os séculos VI e III a. C. Era uma prática dessa comunidade construir túmulos com toros de lariço - um tipo de pinheiro siberiano - cobertos por pedras, muito parecidos com os túmulos dos citas - um povo de pastores nômades equestres que habitou, no mesmo período, uma região denominada Cítia que, atualmente, constitui parte do território da Ucrânia e parte do território da Rússia. Escavações feitas em sítios arqueológicos nessa região encontraram um conjunto de artefatos em ouro deixados pelos citas no interior de seus túmulos. Foi o historiador grego Heródoto, em sua obra Histórias (século V a.C.), que chamava Montanhas Douradas à cordilheira do Altai, conjunto de montanhas que ocupa, atualmente, os territórios da Rússia, China, Mongólia e Cazaquistão. A forma de vida constituída pelos Pazyryk tinha o cavalo como o seu eixo estruturante, razão pela qual este animal participava de seus rituais religiosos, de seus cultos sacrificiais e de seus rituais fúnebres. Fontes:

(https://pt.wikipedia.org/wiki/Pazyryk);

(https://pt.wikipedia.org/wiki/Religião_cita);

(https://pt.wikipedia.org/wiki/Montanhas_Douradas_do_Altai);

(https://pt.wikipedia.org/wiki/Reserva_Natural_de_Katun). 
N27 - Um imaginário indígena habitante de uma lendária cidade denominada Manoa - ou Eldorado - tendo o corpo coberto de ouro em pó. Gravura fac-símile do oitavo volume das Grand Voyages (1599) do ourives, ilustrador e editor holandês Theodore de Bry (1528 - 1598). Coleção particular, Rio de Janeiro, Brasil. Embora De Bry nunca tivesse viajado às Américas, ele criou um grande número de gravuras para seus livros, em grande parte baseadas em observações e relatos de exploradores que participaram de expedições para o novo continente.

Fontes: (https://fantasia.fandom.com/pt/wiki/Eldorado); (https://www.wikiwand.com/en/Theodor_de_Bry).

N28 - Esta imagem retrata o cacique de Manoa tendo o corpo coberto de ouro em pó. Gravura do oitavo volume das "Grand Voyages" de Theodore de Bry (1599), fac-símile. Coleção particular, Rio de Janeiro, Brasil. (Fonte: https://fantasia.fandom.com/pt/wiki/Eldorado). É importante notar, que “o deslocamento do Eldorado para as fronteiras entre o Brasil, a Venezuela e as Guianas terminaria sendo consagrado pela cartografia seiscentista, fato bem exemplificado pela "Guiana sive Amazonum Regio", mapa de autoria dos cartógrafos holandeses Henricus Hondius (1597 - 1651) e Joannes Janssonius (1588 - 1664), datado do segundo quartel do século XVII (ca. 1635). A exemplo de vários de seus contemporâneos e sucessores, Hondius não hesita em traçar os limites de um verdadeiro mar interior - o Lago Parima e situar a esplêndida Manoa ou Eldorado - retratada como uma cidade de torres altaneiras em sua margem ocidental. Em 1682, uma disposição semelhante seria adotada por A. De Winter na "Zuider America", uma versão da carta da América do Sul elaborada, anos antes, por Nicolas Sanson. Destinado a perdurar em mapas pelo menos até o final século XVIII, o fabuloso lago Parima teria uma vida mais curta do que o mito do Eldorado. Em 1720, a administração da Guiana Francesa daria pleno apoio financeiro aos aventureiros que partiam em busca da mítica cidade, alguns dos quais apoiados pelo próprio governador Claude Guillouet d'Orvilliers". (CASA DA CULTURA FIAT, 2008, p. 96). Outras fontes: (https://pt.wikipedia.org/wiki/Johannes_Janssonius);

(https://commons.wikimedia.org/wiki/File:Guiana_sive_Amazonum_regio_(864233584 7).jpg); (https://en.wikipedia.org/wiki/Henricus_Hondius_II).

N29 - Informação acerca da lendária cidade de Manao baseada em Guzmán (1997, p. 6869, p. 44). Ele também destaca que nos relatos coloniais sobre os indígenas manaós, é frequente associá-los à descoberta ou à comercialização de ouro nas adjacências dos rios Solimões, Negro, Essequibo, Branco e Orinoco, entre os anos 1600 e 1700.

N30 - Passagem de (GUZMÁN, 1997, p. 69) que esclarece como Manoa, comparada às outras cidades do Império espanhol, as superava em amplidão, em riquezas e em localização.

N31 - Mapa de 1599 produzido pelo explorador e poeta britânico Walter Raleigh (1552 - 1618) e pelo ourives, gravurista e editor holandês Theodor de Bry (1528 - 1598), descrevendo o Lago Parima como "um mar salgado de 320 km (320 km) com ilhas". Segundo Raleigh, tal lago "é chamado Parima pelos canibais, enquanto os Yaos o chamam 
de Foponowini". O mapa mostra também os movimentos de territorialização que se processaram tendo como propósito a busca de eldorado. Tais movimentos ocorreram entre a Colômbia - através de expedições pelas regiões do rio Orinoco -, Venezuela - através de expedição organizada por Diego de Ordaz, no início do século XVI -, Guiana, Brasil e Peru. Tais expedições foram organizadas pelas coroas espanhola, inglesa e portuguesa. Segundo Guzmán (1997, p. 29), os manaós foram associados à cidade de Manoa, localizada às margens do Lago Dourado, na qual, segundo a lenda, morou o último Inca, fugitivo da invasão de Cuzco por Pizarro. Além da semelhança fisionômica dos Incas com os habitantes imaginários da lendária cidade dourada, havia também um comentário feito pelo Padre Samuel Fritz em seu relato de viagem, de que alguns manaós tinham sido encontrados nas proximidades do rio Orinoco, junto aos índios Yurimagua, comercializando urucu, raízes de mandioca, redes de cachibanco, armas e ouro. Tais relatos foram produzidos num contexto de disputas coloniais intensas que ocorriam no Velho Mundo, naquele momento histórico, e que atravessavam o Oceano Atlântico e chegavam na região amazônica, configurando conflitos entre sociedades europeias nas selvas das guianas e no vale do rio Amazonas. Era fundamental obter acesso ao território médio do Rio Negro, porque isso possibilitava a abertura de um caminho para os rios Solimões, Branco e Orinoco, região em que, antes de 1960, já havia comercialização de ouro, armas e escravos entre os manaós e os holandeses.

Fontes:(https://www.wikiwand.com/en/Theodor_de_Bry); (https://pt.wikipedia.org/wiki/Walter_Raleigh).

N32 - Fala do narrador do filme de Caldeira (1977) que se inicia em [00h:15min:15s]. Os manaós adoravam o rei Manari, o deus da floresta. Ajuricaba, um indígena da nação manaós se refugiou na floresta após a sua comunidade aceitar, sem lutar e sem se opor, os presentes e trocas propostas pelos brancos portugueses. Em seu tempo de refúgio, Ajuricaba, em um ritual xamã, recebeu o espírito de seus ancestrais, seu avô, para expulsar os invasores e defender a floresta.

N33 - Fala do narrador do filme de Caldeira (1977), que se inicia em [00h:45min:10s], na qual Belchior é parabenizado pelo império protuguês pelo seu trabalho de conquista dos índios sem perder muitas vidas.

N34 - O texto em versos deste segmento é a famosa passagem do Livro 6 da Eneida do poeta romano Virgílio (70 a.C. - 19 a.C.), que narra a saga do herói Enéias. Nesta passagem, o poeta faz referência ao ramo dourado como passaporte para a entrada no mundo inferior. Foi nesta passagem da Eneida que o antropólogo escocês James George Frazer (1854-1941) alega ter-se inspirado para a produção de sua obra monumental em 13 volumes (FRAZER, 1982, p. 39) intitulada O ramo de ouro. Na tradução brasileira de O ramo de ouro, o tradutor Waltensir Dutra - esclarece do seguinte modo o propósito que teria orientado Frazer em sua investigação historiográfico-antropológica, bem como o método que o teria orientado nessa investigação: "Em Nemi, perto de Roma, havia um santuário onde, até os tempos imperiais, Diana, deusa dos bosques e dos animais e promotora da fecundidade, era cultuada com o seu consorte masculino Vírbio. A regra do templo era a de que qualquer homem podia ser o seu sacerdote e tomar o titulo de rei do bosque, desde que, primeiro, arrancasse um ramo - o 
ramo de ouro — de uma certa árvore sagrada do bosque em que ficava o templo e, em seguida, matasse o sacerdote. Era essa a modalidade regular de sucessão no sacerdócio. O objetivo de $O$ ramo de ouro é responder a duas perguntas: por que o sacerdote tinha de matar o seu predecessor, e por que devia, primeiro, colher o ramo dourado?". Em seguida, o tradutor esclarece o método que teria orientado Frazer em sua investigação: "Como não há uma resposta simples para nenhuma das duas perguntas, Frazer recolhe e compara analogias com esse costume [diríamos nós, com essa prática cultural] de Nemi. Mostrando a existência de regras semelhantes em todo o mundo e através de toda a história, ele espera chegar à compreensão da maneira pela qual a mente primitiva funciona para, a partir dessa compreensão, lançar luz sobre a regra do santuário de Nemi. Ao recolher analogias, Frazer não busca paralelos totais, mas divide a tradição de Nemi em suas partes componentes, examinando-as uma a uma. $\mathrm{Na}$ verdade, cada uma de suas descobertas estabelecidas como evidências pode ser usada em relação a mais de um aspecto da questão" (FRAZER, 1982, p. 44).

Fontes: (https://www.wikiwand.com/pt/Eneida); (https://www.meisterdrucke.pt/impressoes-artisticas-sofisticadas/Joseph-MallordWilliam-Turner/22871/Enéias-e-o-Sybil-Cumaean.html).

N35 - A pintura a óleo sobre tela intitulada Enéias e a Sibila de Cumas (1815) é de autoria do pintor romântico inglês Joseph Mallord William Turner (1775-1851). Sob um belo cenário mediterrâneo, Enéias, com vestes vermelhas e de costas para o observador, está perguntando à Sibila de Cumas - a sacerdotisa do oráculo dessa colônia grega fundada em 750 a.C., hoje localizada na Itália -, de vestes brancas, sobre como entrar no mundo inferior. Em primeiro plano, pode-se ver lajes de pedra que, obviamente, marcam a entrada para o submundo.

N36 - Versos do ensaísta e historiador britânico Thomas Babington Macaulay (1800-1859) eleitos por Frazer como epígrafe de sua obra em 13 volumes $O$ ramo dourado (FRAZER, 1982, p. 48). Os versos são originalmente os seguintes: "The still glassy lake that sleeps / Beneath Aricia's trees / Those trees in whose dim shadow / The ghastly priest does reign / The priest who slew the slayer / And shall himself be slain". São estes versos que nos levam a estabelecer uma conexão entre a obra de Frazer e a de Macaulay e a ver, em ambas, a orientação whig no modo de se conceber e de se fazer história. O fato de Frazer ter eleito tais versos de Macaulay não nos parece casual. Na realidade, a citação de tais versos como epígrafe de abertura de sua obra constitui uma espécie de chave analógico-metonímica de acesso ao dogma metodológico que orienta toda historiografia whig, da qual a obra The History of England de Macaulay constitui um exemplo paradigmático. A história da Inglaterra de Macaulay, tal como a historiografia antropológica de Frazer, também foi escrita em estilo literário e foi muito admirada em seu tempo, mesmo após, no século XX, as historiografias orientadas por perspectivas positivistas terem sido alvo de severas críticas no mundo acadêmico. $\mathrm{O}$ que estamos aqui denominando historiografia whig é uma abordagem de um problema na história - geralmente, tal problema é o da constituição de um estado nacional na história que apresenta o passado como uma progressão inevitável em direção a um futuro luminoso, democrático, feliz e não obscurantista. Assim, historiografias whig são geralmente historiografias iluministas, cientificistas, nacionalistas, políticas, progressivistas, 
evolutivas e teleológicas que, na maior parte das vezes, identificam o estado democrático por vir como um estado democrático constitucional liberal ou monárquico-constitucional. Mas há exceções a esse respeito, uma delas sendo a própria perspectiva historiográfica defendida pelo materialismo histórico-dialético, em que o estado democrático por vir é visto como um estado comunista que resolveu o problema das desigualdades sociais e no qual, portanto, não mais impera a luta de classes. No caso da História da Inglaterra de Macaulay, a perspectiva whig o leva a ver a Grã-Bretanha como o limite teleológico modelar de nação civilizada de modo que, para ele, o campo geopolítico global das nações é dividido entre, por um lado, nações mais ou menos civilizadas, dependendo do quão próximas elas estejam do modelo britânico de organização social e política e, por outro lado, em nações vistas como "bárbaras" ou "primitivas". Por sua vez, as historiografias whig das ciências tendem a enfatizar ou a tornar exclusivas abordagens progressivistas e evolutivas de uma determinada ciência na história em que os conflitos e as experiências fracassadas são intencionalmente ignoradas, o que as tornam abordagens racionalizadas, destiladas exclusivamente das teorias científicas bem sucedidas acerca de determinados fenômenos ou problemas.

Fonte: (https://en.wikipedia.org/wiki/Thomas_Babington_Macaulay).

N37 - Tradução livre de um trecho do texto de Candace Slater (1994, p. 725), antropóloga norte-americana que transcreveu a fala de um garimpeiro da região de Paramarimbo (Suriname), na década de 1990, em que o poder de aparecimento do ouro é visto como uma manifestação das forças do acaso, como possibilidade do impossível. A autora registrou contos e mitologias dos garimpeiros que se instalaram nessa região para a extração manual de ouro. Os garimpeiros eram oriundos, predominantemente, do Estado do Pará e do Maranhão.

N38 - Fala de um garimpeiro de Paramarimbo citada em Slater (1994, p.726), em que o ouro parece mover-se pela imprevisibilidade do acaso. Nessa fala, a palavra barranco, usada pelo garimpeiro, significa um território físico onde os garimpeiros instauram ferramentas, dormitórios e equipamentos para a extração de ouro.

N39 - Verso de Menandro extraído de Fragments (PONCE, 1983, p. 112). Menandro (342 a.C. - 291 a.C.) foi um escritor ateniense de peças teatrais, sobretudo, comédias cujas personagens são inspiradas em pessoas comuns - cozinheiros, escravos, médicos, filósofos, adivinhos e militares, uma vez que, em sua época, as autoridades políticas passaram a censurar e a estabelecer forte controle sobre a atividade de escritores, poetas e dramaturgos, proibindo a sátira a instituições e a homens públicos.

N40 - A jornalista venezuelana Paula Ramón publicou na revista Piauí na edição 159 de dezembro de 2019 o artigo intitulado Eldorado trágico: os caminhos violentos do garimpo no país de Maduro (RAMÓN, 2019). Nele, ela trata dos problemas provocados pelo garimpo em territórios do país, bem como de uma série de planos para organizar e controlar a mineração no país anunciados pelo presidente Hugo Chávez. 
N41 - Passagem extraída da publicação (FUNDACIÓN GAIA AMAZONAS, 2000, p. 237) relativa à salvaguarda do patrimônio cultural imaterial do noroeste amazônico. Tal publicação é uma iniciativa binacional entre Colômbia e Brasil, na qual se procura desenvolver uma cartografia dos locais sagrados indígenas.

N42 - Trata-se da empresa mineradora canadense COSIGO em sua furiosa luta imperialista pela exploração do parque natural Yaigoje Apaporis. Ela possui um título que autoriza a mineração nesse parque e veio seduzida pelo que na região se conhece como o "cinturão de ouro de Taraira, um dos maiores e inexplorados distritos de ouro do mundo", como afirmam em sua página na web abaixo referenciada. A empresa já opera no município de Taraira e na Amazônia brasileira. A COSIGO assegura que pode extrair o precioso minério atuando dentro dos padrões ambientais.

Fonte: (https://especiales.semana.com/especiales/parque-apaporis-mina/).

N43 - Fala do indígena colombiano Leonardo Rodríguez Makuna líder dos povos indígenas que habitam as margens do rio Apaporis. O rio Apaporis é um rio que corre pela região amazônica colombiana, um afluente do rio Caquetá, denominado Japurá, no Brasil. Em seus últimos 50 quilômetros, ele forma uma fronteira natural com o estado brasileiro do Amazonas. Os principais povos indígenas que habitam as margens do rio Apaporis são: Desana, Tukano, Tuyuka, Cabiyarí e Yuhupde. Fontes:

(FUNDACIÓN GAIA AMAZONAS, 2014 p. 51). (https://www.semana.com/nacion/articulo/el-avatar-colombiano/240100-3). (https://es.wikipedia.org/wiki/R\%C3\%ADo_Apaporis).

N44 - Fala de Arturo Macuna, habitante do rio Apaporis. (FUNDACIÓN GAIA AMAZONAS, 2014, p. 61).

N45 - Onça é uma unidade de medida de massa para a cotação mundial de ouro, 1 onça equivale em média a 28, $3495 \mathrm{~g}$. A empresa canadense Belo Sun, com sede em Toronto e ações em bolsa de valores internacionais, empreende, desde 2010, um processo de desafetação da área do entorno da Vila da Ressaca, na cidade de José Porfírio, Pará, por meio de compras de terrenos e/ou expulsão de moradores da área.

Fonte: (https://br.reuters.com/article/idBRKCN1U72LU-OBRBS).

N46 - Trecho extraído do Relatório de Impacto Ambiental (RIMA) emitido pela secretaria de Estado de Meio Ambiente do Estado do Pará (BRANDT, 2012, p. 2) sobre o Projeto Volta Grande elaborado pela empresa Belo Sun Mineração Ltda.

N47 - Fala do professor Elielson Silva (SILVA, 2019), pesquisador do projeto "Nova Cartografia Social da Amazônia" (PNCSA), em entrevista por ele concedida ao jornal “Amazônia Notícia e Informação". Com a colaboração da comunidade já afetada pela implantação do projeto de mineração da mineradora "Belo Sun" na região da Volta Grande do Xingu, tal projeto desenvolve a elaboração de mapas cartográficos sobre o espaço geográfico, afetivo, laboral e mitológico da comunidade afetada. 
N48 - Fala de José Pereira Cunha, garimpeiro da região da Volta Grande do Xingu (PNCSA-2018).

N49 - Réplica da jangada pré-colombiana construída pela comunidade indígena dos Muisca que habitava a região geográfica que, atualmente, corresponde ao centro da Colômbia. Nela se realizava a Cerimônia do Eldorado. A jangada original faz parte do acervo do Museu do Ouro em Bogotá, Colômbia.

Fonte: (https://en.wikipedia.org/wiki/Muisca_raft).

N50 - Fragmento de uma peça teatral do escritor e dramaturgo ateniense Menandro (342 a.C. - 291 a.C.) citado na Primeira Epístola do apóstolo Paulo aos Coríntios, capítulo 15, versículo 33.

N51 - Fala do narrador-escrivão português, no filme de (CALDEIRA, 1977), encarregado em reportar para o rei de Portugal detalhes da caça ao líder manaó Ajuricaba. Essa fala se transcorre ao longo de uma cena ilusionista na floresta amazônica, em que os soldados portugueses supõem ter encontrado Ajuricaba, apontam armas para ele, mas ele se transforma numa onça pintada e, em seguida, numa serpente. A cena se transcorre ao longo do segmento fílmico que vai de $1 \mathrm{~h} 10 \mathrm{~min} 18 \mathrm{~s}$ até $1 \mathrm{~h} 10 \mathrm{~min} 30 \mathrm{~s}$. Em seu livro intitulado Imaginário da serpente de $A$ a $Z$, Maria Goretti Ribeiro esclarece que o ritmo dinâmico dos movimentos da serpente "está associado aos ciclos existenciais: mudando de pele periodicamente, aparecendo, desaparecendo e reaparecendo, fluindo da terra como a água, a serpente é o triplo símbolo da transformação temporal, da fecundidade e, por fim, da perenidade ancestral. A capacidade de rejuvenescer com a troca de pele simboliza o processo de transformação bioenergética engajada à esfera do tempo psico-espiritual, uma forma de se compreender a perenidade evolucional do conhecimento e da emanação iniciática. Representa o poder da vida, engajado na esfera do tempo, e o da morte, não obstante eternamente viva. O mundo não é senão a sua sombra - a pele rejeitada. Rápida como um raio, sai de qualquer lugar escuro e quente, de qualquer abertura, de qualquer fenda, lambendo a terra, espreitando, enroscando-se, emboscando, surpreendendo, engolindo, para retornar ao seu mundo trevoso onde parece permanecer imóvel no mistério atemporal de sua própria solidão e completude. Vivendo debaixo da terra, a serpente não só recepta o espírito dos mortos, como também possui os segredos da morte e do tempo: senhora do futuro do mesmo modo que detentora do passado, é animal mágico. Sua presença é uma hierofania visto que ela surge, inesperadamente, como deusa da morte e mergulha, num átimo de segundo, no "invisível”, trazendo e levando o enigma de sua natureza estranha que inspirou histórias fabulosas e enigmáticas, conservadas no inconsciente coletivo de todos os povos da terra" (RIBEIRO, 2017, p. 10-11). Ainda segundo Ribeiro, Anaconda é o nome de "uma imensa serpente que habita os rios da América Latina e que inspirou muitas lendas e mitos. Os índios sul-americanos acreditavam que a inundação Yanomamo recuou quando uma mulher mergulhou nela e se tornou o monstro-cobra. O primeiro africano de Ceuta emergiu como uma Anaconda e se tornou humano após trocar de pele. A Desana (povo indígena da família linguística tucano que habita as margens dos rios Tiquié e Papuri, no Amazonas), que tinha o corpo de Anaconda, emergiu do submundo aquático numa canoa” (RIBEIRO, 2017, p. 22). 
N52 - (SLATER, 1994, p. 81). Fala de um garimpeiro presente nos estudos de de Salter sobre narrativas mitológicas dos mesmos na região de garimpo.

N53 - Trecho do poema de amor intitulado Apolo e Dafne do poeta romano Públio Ovídio Naso (43 a.C. - 18 d.C.), mais conhecido como Ovídio (2003, p. 22-23). Extraído da obra Metamorfoses de Ovídio, o poema envolve também os personagens mitológicos Cupido e Peneo, pai de Dafne, deus dos rios na mitologia grega. Tornada pública no ano 8 d.C., a obra Metamorfoses é composta por 250 narrativas que, como indica o próprio título, intencionalmente rompem a fronteira entre realidade vivida e realidade imaginada e, por extensão, as fronteiras que separam os seres humanos, dos demais seres naturais - animais, vegetais ou minerais -, como também, a fronteira que separa o mundo natural do mundo sobrenatural ou divino. Assim, as narrativas poético-imaginárias de Ovídio dissolvem a distinção entre narrativas vivenciais, mitológicas e literárias, apresentando um mundo em incessante transformação, em que os seres se metamorfoseiam em outros seres para atingirem propósitos diversos, também eles desconhecedores de fronteiras jurídicas, éticas ou religiosas, tais como elas se nos apresentam no mundo contemporâneo. Tudo vale: amor, incesto, ciúme e crime. A escultura intitulada Apolo e Dafne (1622-1625) é de autoria do escultor italiano Gian Lorenzo Bernini (1598-1680) e pertence ao acervo da Galleria Borghese, em Roma. Fontes: (https://pt.wikipedia.org/wiki/Metamorfoses); (https://pt.wikipedia.org/wiki/Apolo_e_Dafne).

N54 - Fala do narrador ao longo da cena de uma canoa navegando pelo Rio Negro, transportando, em seu interior, Ajuricaba, sua companheira e um outro companheiro manaó, acorrentados uns aos outros pelas mãos e pescoços, bem como outros dois indígenas - supostamente manaós traidores e delatores, um armado e outro remando e conduzindo a canoa rio adentro -, para serem entregues ao seu caçador português - Belchior Mendes de Moraes - que os esperava em terra. Quando se dá o encontro entre Ajuricaba e Belchior, o santo guerreiro, representante dos interesses da Coroa Portuguesa na colônia, empunhando a bandeira do reino de Portugal e Algarves e olhando para o infinito da linha do horizonte do rio, diz mais para si próprio do que para o líder manaó: "Sou Belchior Mendes de Moraes. E nunca perdi uma guerra. Mando no rio, na floresta e serei o futuro rei de Eldorado". A cena total transcorre ao longo do intervalo fílmico (1h23min05s até $1 \mathrm{~h} 24 \mathrm{~min} 38 \mathrm{~s})$.

N55 - Ajuricaba, acorrentado à companheira e ao companheiro manaós, sob a vigilância armada do seu caçador português, de outro capanga e de dois indígenas traidores, planejando a sua liberdade - e a sua vingança muda -, momentos antes de quebrar e se livrar da corrente. Foto por Antonio Miguel de cena do filme de (CALDEIRA, 1977, 1h25min04s).

N56 - Foto artisticamente transfigurada por Antonio Miguel de cena (1h26min24s) do filme Ajuricaba, o rebelde da Amazônia (CALDEIRA, 1977). Os raros estudos historiográficos acerca do destino do líder político Ajuricaba, após a sua planejada fuga vingada através das águas do Rio Negro, são controversos e não conclusivos. A versão do colonizador é a de 
que Ajuricaba teria se suicidado, dada a improvável condição de sobrevivência sob as águas do rio e sob a vigilância armada do olhar de Belchior Mendes de Moraes.

N57 - Foto artisticamente transfigurada por Antonio Miguel de cena do filme (CALDEIRA, 1977), transcorrida no intervalo (1h26min42s até $1 \mathrm{~h} 27 \mathrm{~min} 03 \mathrm{~s})$, ao longo do qual o caçador português Belchior Mendes de Moraes - de costas para a câmera e com olhar fixo para lá onde o rio negro anoitecendo encontra a linha do horizonte do céu quase noturno, e com um resto de sol se pondo no horizonte -, apresenta esta fala carregada de ódio, vingança e poder colonial - mas também, de manifesta impotência ao ver Ajuricaba, a sua prometida caça, ousar uma fuga quase impossivel através de um mergulho premeditado por Ajuricaba - mas imprevisto por Belchior - nas águas do Rio Negro.

N58 - Em sua tradução para o português das "Observações sobre o Ramo Dourado de Frazer” de Wittgenstein (WITTGENSTEIN, 2011), o professor João José R. L. de Almeida esclarece do seguinte modo o aforismo de Wittgenstein: "Mergulhar na água da dúvida é o procedimento terapêutico da filosofia". Segundo Almeida, para Wittgenstein, deve-se mergulhar na água da dúvida "[...] não pela própria dúvida, nem pela relatividade dos conceitos, mas apenas contra a nossa irrefreável tendência à generalização e ao dogmatismo. Por isso, o filósofo só se sente à vontade no "caos conceitual". Levando os conceitos problemáticos, aqueles com os quais não nos sentimos satisfeitos, até ao paradoxo, até o ponto de suspensão de seu sentido, o filósofo terapeuta pode relativizar a sua universalidade e a sua necessidade. Ficamos livres para escolher" (WITTGENSTEIN, 2011, nota 215, p. 192, grifo nosso). Nessa mesma nota, Almeida nos apresenta também dois outros aforismos de Wittgenstein que reafirmam este aspecto da atitude metódica terapêutico-gramatical no modo de se lidar com um problema: "Aqui parece que uma dúvida se estende sobre tudo e se precipita no caos" (WITTGENSTEIN, 2012, DC-\$613, p. 339); “Quando filosofamos, devemos descer ao caos primordial e nos sentirmos como se estivéssemos em casa" (WITTGENSTEIN, 2000, p. 98/1948). Assim, a atitude terapêutica que estamos aqui praticando para se lidar com os modos como a prática do pega-cruz, no filme de Mitevska (2019), e a prática de resistência organizada por Ajuricaba ao empreendimento colonizador português, no filme de Caldeira (1977), afetam diferentemente corpos que delas participam está ciente de que o nosso mergulho reiterado nas águas do rio da dívida é de natureza bem diferente do mergulho casual de Petúnia nas águas do rio Otinja, do mergulho premeditado de Ajuricaba nas águas do Rio Negro e do mergulho voluntário de Jesus Cristo nas águas do rio Jordão. A metáfora do mergulho nas águas do rio da dúvida é retomada por Wittgenstein, agora com mais força e poder performativo, na seguinte passagem do seu Da certeza: "Mas não tenho a minha imagem de mundo porque me certifiquei da sua correção; também não é porque dela estou convencido. Ela é antes o pano de fundo herdado da tradição e sobre o qual diferencio entre verdadeiro e falso. As proposições que descrevem essa imagem de mundo poderiam pertencer a um tipo de mitologia. E o seu papel é semelhante ao das regras de um jogo, e o jogo também pode ser aprendido puramente na prática, sem qualquer regra explícita. [...] A mitologia pode pôr-se em movimento, o leito do rio de pensamentos pode deslocar-se. Mas diferencio entre o movimento das águas no leito do rio e o deslocamento desse leito; embora não exista uma separação precisa entre ambos. [...] Sim, a margem daquele rio consiste parcialmente em 
rocha dura, que não é sujeita a alteração ou é sujeita só a uma alteração imperceptível, e em parte em areia, que é arrastada e se deposita, ora aqui, ora ali" (WITTGENSTEIN, 2012, DC-\$ 94-99, p. 143-145). Esta passagem ajuda a esclarecer os usos que Wittgenstein faz das palavras verdade ou certeza, e, por extensão, também das palavras falsidade ou erro e dúvida, para o que ele recorre à imagem analógico-figurativa do leito de um rio, isto é, do caminho percorrido pelas águas fluentes de um rio, em contraste com a ilusória ou enganosa solidez, fixidez e imutabilidade de suas margens, que também mudam a longo prazo, ainda que num ritmo imperceptível quando comparado ao ritmo de fluência das próprias águas. Uma imagem para esse modo duplamente, mas diferentemente, fluido de Wittgenstein conceber as nossas verdades ou certezas é a de, por exemplo, uma cruz de madeira à deriva na correnteza das águas de um rio, como aquela lançada pelo pároco Kosta nas águas do rio Otinja, no filme de Mitevska, dado que tanto a cruz quanto as águas se movimentam, mas apenas as águas no ritmo da correnteza. A cruz de madeira representa a enganosa solidez das margens, isto é, das nossas certezas, ao passo que as águas fluentes representam o turbilhão das nossas dúvidas, incertezas, erros. Para Wittgenstein, a certeza da correção de nossa imagem do mundo decorre do fato dessa imagem constituir o pano de fundo herdado da tradição. São, portanto, os costumes, os usos, os hábitos e as práticas tradicionais de uma forma de vida que constituem nossas verdades e certezas e, portanto, os critérios diferenciadores que usamos, sem perceber, para distinguirmos entre o verdadeiro e o falso, o normal e o anormal, o belo e o feio, o justo e o injusto etc., critérios estes entretecidos na gramática orientadora de uma forma de vida. Este modo metafórico de se falar sobre a certeza como se ela fosse uma cruz de madeira à deriva na correnteza das águas de um rio, sob um pano de fundo herdado de uma prática tradicional que lançou a cruz ao rio motivando pessoas a irem ao seu encalço, nos remete ao seguinte aforismo de Blaise Pascal (1623-1662): "Dizem que o bábito é uma segunda natureza; quem sabe se a natureza não é o primeiro hábito". Este aforismo, quando subtraído do contexto bíblico de sua enunciação, esclarece, a nosso ver, o que Wittgenstein estaria significando com a expressão "pano de fundo herdado da tradição". Assim, para ele, as nossas certezas, tal como também as nossas dúvidas, têm um caráter fluido, ou seja, elas também se movimentam, de modo que as nossas certezas não constituem um edifício em cuja estrutura poderíamos ancorar os nossos saberes, as nossas práticas, os nossos jogos de linguagem. É por isso que os nossos jogos de linguagem são imprevisíveis e as nossas práticas não podem ser explicadas ou suportadas por quaisquer teorias supostamente fundantes ou explicativas, pois práticas e jogos de linguagem são como cruzes de madeira à deriva nas águas fluentes do rio das dúvidas. A imagem arquitetônica da certeza é abandonada e substituída pela imagem líquida do leito ou curso das águas fluentes de um rio constrangidas pelas margens também, mas não igualmente, fluentes do rio.

N59 - "Minhas hipóteses não são inventadas" (NEWTON, 1729, p. 3). Aforismo de Isaac Newton que aparece no "General Scholium" acrescido como apêndice à segunda edição (1713) de sua obra Philosophiae Naturalis Principia Mathematica (Os Princípios Matemáticos da Filosofia Natura), originalmente publicada em 5 de julho de 1687. Newton usava a palavra hipótese para nomear apenas e tão somente as proposições que ele acreditava poderem ser deduzidas da observação direta ou indireta dos fenômenos naturais, razão pela qual, para ele, as suas hipóteses não eram vistas como invenções, mas sim, como descobertas 
baseadas em observações e experimentações. Apenas tais hipóteses poderiam ter lugar em sua filosofia natural tida como estritamente experimental.

N60 - Aforismo de Wittgenstein (2003, p. 171) em explícito contraste com o de Newton (a que fizemos referência na Nota 59), tanto no que se refere ao modo de se significar a palavra hipótese quanto ao modo como as hipóteses científicas se constituem e à relação que estabelecem com outras proposições científicas. Wittgenstein as via como modos linguístico-proposicionais, simbólico-matemáticos ou imagéticos de representação não propriamente de uma realidade ou de fenômenos genéricos, mas daquilo - ou do aspecto daquilo - que se mostra diretamente e está, portanto, diretamente acessível à visão e, consequentemente, às possibilidades de descrição linguística, simbólico-matemática e/ou imagética: "A melhor comparação para qualquer hipótese, - alguma coisa que é, ela própria, um exemplo de hipótese - é um corpo em relação com uma série sistemática de visões dele a partir de ângulos diferentes. [...] Há uma distinção essencial entre proposições como "Aquilo é um leão", "O sol é maior do que a Terra", e proposições como "Os seres humanos têm duas mãos". Proposições como o primeiro par contêm um "isto", um "agora", um "aqui" e, portanto, ligam-se imediatamente à realidade. Mas se acontecesse de não haver nenhum ser humano por perto, como eu faria para verificar a terceira proposição? São sempre faces únicas das hipóteses que são verificadas. E o que uma hipótese explica só é expressável por uma hipótese. [...] Se esta face de uma hipótese é confrontada com a realidade [refiro-me à experiência imediata], ela se torna uma proposição" (WITTGENSTEIN, 2003, p. 170-171, grifo original do autor). Portanto, para Wittgenstein, uma hipótese não está em relação causal ou lógico-inferencial com os fenômenos, dado que ela simplesmente descreve - em uma linguagem nativa, simbólicomatemática, gráfica ou imagética -, um aspecto de um fenômeno. E é nesse sentido que uma hipótese que se pretende uma proposição ou lei científica é sempre uma invenção e não uma descoberta, dado que, para Wittgenstein, tal hipótese, a rigor, não explica (isto é, não é a causa do) o fenômeno que ela supõe explicar e nem é dedutível ou derivada de observações do fenômeno ou de aspectos do fenômeno do qual ela supõe derivar-se, com pensava Newton. Ela é tão somente uma forma possivel de representação-descrição que pode revelar-se mais ou menos potente, mais ou menos útil para se atingir determinados propósitos sociais, comparativamente a inúmeras outras formas de representação-descrição desse mesmo fenômeno voltadas a cumprir propósitos sociais distintos. E formas de representação se mostram mais ou menos adequadas em relação à contemplação dos respectivos propósitos sociais a que visam alcançar, não podendo ser vistas como espelhos mais ou menos fiéis de uma realidade genérica e abstrata ou de aspectos particulares de fenômenos isolados determinados.

N61 - (WITTGENSTEIN, 2005, OF-228, p. 235). Como esclarece Glock (1998, p. 84), para Wittgenstein, "as leis naturais não descrevem necessidades no mundo, uma vez que a única necessidade possível é a necessidade lógica. Na verdade, elas sequer fornecem explicações sobre por que as coisas acontecem do modo como acontecem. Na ausência de necessidades físicas, o que acontece no mundo é uma questão de simples contingência; fornecer explicações com base no funcionamento de leis naturais invioláveis não é melhor do que fazê-lo evocando-se o destino". 
N62 - (WITTGENSTEIN, 2011, p. 194). Com base em seus modos de significar as palavras hipótese e explicaşão, Wittgenstein censura aqui o desejo cientificista de explicação que orienta e perpassa toda a obra aqui referida de Frazer (1982).

N63 - (WITTGENSTEIN, 2011, p. 196, grifo nosso). No filme de Mitevska (2019), sob uma perspectiva wittgensteiniana, a prática ritualístico-religiosa do pega-cruz pode também ser vista como uma prática simbólica ou, em termos derridianos, como uma prática referencial, citacional ou remissiva. Para Wittgenstein, práticas simbólicas são práticas de tradução de práticas efetivas ou diretas por outras práticas efetivas on diretas que a elas faz̧em referências, citações, remissões e, portanto, como práticas de tradução de jogos de linguagem por jogos referenciais, citacionais ou remissivos de linguagem que fazem usos de signos diferentes daqueles mobilizados nos jogos traduzidos de linguagem aos quais os jogos tradutores se referem. Por exemplo, as práticas mágicosimbólicas de queimar ou de beijar a fotografia ou o nome de uma pessoa remetem, citam ou fazem referência, respectivamente, às práticas efetivas ou diretas de matar ou de beijar a mesma pessoa de carne e osso, em que a pessoa de carne e osso é substituída pela sua fotografiasigno ou por seu nome-signo. Para Wittgenstein, práticas ou jogos simbólicos de linguagem não visam, entretanto, a qualquer propósito efetivo, são atos que têm um fim em si mesmos e não poderiam ser interpretados como se os agentes estivessem acreditando na efetividade do ato, isto é, como se acreditassem que, por exemplo, as práticas mágico-simbólicas de queimar ou de beijar a fotografia ou o nome da pessoa que se beija tivessem, respectivamente, o poder de efetivamente matá-la ou de fazê-la sentir-se beijada. Do mesmo modo, para ele, as práticas simbólico-religiosas da confissão de pecados ao sacerdote-confessor e a prática simbólico-religiosa do batismo de uma criança realizado pelo sacerdote católico-cristão são práticas citacionais ou referenciais que remetem, respectivamente, à prática da comunbão - direta e efetivamente realizada por Jesus Cristo, segundo a passagem narrada no Novo Testatamento da última ceia, de conceder a seus apóstolos e a outros cristãos representantes de Deus na Terra o poder de perdoar os pecados cometidos por seres humanos no mundo - e à prática do batismo, efetiva e diretamente realizada de Jesus Cristo, no Rio Jordão, pelo profeta João Batista, também narrada em passagem bíblica do Novo Testamento. Dado, portanto, o caráter simbólico tanto das práticas mágicas quanto das religiosas, não faz sentido, para Wittgenstein, o desejo frazeriano de explicá-las cientificamente, isto é, de se querer avaliá-las ou julgá-las - assentindo-as ou condenando-as - em seus supostos poderes efetivos de atingirem os propósitos almejados, uma vez que elas não visam a quaisquer propósitos que não se consumassem no próprio ato de realização dessas práticas rituais ou cerimoniais. Além disso, é claro que tais práticas ou jogos simbólico-rituais de linguagem não poderiam ser interpretados, como o fez Frazer, como se as pessoas que delas participassem - o sacerdote e o confessante, na prática de confissão, ou, o sacerdote, a criança que se batiza e os seus familiares, na prática do batizado - estivessem acreditando na efetividade do poder do sacerdote de, respectivamente - na qualidade de figura simbólica representativa de Cristo, na prática da confissão, ou de figura simbolólica representativa do profeta João Batista, na prática do batismo -, perdoar os pecados do confessante ou lavar os pecados originais inatos das crianças que são banhadas, por imersão ou não, na água do batismo. Entretanto, sob uma perspectiva wittgensteiniana, embora a prática católico-ortodoxa do pega-cruz devesse também ser vista como uma prática mágico-religiosa de natureza simbólico-referencial, não é assim que os rapazes- 
rebanho do filme de Mitevska (2019) a significam. Tal como Frazer, eles a levam radicamente e literalmente a sério, isto é, acreditam na efetividade do prêmio de prosperidade ao vencedor da prova contido na predição da promessa. E é essa transfiguração de uma promessa simbólica numa hipótese performativa que o futuro deverá confirmar que faz com que eles reajam de modo violentamente fanático, preconceituoso, machista e vingativo em relação a Petúnia, rejeitando categoricamente que ela tivesse sido a vencedora da prova. Neste sentido, a falsa imagem que os rapazes-rebanho fazem da prática mágico-simbólico-religiosa do pega cruz, qual seja, a de transfigurar uma promessa simbólica em uma bipótese de poder performativo, os leva a ver a vencedora da prova como uma ladra, como alguém que cometeu um crime por transgredir as regras de um jogo religioso tradicional de linguagem. Por isso, ela merece, segundo eles, uma dupla condenação: uma condenação legal, por ter supostamente cometido o crime de roubar um objeto sagrado; e uma condenação religiosa, pelo fato da prática do roubo ser também vista como uma transgressão pecaminosa, à luz da tábua mosaica dos dez mandamentos, do jogo de linguagem penal divino.

N64 - Esta crítica de Wittgenstein (2011, p. 192-193; p. 196) recai sobre o pressuposto cientificista que orienta a narrativa historiográfico-antropológica whig de Frazer na sua obra $O$ ramo dourado (FRAZER, 1982), pressuposto este que o leva a construir uma falsa imagem da prática de sucessão do sacerdócio de Nemi (Ver Notas 34, 35 e 36). Segundo Wittgenstein, esta falsa imagem se produz através de um mecanismo ilegítimo de 'cientificização' de uma prática dogmático-religiosa e, portanto, de uma prática de natureza simbólico-ritualista, em uma hipótese científica aberta à verificação ou refutação empíricas e a explicações racionais, dado que, sob a perspectiva positivista, explicações historiográfico-antropológicas - como quaisquer outras explicações de natureza científica - devem participar do estágio positivo final de um processo epistemológico-explicativo evolutivo, linear e universal que vê a observação, a experimentação e a produção de leis reguladoras dos fatos - naturais e/ou sociais - como critérios últimos e definitivos de validação das explicações científicas. A objeção que faz Wittgenstein ao desejo frazeriano de explicar cientificamente uma prática dogmáticoreligiosa e, portanto, metafísica, é da mesma natureza que a objeção feita ao desejo inverso de explicar dogmaticamente, isto é, através de teorias metafísicas, uma hipótese científica para a qual, portanto, é possível acumular um conjunto de evidências empíricas que a reforcem ou que a refutem. É por isso que, para ele, não há nada de errado com Agostinho, com Buda ou com qualquer outra prática dogmática de caráter religioso ou mágico, a não ser quando se manifesta e se leva adiante o desejo de teorizá-las, de explicá-las cientificamente, isto é, quando se tenta assentar a fé na razão, racionalizar ou explicar racionalmente a fé, como o fizeram, por exemplo, as inúmeras 'provas científicas' da existência de Deus ao longo da história da filosofia e da religião. Ou então, quando ao cientista se manifesta o desejo oposto de assentar a razãa na fé, isto é, de transcendentalizar a raz̃ão, de explicar o fenômeno ou problema sob investigação empirica com base em teorias metafísicas, transcendentais, inacessíveis, elas próprias, ao controle observacional ou experimental-perceptual. E é aí que se manifesta o erro de Frazer, segundo Wittgenstein. Por um lado, é uma característica saliente da crítica terapêutica de Wittgenstein identificar e considerar errônea a atitude de Frazer de desejar explicar cientificamente o que não pode ser cientificamente explicado, isto é, a atitude de Fražer de tentar racionalizar o dogma. Por outro lado, ao acusar de errônea a invisibilidade do olhar de Frazer para a natureza simbólica das práticas mágicas e religiosas, Wittgenstein também 
nos leva a ver como legítima a atitude terapêutica de explicar o desejo de Frazer de explicar o que não pode ser explicado cientificamente, quando o próprio Wittgenstein procura explicar a imperiosidade de tal desejo pela sua invisibilidade em relação à natureza simbólica das práticas mágicas e religiosas. Assim, o desejo de explicar uma prática é explicitamente condenado por Wittgenstein, não o sendo, porém, o seu próprio desejo de explicar o desejo de Frazer de explicar. Estaríamos, então, diante, de dois tipos diferentes de explicação, isto é, de dois usos diferentes da palavra "explicação" - um ilegítimo e outro legítimo - acionados por Wittgenstein em sua crítica terapêutica a Frazer, ou então, seria mais pertinente dizer ser igualmente criticável o desejo de Wittgenstein de mostrar ao leitor o que teria levado Frazer a prender-se a uma imagem distorcida ou falsa das regras gramaticais das práticas mágicas e religiosas, vendo-as não como crenças orientadoras da realização de práticas simbólicas, mas sim, como hipóteses acerca de fenômenos naturais a serem confrontadas com a experiência? É preciso ter presente que o argumento de Wittgenstein contra Frazer não é da mesma natureza que o argumento de Frazer contra as práticas mágicas e religiosas. $\mathrm{O}$ argumento positivista-cientificista de Frazer contra as práticas mágicas e religiosas e, a rigor, contra todas as demais práticas dogmáticas ou metafísicas, é o de que, por serem elas vistas como empiricamente falsas e, portanto, passíveis de refutação empírica, elas deveriam ser vistas como pré-científicas, primitivas, bárbaras, ingênuas, infantis, irracionais etc. e, portanto, eticamente condenáveis. Já o argumento de Wittgenstein contra Frazer é o de que o argumento de Frazer contra as práticas mágicas e religiosas é autorreflexivo, isto é, aplica-se ao próprio argumento de Frazer, desconstruindoo, de modo que o argumento anti-mágico, anti-religioso e anti-metafísico de Frazer é, ele próprio, mágico, religioso e metafísico. Assim, o erro de Frazer foi não ter visto que também o pressuposto gramatical whig que orienta a sua investigação antropológico-historiográfica é, ele próprio, uma crença ou dogma de natureza metodológica que compromete a cientificidade da sua própria investigação. E é para evitar deixar-se seduzir pelo mesmo feitiço que a linguagem preparou a Frazer, que Wittgenstein começa as suas "Observações sobre O ramo dourado de Frazer" (WITTGENSTEIN, 2011) com a seguinte observação autoterapêutica: "Creio agora que seria correto iniciar um livro com observações sobre a metafísica como uma espécie de magia. Ao fazê-lo, no entanto, eu não poderia falar nem a favor da magia e nem faz̧er troça dela. A profundidade da magia teria que ser mantida. - Sim, pois a eliminação da magia teria aqui o caráter de própria magia. [...] Deve-se começar pelo erro e convertê-lo à verdade" (WITTGENSTEIN, 2011, p. 192). Assim, não seria legítimo dizer que Wittgenstein "explica" - e, muito menos, que "explica cientificamente" - o desejo cientificista de Frazer no mesmo sentido em que Frazer deseja explicar - e, mais do que isso, explicar cientificamente - as práticas mágicas e religiosas. Wittgenstein não transforma o dogma que orienta a historiografia antropológica whig de Frazer em uma hipótese a ser comprovada ou refutada empiricamente. O que faz Wittgenstein é acusar um paradoxo e, portanto, um erro lógico no pressuposto positivista-cientificista que orienta a investigação de Frazer e, por extensão, toda investigação científica de natureza positivista. Trata-se do paradoxo do mentiroso, cuja formulação mais concisa se expressa na proposição "Minto". Pois, se suponho ser esta minha afirmação verdadeira, então, eu estou mentindo e, portanto, a afirmação de que minto é falsa; por outro lado, se suponho que ela é falsa, então, eu estou dizendo a verdade e, portanto, a afirmação de que minto é verdadeira. Assim, o argumento de Wittgenstein contra Frazer é tão somente um esclarecimento do feitiço 
linguageiro que nos leva ao desejo de transformar crenças ou dogmas que orientam as práticas religiosas e mágicas em hipóteses científicas. Tal feitiço não é senão o do poder performativo de uma imagem cientificista dos problemas que são submetidos à investigação, imagem esta que, de tanto ser repetida em nossos jogos de linguagem, adquire um poder hegemônico que acaba aprisionando os nossos modos de ver, falar, interpretar e agir (poder do discurso, diria Foucault). "Uma imagem nos mantinha presos. E não pudemos dela nos livrar porque ela residia em nossa linguagem, que a repetia para nós inexoravelmente" (WITTGENSTEIN, s/d, IF-115). É tal mecanismo de poder iterativo de nossos jogos de linguagem que, segundo Wittgenstein, nos leva a produzir "falsas imagens" ou "imagens ilusórias" dos problemas que investigamos ou com os quais nos ocupamos, bem como a agir ou reagir dogmaticamente, irracionalmente, preconceituosamente ou mesmo violentamente a tudo aquilo que nos é estranho, estrangeiro, que nos causa estranhamento e nos desestabiliza.

N65- Fala de Belchior, personagem do no Belchior fora enviado como representante da Coroa Portuguesa para capturar Ajuricaba, índio que comandava levantes contra a invasão portuguesa no território amazônico. Acusava-se a comunidade indígena dos manaós de associação e cumplicidade com os holandeses na exploração de ouro e fornecimento de escravos; contudo, para Gusman (1997) não há evidências ou registros históricos que confirmem tal aproximação e acordo.

N66 - Tese em favor da qual argumenta o antropólogo francês Claude Lévi-Strauss no capítulo VII, intitulado $A$ ilusão arcaica, do seu livro As relações elementares do parentesco (LÉVISTRAUSS, 1982, p. 131). Para ele, pensadores como Freud, Blondel, Piaget e Jung, entre outros, teriam se deixado seduzir pela imagem ilusionista arcaica de se querer "ver nas sociedades primitivas uma imagem aproximada de uma mais ou menos metafórica infância da humanidade, cujos estágios principais seriam reproduzidos também, por sua parte, no plano individual, pelo desenvolvimento intelectual da criança" (LÉVI-STRAUSS, 1982, p. 126-127).

N67 - Conversa sobre os manaús transcorrida na casa grande, entre portugueses colonizadores, após o governador da Província declarar guerra justa contra os manaús liderados por Ajuricaba, apesar do protesto do reitor do colégio dos jesuítas, no filme (CALDEIRA, 1977). O segmento fílmico no qual transcorre essa conversa é (00h36min09s até $00 \mathrm{~h} 38 \mathrm{~min} 17 \mathrm{~s})$.

N68 - Conversa (1h03min), em tom confidencial, entre Petúnia e o policial Darko, após ela ter sido levada à delegacia de polícia para prestar depoimento, no filme de Mitevska (2019).

N69 - Foto por Antonio Miguel de cena do filme de Mitevska (2019). É interessante observar que, na prática tradicional católico-ortodoxa do pega-cruz, a cruz de madeira que é lançada ao rio pelo pároco - e que é resgatada por Petúnia - leva atado, com um barbante cor de vinho, um ramo dourado de trigo ao longo do seu braço maior, ramo este remanescente de um buquê mais farto de flores e cereais atado à cruz antes do seu lançamento na correnteza do rio, cruz esta à qual fizemos referência na Nota 14. Observe-se também 
que, ao longo dos dois braços da cruz de madeira, o artesão entalhou o que parece poder ser visto como uma representação simbólica estilizada, em alto relevo, de ramos entrelaçados de trigo ou de alguma outra planta ou flor, detalhe este que, devido à sua forma, nos remete a versões de cruzes coptas usadas, ao longo do tempo, pela Igreja católicoortodoxa egípcia ou copta, tal como o atestam as inúmeras versões de cruzes hoje vistas como objetos de arte copta, como o são, por exemplo, as duas primeiras imagens, da direita para a esquerda, que apresentamos no segmento N12 deste texto. A pertinência desta remissão se baseia na semelhança formal entre o padrão geométrico de entrançamento fibrático regular e simétrico esculpido em alto relevo ao longo dos dois braços da cruz de madeira do filme que é lançada ao rio e o padrão geométrico de entrançamento simétrico e regular, nas cores azul e amarelo vibrantes, desenhado ao longo dos dois braços do emblema da cruz copta. Das duas versões de cruzes copta que apresentamos no segmento N12, a que mais se assemelha à cruz lançada ao rio no filme de Mitevska (2019) é, sem dúvida, a última cruz à direita. Por sua vez, o ramo dourado de trigo e o barbante cor de vinho que o ata à cruz lançada ao rio no filme poderiam estar funcionando, respectivamente, como símbolos simultaneamente metafóricos e metonímicos do pão, para o corpo de Cristo, e do vinho, para o sangue de Cristo compartilhados por Jesus entre os seus apóstolos, na última ceia feita com eles antes da sua condenação e cruxificação. Esses elementos materialmente simbólicos agregados à cruz lançada ao rio no filme nos remetem também à imagem esculpida da deusa grega do acaso - Tique de Antioquia (ver segmento textual N3 e a Nota N3 a ele correspondente) - que segura em sua mão direita um ramo de trigo como símbolo de prosperidade e de boa sorte, o que nos leva a conectá-la diretamente ao aspecto cristão-ortodoxo-copta sagrado da prática simbólicoritual do pega-cruz, cujo prêmio é a promessa de boa sorte e prosperidade para quem conseguir encontrar e retirar a cruz à deriva no fluxo caótico da correnteza do rio. Por outro lado, o fato da estátua de Tique estar afogando impiedosamente, com o seu pé direito, uma figura masculina nas águas do rio Orontes, que corre nos territórios atuais do Líbano, Síria e Turquia, nos leva a conectar a deusa do acaso Tique profanamente com a prática do pegacruz, sugerindo uma transgressão dos valores patriarcais e machistas mobilizados por essa prática, o que conecta a deusa Tique, no filme de Mitevska (2019), ao ato transgressivo casual de Petúnia, bem como, é claro, ao nome transgressivamente provocador do próprio filme que sugere ser Deus uma mulher de nome Petúnia. Assim, a cruz de madeira com um ramo de trigo entalhado em seu braço e atado com barbante cor de vinho ao longo do braço maior, à deriva na correnteza do rio, e que é resgatada por Petúnia, parece funcionar como uma chave multisimbólica estruturante do sentido da narrativa fílmica. Sob uma perspectiva wittgensteiniana, para o grupo de rapazes que se envolvem com a prática do pega-cruz, ela aparece como um jogo simbólico de linguagem, isto é, como um jogo referencial ou remissivo de linguagem que, dentre outros, também poderia estar remetendo à passagem bíblica do Novo Testamento conhecida como a santa ceia. Mas apenas os doze apóstolos de Cristo - todos bomens - participaram da ceia. Não há registro de mulheres entre os apóstolos, o que poderia, talvez, esclarecer o fato da prática do pega-cruz estar tradicionalmente restrita a homens. Porém, é quase impossível não se notar o contraste entre o símbolo sagrado cruz e a sensual toalha verde com bolinhas brancas - que, em nossos dias, remete ao universo do vestuário feminino - escolhida (por acaso?) por Mitevska (e também por Petúnia?) para embrulhar a cruz e escondê-la em seu quarto antes de ser conduzida à delegacia de polícia da cidade. Esta escolba, talvez intencional por parte da diretora do filme, mas casual por parte 
de Petúnia, por não ver, nessa escolha profana casual, uma transgressão à prática sagrada simbólico-católico-ortodoxo-masculina, cuja simbologia ela parece desconhecer, sugere que Petúnia se apropria da cruz que participa desse jogo simbólico-sagrado de linguagem e, transfigurando-o, a faz participar de um jogo sexualmente profano de linguagem, no qual a cruz passa a ser significada como um símbolo fálico. Fonte: (https://sttakla.org/Gallery/search.html?q=coptic+icon).

N70 - Foto por Antonio Miguel de cena do filme de Mitevska (2019).

N71 - É com base nessa 'argumentação' que, no filme de Mitevska (2019, segmento $1 \mathrm{~h} 04 \mathrm{mim}$ a $1 \mathrm{~h} 05 \mathrm{~min} 54 \mathrm{~s}$ ), os rapazes-rebanbo de Shtip - é assim que o pároco da cidade, Kosta, a eles se refere, como rebanho, e talvez tenha sido intencional e por razões semelhantes, por parte de Mitevska, não atribuir nome a qualquer uma das ovelhas desse rebanho -, colonizados pelo catolicismo ortodoxo, 'justificam' para a jornalista - e, portanto, para toda a cidade -, vendo-as como normal, tanto as suas hostilidades e agressões verbais carregadas de ódio à 'estrangeira' Petúnia, quanto a declaração de uma extemporânea guerra santa contra a 'invasora', através de seu linchamento moral público. $\mathrm{Na}$ perspectiva dos rapazes-rebanho, a conquista da cru₹-prêmio-promessa-de-prosperidade por parte de uma mulher, em uma competição-ritual-religiosa tradicionalmente reservada a homens, é vista como um roubo de um objeto sagrado performativo, isto é, dotado do poder de predizer o futuro do vencedor da prova e realizar a promessa de prosperidade que promete. Portanto, para os rapazesrebanho-competidores de Shtip, Deus é homem machista e seu nome não pode ser Petúnia e nem o nome de nenhuma outra mulher. Assim, a 'estrangeira' Petúnia, por ter 'invadido' o território-patriarcal-masculino, propriedade-herança-do-deus-macho-pai-todo-poderoso, através da 'transgressão das regras' de uma prática constitutiva da identidade masculina e ter conquistado a cruz-prêmio-promessa-de-prosperidade não pode ser vista como vencedora da prova, e sim como uma ladra. E caso ela não lhes devolvesse a cruz-promessa-de-prosperidade, deveria ser apedrejada, como punição pelo seu roubo. Apedrejar ladrões era uma prática cultural justiceira de linchamento público que prevalecia entre os judeus, no mundo antigo, na época em que viveu Jesus Cristo. Mas era uma prática cultural que também se aplicava a prostitutas. E por ser um ladrão do sexo feminino, uma "Maria Madalena ladra", Petúnia deveria ser duplamente condenada e, portanto, duplamente apedrejada: por ser vista como ladra e prostituta. É o que sugere o 'argumento' na fala do último rapaz, dito confidencialmente a ela, sentados em um banco na delegacia de polícia: - "Vaca! Vagabunda! Vadia! Você vai apodrecer no inferno!’.

N72 - Esta foto de Maria Madalena é a ilustração feita por Danielle Storey para a capa do livro Mary Magdalene: Insights From Ancient Magdala ("Maria Madalena, percepções da antiga Magdala") da pesquisadora Jennifer Ristine, lançado em 22 de julho de 2018. Com base em recentes descobertas arqueológicas feitas na cidade de Magdala (atual Migdal, Israel), onde se acredita ter nascido Maria Madalena, Ristine constitui, no referido livro, o perfil desta mulher misteriosa que a Igreja Católica tachou, durante séculos, como adúltera e prostituta (RISTINE, 2018). É bastante citado o aforismo de Jesus, com o qual ele interveio e impediu o apedrejamento de Maria Madalena: "Aquele que nunca cometeu um pecado que atire a primeira pedra". Entretanto, nem a Bíblia cristã e nem a hebraica 
previam a morte por apedrejamento para a prática da prostituição feminina. Segundo Rainer Gonçalves de Sousa, "na Antiguidade Oriental, é comum ouvirmos falar sobre a prática da prostituição com fins rituais. O geógrafo grego Strabo, por exemplo, relatou que os assírios ofereciam suas filhas ainda muito jovens para praticarem a prostituição ritual com aproximadamente 12 anos de idade. Heródoto descreveu de forma repugnante a prostituição babilônica realizada no interior do templo da deusa Ishtar. [...] Alguns historiadores vêm questionando fortemente essas narrativas que vinculam o sexo e a prostituição na antiguidade com algum ato sagrado. Para essa corrente revisionista, a descrição do ato sexual entre algumas civilizações antigas partiu de cronistas e observadores interessados em detrair a cultura estrangeira sob o ponto de vista moral. Além disso, eles buscam e citam, entre os vários povos do Crescente Fértil, a presença da prostituição como meio de sobrevivência e a sua oferta pelas ruas dos centros urbanos. [...] Pecado ou necessidade? Esse era o grande dilema enfrentado pelos clérigos medievais ao se colocarem na difícil tarefa de converter a Europa bárbara e romana ao cristianismo. Sob o aspecto formal, as prostitutas infringiam um dos mais importantes tabus da Igreja ao praticarem a fornicação. Por outro lado, as demandas do mundo cotidiano reiteravam, vez após vez, que o banimento da prostituição era uma missão praticamente impossível. Uma das justificativas mais comuns a manterem a prostituição ativa girava em torno do próprio controle de pecados observados como mais graves. O uso que os homens jovens faziam dos bordéis funcionava como meio para que as mulheres respeitáveis não fossem vítimas de sedução ardilosa e estupro. No fim das contas, seria menos grave violar os limites do corpo de uma mulher que já havia caído em pecado do que desgraçar uma casta seguidora dos princípios morais da Igreja. O próprio Santo Agostinho advertia que o banimento da prostituição seria porta de entrada para outros pecados ainda mais controversos" (SOUSA, s/d-1); (SOUSA, s/d-2).

N73 - O apedrejamento de Santo Estêvão (1603-4) pelo pintor italiano Annibale Carracci (15601609), atualmente no Museu do Louvre. Estêvão (? - 40 d.C.) foi um dos sete diáconos eleitos para pregar o cristianismo em Jerusalem, logo após a morte de Jesus. Ele pertencia a um grupo de cristãos que pregava a prática de um cristianismo radical, o que acabou lhe custando uma condenção por blasfêmia pela suprema assembleia de Jerusalém. A sentença, igualmente radical, foi a morte por apedrejamento. Ele foi o primeiro mártir cristão, dentre outros que seriam também perseguidos e condenados nos primeiros séculos do cristianismo. Foi considerado santo pelos cristãos católicos, ortodoxos e anglicanos. A data de seu martírio é celebrada em 26 de dezembro, no Ocidente, e em 27 de dezembro, no Oriente. A lapidação ou apedrejamento era uma prática legalizada muito antiga de execução de condenados à morte que consistia em que os assistentes lançassem pedras contra o réu até o matar. Como uma pessoa pode suportar golpes fortes sem perder a consciência, a lapidação pode produzir uma morte muito lenta. A lei mosaica, expressa nos primeiros cinco livros tanto da Bíblia cristã como da Bíblia hebraica, prevê a morte por apedrejamento nas seguintes situações: bestialidade - ato sexual entre um humano e um animal não-humano - cometida por homens ou mulheres; blasfêmia, isto é, a difamação do nome de um ou mais deuses, ou mais geralmente, qualquer tipo de insulto religioso ou irreverência para algo considerado sagrado ou inviolável; relações sexuais com enteada, mãe ou madrasta; amaldiçoar os pais; idolatria; instigar indivíduos ou comunidades à 
idolatria; necromancia, isto é, a prática de comunicação com o mundo espiritual para se obter informações do futuro por meio da invocação dos mortos; sacrificar o próprio filho ao deus Moloch; homossexualidade; pitonismo (culto à serpente Píton); rebeldia dos filhos contra os pais; desrespeitar o sabá (do hebraico shabat), dia de descanso semanal no judaísmo; bruxaria. Moloch é o nome do deus de corpo humano com a cabeça de boi ou leão cultuado pelos amonitas, povos de uma etnia de Canaã que viveram na Península Arábica e na região do Oriente Médio por volta de 1900 a.C. Porém, na tradição cristã e cabalística, Moloch é o nome de um demônio, visto que, segundo o antigo testamento da Bíblia cristã, nos rituais de adoração a Moloch, um costume de longa duração, atos sexuais eram praticados e crianças eram jogadas em uma cavidade da estátua de Moloch, onde

eram consumidas ainda vivas pelo fogo. Fontes:

(https://pt.wikipedia.org/wiki/Protomártir);

(https://pt.wikipedia.org/wiki/Annibale_Carracci);

https://pt.wikipedia.org/wiki/Estêvão_(mártir);

(https://pt.wikipedia.org/wiki/Apedrejamento);(https://pt.wikipedia.org/wiki/Lapidaçã o);

(https://www.historiadomundo.com.br/idade-antiga/a-prostituicao-na-antiguidade.htm); (https://www.historiadomundo.com.br/idade-media/a-prostituicao-na-idade-

media.htm);

(https://pt.wikipedia.org/wiki/Protomártir);[https://pt.wikipedia.org/wiki/Estêvão_(m ártir)];

(https://pt.wikipedia.org/wiki/Moloch).

N74 - Fala da jornalista Slavica Janeva (1h31 min37s a $1 \mathrm{~h} 32 \mathrm{minn} 01 \mathrm{~s})$ transmitida ao vivo à população de Shtip, em frente da delegacia de polícia para onde Petunia havia sido levada, no filme de Mitevska (2019).

N75 - Gravura do desenhista, impressor, aquafortista e xilogravurista alemão Virgil Solis (1514-1564) feita em 1581 para o Livro I das Metamorfoses (1556), do poeta romano Ovídio (43 a.C - 17 ou 18 d.C.). Segundo Ribeiro (2017, p. 14), no imaginário coletivo de vários povos - dentre eles os gregos antigos e também os povos ameríndios -, a serpente era vista como detentora de poderes e forças misteriosas ambivalentes: ou divinas e divinatórias ou demoníacas. O poder divino e divinatório parecia atuar, particularmente, sobre o êxito ou o fracasso de um empreendimento, sobretudo bélico, razão pela qual as armas utilizadas pelos guerreiros na defesa de seus povos ou cidades deveriam estar protegidas pelo poder das serpentes. Teria sido tal crença que teria levado os gregos antigos a cultuarem a serpente denominada Piton - tida por eles como filha da deusa Gaia, e por tal razão elevada a uma divindade telúrica sagrada - e a construirem a ela um templo de veneração próprio - o oráculo de Píton - onde eram realizados cultos à serpente e onde uma sacerdotisa denominada pitonisa realizava as suas profecias. O templo de devoção a Apolo - deus da luz, da razão, da sabedoria -, tal como o de Píton, situava-se no santuário de Delfos. Em seu portal, como uma espécie de convite ao autoconhecimento ou ao culto de si mesmo, aparecia o aforismo gnōthi seauton - conbece-te a ti mesmo - do qual não se sabe bem a autoria, ainda que, muitas vezes, seja atribuído a Sócrates. Há diferentes explicações do mito do assassinato da serpente Píton - a guardiã do templo da pitonisa - por Apolo. Segundo uma delas, Apolo, 
filho de uma relação extraconjugal de Zeus com a deusa Leto, teria matado a serpente Píton a flechadas, para se vingar de Hera - deusa da maternidade e da fidelidade conjugal -, esposa de Zeus, que teria enviado a serpente ao templo para matar Leto que, na ocasião, estava grávida de Apolo. Após ter matado a serpente, o deus Apolo, com o propósito de “[...] libertar o oráculo de Delfos dessa hipertrofia das forças naturais" que a serpente Píton representava simbolicamente, acionando a estratégia de humanizar o seu nome divino, mudou-o para Pitius e passou a organizar, a cada nove anos, os denominados jogos pitinianos, exclusivamente reservados a humanos do sexo masculino que concorriam entre si em jogos demonstrativos de força física e rapidez em corridas de carruagem (RIBEIRO, 2017, p. 145). Assim, segundo esta versão do mito, ao bumanizar-se através da bumanização da serpente, isto é, ao transformar os poderes (sobre)naturais divinos e divinatórios da serpente em poderes exclusivamente bumanos e masculinos, o deus Apolo teria tentado inverter ideologicamente um costume, uma crença simultaneamente religiosa e mágica, inversão esta que ao retirar o poder sobrenatural e espiritual da serpente Píton, retirava igualmente o poder espiritual e humano da pitonisa e, por extensão, das mulheres, de modo que a vingança de Apolo em favor de sua mãe humanizando masculinamente a serpente pode também ser vista como uma vingança simbólica contra todas as mães, contra o ato natural exclusivamente feminino da maternidade e, portanto, contra todas as mulheres. Já uma outra versão do mito conta que Apolo havia transformado uma ninfa aquática de nome Castália em uma fonte de água sagrada, pura e cristalina que jorrava ao lado do santuário de Delfos. O mito conta ainda que, nessa fonte, local onde vivia a serpente Píton, as musas costumavam se reunir para cantar ao som da lira de Apolo, razão pela qual acreditava-se que a água, inebriada pelo canto das musas, emitia vapores alucinógenos dotados do poder de seduzir a serpente que, por sua vez, adquiria o poder de fazer com que a pitonisa sonhasse e tivesse visões que lhe permitiam predizer o futuro. Desta vez, porém, por ter matado a serpente, que era a filha da deusa Gaia - a mãe da Terra -, Apolo teria sido punido por essa deusa. Entretanto, uma vez que para a cultura monoteísta judaico-cristã, não só a relação sexual fora do matrimônio, como também o pitonismo - isto é, o culto a serpentes, vistas como seres demoníacos constituíam práticas pecaminosas criminalizadas, a última delas levando os seus adeptos à execução pública por apedrejamento, nenhuma das versões do mito da serpente positivamente vista como um ser divino e divinatório prevaleceu. Ao contrário, o que prevaleceu foi a própria prática de execução pública por apedrejamento, estendida, porém, dos ladrões às prostitutas, vistas como vítimas que teriam sucumbido às tentações sedutoramente alucinógenas dos contos $e$ dos cantos das serpentes. Fonte: [https://pt.wikipedia.org/wiki/P\%C3\%ADton_(mitologia)].

N76 - Pintura em vaso cerâmico grego da época arcaica, atribuída a Makron, produzida por volta da década de 480 a.C. O vaso pertence à coleção do Museu Britânico, em Londres, cujo catálogo descreve do seguinte modo a cena pintada no vaso: "Triptolemus se prepara para partir de Elêusis em uma carruagem alada, puxada por serpentes, em uma missão de instruir a humanidade na agricultura. Deméter e Perséfone, segurando tochas de Elêusis e feixes de trigo, se despediram. Vários outros deuses (não mostrados) são retratados na cena maior". O site do Theoi Greek Mythology, fonte da imagem do vaso e da descrição da cena nele pintada, esclarece ainda que "Triptolemus era um semideus dos mistérios eleusinos que presidia a semeadura de grãos e a moagem de trigo. Ele foi um dos 
príncipes eleusinos que deu hospitalidade à deusa Deméter quando ela estava de luto pela perda de sua filha. Depois que Perséfone voltou do submundo, Deméter generosamente instruiu Triptolemus nos caminhos da agricultura e forneceu a ele uma carruagem alada, puxada por serpentes, para espalhar esta atividade por toda a terra. Ele viajou por muitas terras, mas quando chegou ao reino frio dos skythianos, o rei Lynkos matou uma de suas serpentes-dragão e levou o herói para longe. Deventer transformou o rei em um lince e negou aos skythianos o dom da agricultura. $\mathrm{Na}$ pintura de vasos gregos antigos, Triptolemus geralmente é retratado sentado em sua carruagem alada na companhia das deusas Deméter, Perséfone e Hekate. Ele também aparece em grandes reuniões dos deuses eleusinos". Como dissemos na Nota 14, a deusa grega da agricultura, Deméter, remete, no mundo grego antigo, à deusa Ops, uma vez que todos os jogos artístico-visuais de linguagem - escultóricos ou plásticos - dos quais Ops participa remetem, direta ou metaforicamente, ao campo de atividade da agricultura. Deméter é também uma das versões da deusa romana da Fortuna, qual seja, aquela em que esta deusa aparece empunhando, em uma das mãos, uma cornucópia, isto é, um vaso em forma de chifre repleto de frutas e flores e, na outra mão, ramos de cereais, quase sempre ramos dourados de trigo, simbolizando a fertilidade, a riqueza e a abundância, tanto na vida pessoal quanto nas formas de vida do comércio e da agricultura. Segundo Ribeiro, "as serpentes estão associadas às deusas ctônicas. Deméter, a Mãe Terra minóica, deusa da agricultura, deusa das sementes, especificamente deusa do trigo, estava ligada às cobras. Suas imagens trazem figuras de serpentes e de sementes no mesmo plano de significação. Nos rituais em honra a essa deusa, nos Mistérios de Elêusis, acontecia uma união mística com a serpente, ato apoteótico de grande significado simbólico e religioso" (RIBEIRO, 2017, p. 55). (https://www.theoi.com/Gallery/O28.1.html).

(https://www.theoi.com/Georgikos/EleusiniosTriptolemos.html).

N77 - Passagem de (Gênesis 3,14) acompanhada da composição fotográfica de três jogos artístico-visuais de linguagem que tematizam a tentação de Eva pela serpente, no paraíso: a imagem (inferior) intitulada Lúcifer, a serpente do Jardim do Éden (RIBEIRO, 2017, p.105); o afresco de parede (superior à esquerda) na capela de Santa Maria del Carmine, em Florença, Itália, intitulado A Tentação de Adão e Eva (c.1423-25), do pintor italiano Tommaso Masolino da Panicale (1383-1447); a aquarela sobre papel (superior à direita) $A$ tentação e a queda de Eva (1808), do poeta, tipógrafo e pintor inglês William Blake (17571827), produzida como uma ilustração para a reedição, em 1808, do livro O Paraíso perdido do poeta inglês John Milton (1608-1674). Segundo Ribeiro (2017, p. 15-16), "fonte de terrores, a serpente está enredada com a história evolucional do homem, participando de seus conflitos, dramas e crenças, curando e inspirando artistas literários. Personagem central no episódio da queda do homem, ela se tornou a face sombria da alma, a força etérea do mal, a matéria orgânica do inferno, tornando-se indispensável à gnose e à evolução espiritual. Talvez por isto, os ofitas a veneram e os cristãos a repugnam, embora ela signifique a causa do conhecimento e o impulso para a trajetória humana em busca do Paraíso perdido. Do ponto de vista psicológico, é símbolo da alma, do inconsciente, da libido. Ela representa um complexo de arquétipos ligados à fria e pegajosa escuridão subterrânea das origens, o seu simbolismo está ligado à vida latente, à camada mais profunda da vida, ao espiritual ou integrativo, à força da personalidade, à transformação e 
renovação. Para os freudianos, é símbolo fálico, de evolução psíquica (valência positiva) e de medo, angústia e morte (valência negativa), da sexualidade de modo geral, da sensualidade reprimida ou obsessiva. Freud diz que as serpentes frequentemente representam os interesses, conflitos e atitudes sexuais. Nos sonhos, ela manifesta o inconsciente protetor e garantidor do equilíbrio psíquico global; como guarda, ela impede a entrada à totalidade do ser". Diversamente da imagem hegemônica difundida pelo cristianismo ocidental da serpente como um ser diabólico, indutor da traição e do pecado,

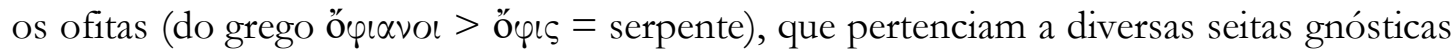
cristãs da Síria e do Egito, no segundo século depois de Cristo, difundiram uma imagem da serpente que se opunha àquela difundida pelo cristianismo ocidental. Para eles, a serpente era vista como mensageira do conhecimento de salvação para os seres humanos. Esta imagem positiva da serpente levou-os a criticar o Deus do Antigo Testamento como sendo um deus misantropo e, particularmente, misógino, uma vez que se manisfestava como um deus vingativo e violento que nutria ódio pela humanidade e, particularmente, pelas mulheres.

Fontes:

(https://pt.wikipedia.org/wiki/Ofitismo). (https://www.emol.com/especiales/2008/arte_cultura_religion/aprendiendo_a_mirar/t entacion.html);

(https://commons.wikimedia.org/wiki/File:William_Blake,_The_Temptation_and_Fall_ of_Eve.JPG).

N78 - Logo após a cena do ritual da procissão de párocos da Igreja Ortodoxa em direção ao rio da cidade, onde será realizada a prova do pega-cruz, o olhar da câmera de Mitevska passeia calmamente por imagens de arte sacra copta de santos cultuados pela Igreja Ortodoxa Bizantina (2019) desenhadas na parede de um mosteiro, supostamente, o mosteiro de Rila, o maior complexo arquitetônico, histórico e artístico da cultura ortodoxo-cristã bizantina da Bulgária, fundado no século X por São João de Rila, um eremita canonizado pela Igreja Ortodoxa. Entre as imagens de santos e santas, destacamse, por contraste entre o sagrado e o profano, as duas primeiras imagens (na parte superior) do filme de Mitevska que apresentamos neste segmento. A primeira delas (parte superior, à esquerda) mostra uma mulher com xale vermelho e com a cabeça coberta por um lenço branco sendo tentada por um demônio, o que nos remeteu à terceira imagem aqui apresentada (parte inferior, à esquerda), pintada nas paredes do mosteiro de Rila. Se, no jogo de linguagem da primeira imagem do filme, a mulher que está sendo seduzida pelo demônio, por estar resistindo à tentação, está ainda vestida, na terceira imagem, a cena já se passa no inferno, onde mulheres nuas com pernas acorrentadas e corpos envolvidos por serpentes, por não terem resistido à tentação de satanás, ardem em labaredas de fogo, sob a vigilância de seres diabólicos dotados de rabos e chifres. Tal como a terceira imagem, a segunda imagem do filme de Mitevska também retrata o inferno, com homens e mulheres em trajes profanos misturados a seres diabólicos com cabeças de serpente, todos sendo tragados pelas labaredas. Já a quarta imagem (parte inferior, à direita), intitulada Luxúria e dissolução carnal, foi extraída de um livro francês do século XV, intitulado O livro dos bons costumes, que circulou no Vale do Loire, por volta de 1490 e hoje pertencente ao acervo do Museu Condé (ms. 297, fol. 109v). No site onde foi publicada esta imagem, ela vem 
acompanhada da seguinte observação: "A mulher em seu banheiro ou tomando banho incorpora nos textos e na iconografia do período medieval a culpa, a ociosidade, a vaidade e, invariavelmente, uma forma de hipersexualidade condenável" que é atestada, é claro, pela presença da figura diabólica peluda e chifruda que se mostra por trás da mulher nua que acabou de sair do banho. As duas primeiras imagens são fotos feitas por Antonio Miguel de cenas do filme de Mitevska (2019). As fontes das demais imagens e informações são apresentadas a seguir. A foto do primeiro site abaixo foi tirada em 08 de julho de 2012 por Nickolay Stanev. A foto do segundo site é de autoria de Vika Bershadskaya. (https://br.pinterest.com/pin/14003448829387081/); (https://pt.wikipedia.org/wiki/Mosteiro_de_Rila); (http:// whc.unesco.org/pg.cfm?cid=31\&id_site=216); https://www.shutterstock.com/pt/image-photo/rila-bulgariajuly-8-scene-hell-painted$\underline{111691628)}$.

N79 - Conversa sobre os manaós, na casa grande, entre portugueses colonizadores, após o capitão Belchior anunciar o que ele supunha ser a rendição dos manaós, no filme de Caldeira (1977). O segmento fílmico no qual transcorre essa conversa é (0h30min11s a 0h31min45s).

N80 - Após o mergulho sem volta de Ajuricaba no Rio Negro do século 18, o filme de Caldeira (1977) retorna à Manaus de final da década de 1970, onde ocorre uma outra caça - agora feita por um policial anônimo, armado de metralhadora (mesmo ator que desempenhou anteriormente o papel do caçador português Belchior Mendes de Moraes) -, a de um outro rebelde anônimo (mesmo ator que desempenhou anteriormente o papel de Ajuricaba). Desta vez, porém, o rebelde, após ter conseguido escapar vivo navegando numa canoa pelo Rio Negro, é reencontrado, metralhado e morto, num estaleiro portuário às margens do rio. O seu corpo é, então, devolvido ao rio pelo policial que, com voz carregada de ódio e vingança, remete ao corpo rebelde que afunda no rio o mesmo desafio que Belchior gostaria de ter dirigido ao corpo metamórfico do manaó Ajuricaba. Esta cena transcorre no intervalo fílmico $(1 \mathrm{~h} 31 \mathrm{~min} 49 \mathrm{~s}$ até $1 \mathrm{~h} 32 \mathrm{~min} 00 \mathrm{~s})$.

N81 - Nesta cena do filme de Mitevska (2019), a conversa entre Petúnia e o policial Darko se passa numa sala da delegacia, separados um do outro por uma parede de vidro. A conversa adquire um tom intimista, o policial pega a mão de Petúnia e as mãos se correspondem entrelaçando-se com força num gesto sincero de afeto. Depois de uma pausa prolongada, a conversa prossegue em um tom confidencial. Nesta breve cena intimista e afetuosa, talvez a única do filme, Petúnia declara a Darko que não foi um pulo para competir. Não foi um pulo para desafiar ou desafiar-se, para provocar ou provocarse, contrariando o que ela mesma havia dito anteriormente ao policial. Foi como o pulo de um animal no rio. O pulo de Petúnia no rio foi um como se... um tropo de linguagem, uma fiçãa, um ato involuntário, irrefletido, irracional, casual, imprevisto, um como se o acaso... Não um pulo de Petúnia no rio, mas um pulo do rio em Petúnia. É como se o pulo dado no rio por alguém que não ela se tornasse o pulo dela. Só após ter o acaso consentido que seu corpo irrefletido fosse ferido por imprevistas vozes de humanos ferozes, Petúnia passa a se ver como um animal, uma presa do acaso... este animal feroz... 
N82 - Diferentemente das cenas finais do filme de Caldeira (1977), em que a narrativa se volta para a Manaus do final da década de 1970, e em que o olhar da câmera do cineasta se detém lentamente sobre alguns pontos da vida urbana da cidade que trazem à memória o nome de Ajuricaba - a placa indicativa do nome de uma rua, o nome de uma loja comercial etc. -, o brasão estampado sobre o fundo retangular em cor bege - que simboliza a cor das águas barrentas do rio Amazonas - da bandeira atual de Manaus, instituída em 20 de novembro de 2003 pela Lei Municipal de Manaus $n^{\circ} 718$, não apresenta qualquer rastro da memória dos manaós ou de seu líder Ajuricaba. De acordo com o artigo $2^{\circ}$ da Lei de 17 de abril de 1906, que instituiu o brasão tripartite inserido no pano retangular da bandeira, o segmento superior à esquerda mostra o encontro das águas dos rios Solimões e Negro, dois pequenos barcos a remo e o descobrimento da foz do rio Solimões pela expedição espanhola liderada pelo explorador, conquistador e corregedor Francisco de Orellana (1511-1546), em meados do século XVI (1542). Por sua vez, o segmento superior à direita mostra a fundação definitiva de Manaus, em princípios do século XVII. Nele, visualiza-se, no plano de fundo à esquerda, uma fortificação com uma bandeira portuguesa alçada no topo de um mastro e, no plano de fundo à direita, casas de palha representativas das primeiras construções da cidade. No plano de frente deste mesmo segmento, visualizase um colonizador português e uma indígena num aperto de mãos, simbolizando as pazes celebradas entre os índios e a metrópole pelo casamento de uma filha do cacique com o comandante da escola militar portuguesa. Já no segmento maior situado na parte inferior do brasão, visualiza-se um trecho de rio, tendo em relêvo, na frente, uma árvore simbólica da natureza agrícola e industrial da região que tornou Manaus o grande empório da goma elástica. É isso o que dizia a lei de 1906. E é isso também o que reafirmou a lei de 2003 e o Manual de Identidade Visual: Guia de Aplicação da Marca da Prefeitura Municipal de Manaus. Mas, sob uma perspectiva decolonial, o brasão da bandeira de Manaus poderia ser diversamente significado. Ali onde os rios Negro e Solimões se encontram, ambos perdem as suas identidades, tragadas que são pela oceânica identidade do Rio Amazonas. Ali onde há um pacífico aperto simbólico de mãos entre colonizador e colonizado, o que se pode ver, a rigor, não é senão a perda da identidade do colonizado, a perda de identidade de toda uma cidade que renega as raízes de seu próprio nome. É esta a leitura que faz o professor José Ribamar Bessa Freire da história de uma cidade cujo brasão simboliza, a rigor, a traição da sua memória: “A população atual de Manaus, como regra geral, reage indignada, quase com espírito corporativista, quando os seus visitantes manifestam-se agradavelmente surpresos por se encontrarem, apesar de tudo, diante de uma cidade marcadamente indígena, do ponto de vista histórico, cultural e ecológico. Ninguém quer se identificar hoje com os vencidos de ontem, porque isto implica assumir o fato de que Manaus é uma cidade derrotada. Derrotada e mal-amada. Mal-amada porque desconhecida. A “civilização de palha” erguida na Amazônia - resultado da experiência milenar e coletiva dos povos indígenas - faz parte de um passado que a ideologia dominante teima em considerar "atrasado", "bárbaro", e "não-histórico", embora ele tenha contribuído com soluções inteligentes e criativas nas várias formas de se aprimorar e de habitar o espaço amazônico. O espaço amazônico foi ocupado, hierarquizado e, portanto, humanizado pelos "povos-testemunhas" (Daniel Vidart) que aqui viveram antes da invasão do europeu. Mas esse fato é encoberto hoje pelos herdeiros dos conquistadores e 
desconhecido pelos descendentes dos conquistados. O resultado é a ruptura da continuidade espacial entre a sociedade mestiça em construção e o que havia anteriormente. Como consequência busca-se angustiadamente "no outro" a identidade perdida. Queima-se a "tapera dos Manaus" para construir a "Paris dos Trópicos" ou a "Miami brasileira", mesmo se esse processo é realizado em detrimento da qualidade de vida. O elo com o passado era de vidro e se quebrou" (FREIRE, 1987, p. 1-2).

Fontes: (https://pt.wikipedia.org/wiki/Bandeira_de_Manaus);

(https://pt.wikipedia.org/wiki/Brasão_de_Manaus);

(https://pt.wikipedia.org/wiki/Francisco_de_Orellana);

(http://www.manaus.am.gov.br/wp-content/uploads/2019/08/MIDPMM2019-19-

08.pdf).

N83 - A heráldica expansionista colonizadora europeia das terras de Abya Yala nada mais é senão um conjunto de jogos simbólico-memorialistas de linguagem de guerras imperialistas que se travaram, desde épocas pré-históricas, entre povos que habitaram as terras de Ásia, África e Europa. Tais jogos são, portanto, símbolos bélicos de poder, de dominação, de violência e de genocídio praticados pelos vencedores - no caso de nosso estudo, o colonizador europeu - contra os povos vencidos - no nosso caso, os povos ameríndios. Assim, do mesmo modo que seria impróprio falar-se, em nível global, numa heráldica dos derrotados, seria também impróprio falar-se, no caso do nosso estudo, numa beráldica ameríndia feminista e, particularmente, numa heráldica manaú amazônico-feminista. Ela, de fato, não existe e nunca existiu; mas seria, porém, possível imaginá-la, bem como tornála acessível à visão, isto é, inventar um jogo artístico-simbólico-visual de linguagem e fazêla dele participar. Entretanto, uma heráldica manaó amazônico-feminista não poderia simplesmente apagar a memória do colonizador-mercantilista-patriarcal-cristão, mas sim, decolonializar essa memória, isto é, desconstrui-la derridiana-antropofagicamente, o que significa comêla comendo a sua heráldica simbólico-aristocrática, degluti-la para nutrir-se imaginariamente da longevidade de sua potência e poder bélicos e invertê-los em favor dos povos colonializados em nome de qualquer causa ou preconceito, de modo que essa memória heráldica desconstruida, no caso particular de nosso estudo, passe a expressar visualmente a memória manaú amazônico-feminista do poder de resistência dos povos ameríndios e das feministas amazônicas. A segunda imagem por nós inventada que apresentamos neste segmento é a deste Brasão Decolonializado ou Desconstruído (BDD), construído tão somente com base numa analogia formal com a primeira imagem, a do Brasão do Estado do Amazonas (BEA), o qual, tal como o da cidade de Manaus, participa da mesma concepção simbólica da heráldica expansionista colonizadora europeia das terras de Abya Yala. Na sequência, descrevemos as mutações operadas no BEA de modo a se obter o BDD. No $\mathrm{BEA}$, as três imagens que aparecem no interior elíptico trissecionado em duas seções azuis, simbolizando o céu, e uma em verde, simbolizando as florestas - as duas setas e as duas penas entrelaçadas e cruzadas, representativas da civilização moderna; o barrete frígio (touca vermelha na parte azul superior), simbolizando a lealdade à forma republicana de governo; a estrela amarela, na parte maior, simbolizando a paz e o progresso -, foram substituídas, no BDD, por imagens da face de Ajuricaba, da face pintada ao modo indígena de Petúnia e pela imagem inscrita num vaso ateniense (cerca de 420 a.C.) de uma amazona cavalgando em roupas do povo cita. À direita, no BDD, a cópia feita por Fídias da escultura orginal 
de uma amazona portando um arco e, a tiracolo, um recipiente para flechas em forma de chifre, pertencente ao acervo dos museus capitolinos de Roma, substitui o símbolo representativo da indústria, na mesma posição, ao lado direito, no BEA. A introdução de seres humanos ou de seres mitológicos com forma humana no BEA representa uma primeira transgressão nos jogos simbólico-memorialistas de linguagem reprodutores da heráldica expansionista colonizadora europeia, uma vez que tais jogos tendem a fazer uso exclusivo de elementos simbólicos representativos da riqueza e do progresso de uma nação, quer dando-se destaque a elementos geográfico-naturalísticos potencialmente indutores de desenvolvimento econômico - rios, florestas, fauna, flora, montanhas, minérios, campos de atividade humana etc. -, quer dando-se destaque a elementos políticos, cívicos, militares, jurídicos, profissionais, religiosos etc., representativos das formas de governo, do poder, da ideologia, das instituições etc. A segunda transgressão é que não apenas humanizamos os símbolos da heráldica colonialista. Ao introduzirmos as imagens de Ajuricaba e de Petúnia no BDD, estamos explicitamente afrontando os valores mercantilistas, expansionistas, belicistas, cristãos, patriarcais, machistas, misóginos e racistas do colonizador europeu. O mesmo ocorre com a introdução das amazonas; da substituição da âncora pelo símbolo do movimento feminista amazônico, na base dos brasões; e da substituição da fênix pela imagem de uma serpente, no topo dos brasões. A introdução das amazonas trazem à memória a resistência que mulheres indígenas nativas impuseram à expedição comandada pelo conquistador Francisco de Orellana, século XVI, ao longo do rio Amazonas, durante a colonização espanhola do Perú, do genocídio dos Incas etc. Foi essa resistência feminina que levou Orellana a compará-las com as mulheres guerreiras amazônicas citas - um povo de pastores nômades equestres que habitaram a região denominada Cítia que, atualmente, constitui parte do território da Ucrânia e parte do território da Rússia - mencionadas na mitologia grega. Ironicamente, deve-se, portanto, ao próprio colonizador a perpetuação da memória dessas mulheres amazônicas guerreiras citas e, por extensão, das mulheres guerreiras ameríndias com as quais Orellana se defrontou, através do uso do nome a elas dado pelos gregos antigos, para nomear o rio Amazonas e o Estado brasileiro do Amazonas. Assim, os rastros ameríndios da resistência amazônico-feminina ao empreendimento colonialista europeu estão presentes nas raízes etimológicas da palavra iraniana Amazon, que remetem aos significados: lutar juntos, guerreiros, fazer a guerra. O campo semântico decolonialista no qual a palavra amaz̧onas está envolvida inspirou a constituição de um campo atual do movimento feminista autodenominado feminismo amazona, cujo propósito diferencial é o de se lutar pela igualdade de gênero dando-se um particular destaque às competências físicas femininas, sobretudo nas atividade esportivas e nas artes marciais, bem como às atividades literárias, cinematográficas e artísticas em geral que constróem a imagem da mulher guerreira, da mulher heroína. Entretanto, as concepções de heroísmo e de belicismo mobilizadas por essa vertente de feminismo opõem-se às imagens masculinas, machistas, imperialistas e violentas que orientaram e continuam orientando as práticas bélicas quentes ou frias de todos os tempos. Já a águia amazonense do BEA - significando o poder de uma coletividade - foi substituída por uma fênix e deslocada, no BDD, para cima do espelho de Vênus com pulso cerrado voltado para cima, isto é, do símbolo astrológico do planeta Vênus, ressignificado como símbolo representativo do feminismo amazona. A imagem da fênix renascendo extraída do Bestiário de Aberdeen - um texto manuscrito ilustrado que começou 
a circular na Inglaterra, por volta do ano de 1200, que se caracteriza pela descrição humorística e fantasiosa de todos os tipos de seres, reais ou fabulosos, acompanhados de comentários moralizantes, - potencializa o poder do movimento feminista, dado ser a fênix uma ave da mitologia grega dotada do poder de renascer de suas próprias cinzas, mesmo após um tempo bastante elástico de ter entrado em autocombustão. No nosso BDD, a fênix simboliza, então, o renascimento da resistência e da luta das mulheres, bem como dos valores das comunidades indígenas ameríndias das terras de Abya Yala, hoje conhecidas como América do Sul, bem como o renascimento da memória feminina da extinta comunidade manaó, a mãe dos deuses que deu à luz o nome atual da cidade de Manaus, capital do Estado do Amazonas. Quanto à crítica manifesta aos valores do cristianismo católico-romano e católico-ortodoxo mobilizada pela presença de uma serpente ironicamente alçada ao topo do nosso BDD, nós já o fizemos em notas a outros segmentos deste texto. Finalmente, decidimos também retirar o símbolo representativo do comércio e da agricultura, situado à esquerda no BEA, substituindo-o por dois pingentes de ramos da árvore tília, acrescentados como adornos a cada um dos colares de ramos de trigo, um à direita e o outro à esquerda, no BDD. No BEA, o símbolo representativo do comércio e da agricultura é uma cornucópia que remete à deusa romana da Fortuna e, portanto, ao desejo de fartura e prosperidade material. Já os ramos de tília eram utilizados pelos líderes religiosos da sociedade cita - denominados enarei - para preverem o futuro. Eles eram, portanto, vistos como profetas por seu povo. Heródoto, por sua vez, na sua História, deunos a conhecer um costume prevalecente entre os enarei, qual seja, o de se vestirem com roupas de mulheres, costume este que, segundo o patriarca da história, havia deixado os seus rastros no significado literal da própria palavra composta enarei (ena-rel), isto é, homemmulher. Seguem as fontes das informações e das imagens que manipulamos neste segmento para inventar o nosso Brasão Decolonial Desconstruído.

(https://brasao.org/brasao-do-estado-do-amazonas/);

(https://pt.wikipedia.org/wiki/Brasão_do_Amazonas);

(http://www.amazonas.am.gov.br/o-amazonas/simbolos/);

(https://pt.wikipedia.org/wiki/Rio_Amazonas);

(https://pt.wikipedia.org/wiki/Amazonas_(mitologia))

(https://pt.wikipedia.org/wiki/Mulheres_guerreiras_na_cultura);

(https://pt.wikipedia.org/wiki/Feminismo_amazona);

(https://azmina.com.br/reportagens/simbolos-do-feminismo-quais-sao-e-o-que-

significam/);

(https://pt.wikipedia.org/wiki/Citas);

(https://pt.wikipedia.org/wiki/Religião_cita);

(https://br.pinterest.com/pin/404127766567394719/);

(https://pt.wikipedia.org/wiki/Fénix);

(https://pt.wikipedia.org/wiki/Bestiário_de_Aberdeen).

N84 - Manchete da edição eletrônica de 17 de setembro de 2020 do INFOBAE, um jornal diário digital argentino criado em 2002 pelo empresário Daniel Hadad). Segue um trecho da matéria: "Indígenas de la comunidad Misak tumbaron este miércoles una estatua del conquistador español Sebastián de Belalcázar en Popayán, capital del convulso departamento colombiano del Cauca (suroeste), como forma de "reinvidicar la memoria 
de ancestros asesinados y esclavizados por las élites". "De Belalcázar fue un genocida que masacró a los pueblos que conquistó. Mi respeto a los Misak que hoy reivindican sus muertos. Al suelo un símbolo de 500 años de esclavitud”, afirmó la presidenta del Movimiento Alternativo Indígena y Social (Mais), Martha Peralta, en Twitter. Sebastián de Belalcázar, nacido en 1480 en lo que es la actual provincia española de Córdoba, fue un conquistador que fundó Quitó el 6 de diciembre de 1534, así como las localidades colombianas de Cali, Popayán y Belálcazar. "Cae un símbolo de 500 años de humillación y dominación a los pueblos originarios. Mis respetos para los hermanos y hermanas Misak. Como Estado pluriétnico y multicultural otras simbologías deben florecer y adornar el paisaje libertario", dijo, por su parte, el senador indígena Feliciano Valencia. La situación ocurrida en Popayán recuerda lo sucedido en los últimos meses en EE.UU., donde tras la muerte de George Floyd a manos de un policía blanco se multiplicaron los ataques a monumentos de líderes de la Confederación, padres fundadores y de exploradores vinculados a la "conquista" de América. Estos personajes son percibidos como símbolos del racismo por los manifestantes estadounidenses" (INFOBAE COLOMBIA, 2020).

N85 - Manchete da edição eletrônica de 05 de julho de 2020 do INFOBAE (Diário digital argentino criado em 2002 pelo empresário Daniel Hadad). Segue um trecho da matéria: "Un grupo de manifestantes derribó este sábado una estatua de Cristóbal Colón en la ciudad de Baltimore, en la costa este de Estados Unidos, en un nuevo episodio de la ola de ataques contra monumentos o estatuas de personajes históricos vinculados a la esclavitud y el colonialismo.[...] En otros países, particularmente en el Reino Unido, también se produjeron actos similares. Varias estatuas de Cristóbal Colón fueron derribadas o dañadas, particularmente en Boston, Miami, Richmond y Camden. Por su parte, la municipalidad de San Francisco retiró una estatua del explorador genovés de la sede del parlamento local, y el alcalde de Newark (Nueva Jersey) retiró otra estatua del parque porque representa un "símbolo de opresión y de supremacismo blanco", según afirmó el alcalde Ras Baraka" (INFOBAE EEUU, 2020).

\section{Referências}

ALBERT, Bruce. O ouro canibal e a queda do céu: uma crítica xamânica da economia politica da natureza. Brasilia: UnB, 1995. (Série Antropologia, 174).

BRANDT MEIO AMBIENTE. Relatório de Impacto Ambiental (RIMA) emitido pela Secretaria de Estado de Meio Ambiente (SEMA) do Estado do Pará (PA) sobre o Projeto Volta Grande elaborado pela empresa Belo Sun Mineração Ltda. Março de 2012. Disponível em: < https://www.semas.pa.gov.br/download/2BSML001-1-EA-RIM0002_RIMA_REVISADO.pdf $>$. Acesso em: 20 set. 2020.

CALDEIRA, Oswaldo. Ajuricaba, o rebelde da Amazônia. 1977. Filme longametragem. Produtora e Distribuidora: Embrafilme. Gênero: drama. Duração: 105 minutos. Direção: Oswaldo Caldeira. Roteiro: Oswaldo Caldeira e Almir Muniz. Música: Ayrton Barbosa. 
CASA FIAT DE CULTURA. A arte nos mapas nas casas fiat de cultura: uma viagem pelos quatros cantos do mundo. Nova Linma: Casa Fiat de Cultura, 2008.

DE THEIJE, Marjo. Ouro e Deus: sobre a relação entre prosperidade, moralidade e religião nos campos de ouro do Suriname. Religião e Sociedade, Rio de Janeiro, v. 28, n. 1, p. 69-83, julho de 2008.

FRAZER, James. G. O ramo dourado. Prefácio de Darcy Ribeiro. Introdução de Mary Douglas. Tradução Waltensir Dutra. Rio de Janeiro: Zahar Editores, 1982.

FREIRE, José R. B. Barés, Manaos, Tarumãs: o processo histórico da urbanização de Manaus. Revista Arquitetura e Urbanismo, São Paulo, v. ano 3, n.10, fev./mar., p. 5360, 1987. Disponível em:

< https://edoc.ufam.edu.br/bitstream/123456789/2170/1/Anexo $\% 20 \mathrm{~A} \% 20$ \%201987\%20Barés\%20Manaós\%20Tarumãs \%20\%28JRBessaFreire\%29.pdf > . Acesso em: 21 jul. 2020:

FRIEDE, Juan. Los Chibchas bajo la dominación española. Bogotá: La Carreta. 1974.

FUNDACIÓN GAIA AMAZONAS. Salvaguarda del patrimonio cultural inmaterial del noroeste amazónico. Iniciativa binacional entre Colombia y Brasil. Cartografia de los sitios sagrados. Ministerio de la Cultura Nacional de Colômbia y Instituto do Patrimônio Histórico e Artistico Binacional y Ministério da Cultura do Brasil, 2014.

GLOCK, Hans-Johann. Dicionário Wittgenstein. Trad. Helena Martins. Rio de Janeiro: Zahar, 1998.

GUSMÁN, Décio. M. A. A. História de Brancos: memória, historiografia dos indios mano do Rio Negro (século XVIII-XX). 1997. Dissertação (Mestrado em Anstropologia), 175p. Instituto de Filosofia e Ciências Humanas, Universidade Estadual de Campinas. Campinas, 1997.

INFOBAE COLOMBIA. Indigenas tumbaron la estatua del conquistador español Sebastián de Belalcázar en el suroeste de Colombia. Matéria publicada pela edição eletrônica de 17 de setembro de 2020 do jornal eletrônico diário "INFOBAE". Disponível em: < https://www.infobae.com/america/colombia/2020/09/17/indigenastumbaron-la-estatua-del-conquistador-espanol-sebastian-de-belalcazar-en-el-suroeste-decolombia/>. Acesso em: 12 out. 2020:

INFOBAE EEUU. Manifestantes derribaron otra estatua de Cristóbal Colón en Baltimore. Matéria da edição eletrônica de 05 de julho de 2020 do INFOBAE, publicada em 05 de julho de 2020: Disponível em: 
< https://www.infobae.com/america/eeuu/2020/07/05/manifestantes-derribaron-otraestatua-de-cristobal-colon-en-baltimore/>. Acesso em: 12 out. 2020

LÉVI-STRAUSS, Claude. As Estruturas elementares do parentesco. Tradução de Mariano Ferreira. Petrópolis, Vozes, 1982.

MARTINS, Rui. Filme ridiculariza o machismo católico ortodoxo na Macedônia. Jornal Opção, Goiânia, 11 fev. 2019. Disponível em:

$<\underline{\text { https:// www.jornalopcao.com.br/ultimas-noticias/filme-ridiculariza-o-machismo- }}$ catolico-ortodoxo-na-macedonia-163980/>. Acesso em: 08 jul. 2020:

MITEVSKA, Teona S. Deus é mulher e seu nome é Petúnia. Filme longa-metragem. Duração: 100 minutos. Distribuidora no Brasil: Pandora Filmes, 2019.

NEWTON, Isaac. General Scholium (1729). Tradução de Andrew Motte disponível nos sites seguintes,: < https://isaacnewton.ca/newtons-general-scholium/);

$<$ https://newtonprojectca.files.wordpress.com/2013/06/newton-general-scholium1729-english-text-by-motte-a4.pdf > . Acessos em: 05 jan. 2021

OVÍDIO. Metamorfoses. São Paulo: Madras Editora Ltda, 2003.

PEREIRA, José C. O paradoxo da cruz: o diabólico e o simbólico: um estudo da teologia da cruz. São Paulo: Arte \& Ciência, 2002.

PNCSA. Projeto Nova Cartografia Social da Amazônia. Boletim número 12 intitulado "Povos e Comunidades Tradicionais da Volta Grande do Xingu Garimpeiros, Agricultores, Assentados, Indígenas, Pescadores e Moradores PNCSA/Cartografia da Cartografia Social na Vila Ressaca 04/07/2018”. Matéria postada no site seguinte em 12 de julho de 2018. Disponível em:

$<\underline{\text { http:/ / novacartografiasocial.com.br/volta-grande-do-xingu-lancamento-do-boletim- }}$ no-12-povos-e-comunidades-tradicionais-da-volta-grande-do-xingu-garimpeirosagricultores-assentados-indigenas-pescadores-e-moradores-pncsa-ca/>. Acesso em: 20 set. 2020

PONCE, Aníbal. Educação e luta de classes. 4. ed. Tradução de José Severo de Camargo Pereira. São Paulo: Cortez: Autores Associados, 1983.

RAMÓN, Paula. Eldorado trágico: os caminhos violentos do garimpo no país de Maduro. Revista Piauí, Teresina, n. 159, dez. 2019. Disponível em: < https://www.amazoniasocioambiental.org/pt-br/radar/eldorado-tragico/>. Acesso em: 20 ago 2020:

RAMOS, Alcida R. Ouro, Sangue e lágrimas na amazônia: dos conquistadores aos Yanomami. Série Antropologia, Brasília, v. 438, 2012, p. 6-22. 
RIBEIRO, Maria G. Imaginário da serpente de A a Z. Campina Grande: Eduepb, 2017.

RISTINE, Jennifer. "Madalena era uma mulher rica, não uma prostituta". Entrevista concedida por Ristini à jornalista Patricia R. Blanco. E1 País Brasil, 03 ago. 2018.

Disponível em:

<https://brasil.elpais.com/brasil/2018/08/02/cultura/1533237261_768771.html>. Acesso em: 24 jul. de 2020

SLATER, Candace. All That Glitters: Contemporary Amazonian Gold Miners' Tales. Comparative Studies in Society and History, Michigan (USA), v. 36, n. 4, p. 720-742, oct. 1994.

SILVA, Elielson. Entrevista para o jornal “Amazônia Notícia e Informação”, publicada em 02 de outubro de 2019. Disponível em: < https://amazonia.org.br/2019/10/belomonte-e-belo-sun-o-desenvolvimentismo-triunfalista-e-violento-que-afunda-a-regiaoamazonica-em-degradacoes-entrevista-especial-com-elielson-silva/>. Acesso em 20 set. 2020

SOUSA, Rainer G. A prostituição na Antiguidade. s/d-1. Blog "História do mundo". Disponível em: < https://www.historiadomundo.com.br/idade-media/a-prostituicao-naidade-media.htm $>$. Acesso em: 24 jun. 2020.

VILAR, Leandro. Cristianismo Copta. 2012. Texto não paginado postado pelo autor em seu blog abaixo discrimindado, intitulado "Seguindo os passos da História", em 22 de maio de 2012: (http://seguindopassoshistoria.blogspot.com/2012/05/cristianismocopta.html). e Acesso 07 jul. 2020

WITTGENSTEIN, Ludwig. Cultura e valor. Tradução Jorge Mendes. Lisboa: Edições $70,2000$.

. Gramática filosófica. Tradução Luís Carlos Borges. São Paulo: Edições

Loyola, 2003.

Observações filosóficas. Tradução Adail Sobral e Maia Stela Gonçalves. São Paulo: Edições Loyola, 2005.

Observações sobre “O Ramo Dourado” de Frazer. Trad. João José R. L. de Almeida. Porto: Deriva Editores, 2011.

Da certeza. Tradução de Maria Elisa Costa. Revisão e Introdução de Sérgio Miranda. Lisboa: Edições 70, 2012.

Investigações filosóficas/Philosophische untersuchungen. Edição bilingue alemão/português. (João J. R. L. de Almeida, Apontamentos, Tradução e Notas). Wittgenstein Translations, s/d. Disponível em: < http://www.psicanaliseefilosofia.com.br/textos/>. Acesso em 20 out. 2020 